Supporting Information for

\title{
Reagent Controlled Direct Dehydrative Glycosylation with 2-Deoxy Sugars: Construction of the Saquayamycin Z Pentasaccharide
}

\author{
J. Colin Mizia, Clay S. Bennett \\ Department of Chemistry, Tufts University, 62 Talbot Ave., Medford, MA 02155, United States
}

Table of Contents

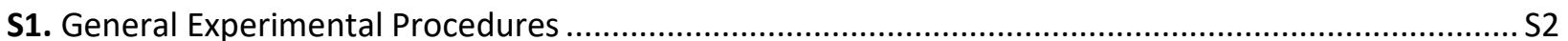

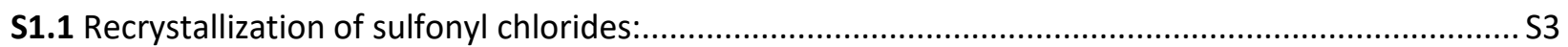

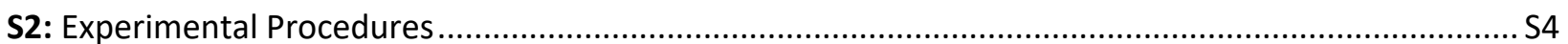

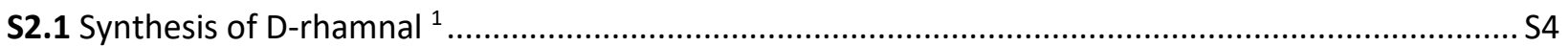

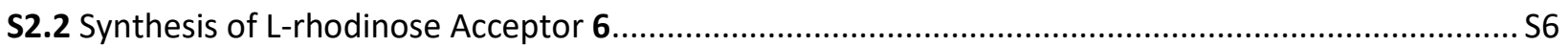

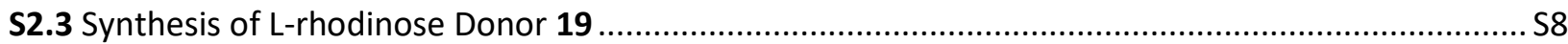

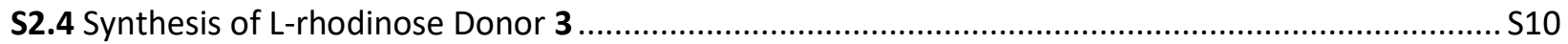

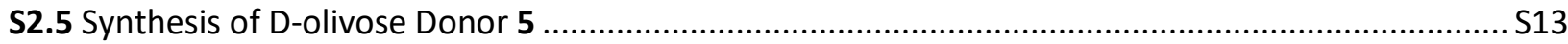

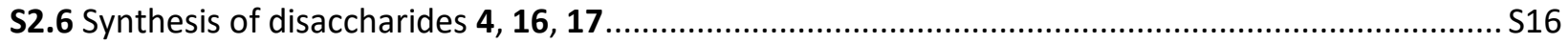

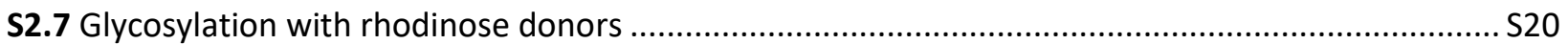

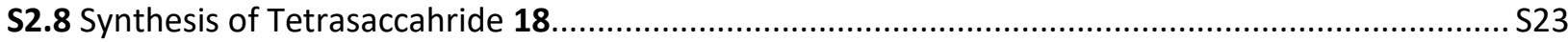

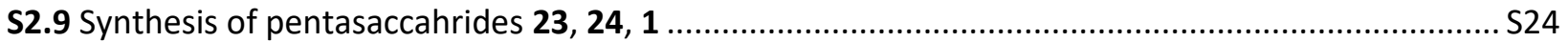

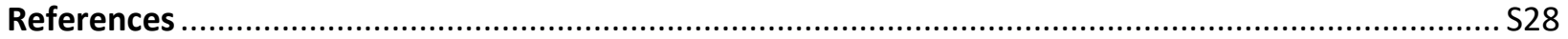

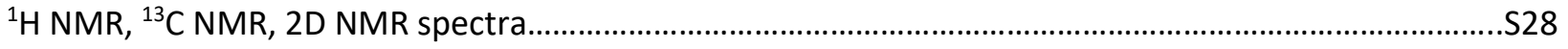


S1. General Experimental Procedures:

Prior to running the glycosylation reactions, all solid reagents were dried by azeotropic removal of water using toluene and a rotary evaporator then set under reduced pressure $16 \mathrm{~h}$ before use. All reactions were performed under inert argon atmosphere, unless otherwise noted.

Solvents for reactions were dried through a commercial solvent purification system immediately prior to use. All other chemicals were purchased at the highest possible quality and used as received, except where noted. Flash column chromatography was performed on 230-400 mesh silica gel. Analytical and preparative thin layer chromatography was carried out on silica gel 60 F-254 plates. Products were visualized using UV or by staining with either $5 \%$ aqueous sulfuric acid or ceric ammonium molybdate. NMR spectra were recorded on an NMR spectrometer at $500 \mathrm{MHz}$ for ${ }^{1} \mathrm{H}$ NMR and $125 \mathrm{MHz}$ for ${ }^{13} \mathrm{C}$ NMR. Chemical shifts are reported in ppm relative to $\mathrm{TMS}$ (for $1 \mathrm{H} \mathrm{NMR} \mathrm{in} \mathrm{CDCl}_{3}$ ) or $\mathrm{CDCl}_{3}$ (for $13 \mathrm{C} \mathrm{NMR} \mathrm{in} \mathrm{CDCl} 3$ ). For $1 \mathrm{H} \mathrm{NMR}$ spectra, data are reported as follows: $\delta$ shift, multiplicity $(s=$ singlet, $m=$ multiplet, $t=$ triplet, $d$ = doublet, $\mathrm{q}=$ quartet, $\mathrm{dd}=$ doublet of doublets, $\mathrm{dq}=$ doublet of quartets, $\mathrm{ddd}=$ doublet of doublet of doublets), coupling constants are reported in $\mathrm{Hz}$. Low resolution mass spectra (LRMS) were recorded using an ESI-MS with an additional APCI source.

High-resolution mass spectra (HRMS) were obtained on ElectroSpray lonization (ESI) on a Waters Qtof Premier instrument in the positive mode or Fourier Transform Ion Cyclotron Resonance Mass Spectrometer (FTICR-MS) with direct analysis in real time (DART) ionization source.

Optical rotations were measured at $589 \mathrm{~nm}$ in a $5 \mathrm{~cm}$ cell at room temperature.

Abbreviations:

DTBMP: 2,6-di-tert-butyl-4-methyl-pyridine

DMAP: N,N-dimethyl-4-aminopyridine

DMF: $\mathrm{N}, \mathrm{N}$,-dimethylformamide

KHMDS: potassium hexamethyldisilazide

NapBr: 2-(bromomethyl)naphthalene

TBAI: tetrabutylammonium iodide

THF: tetrahydrofuran

TTBP: 2,4,6-tri-tert-butylpyrimidine

TrisylCl: Trisyl chloride (2,4,6-tri-isopropylbenzenesulfonyl chloride)

$\mathrm{TsCl}$ : Tosyl chloride (4-methylbenzenesulfonyl chloride) 
S1.1 Recrystallization of sulfonyl chlorides:

S1.1.1 Recrystallization of tosyl chloride

A solution of tosyl chloride $(50 \mathrm{~g})$ in diethyl ether $(400 \mathrm{~mL})$ was washed twice with aqueous $2 \mathrm{M}$ $\mathrm{NaOH}\left(2 \times 100 \mathrm{~mL}\right.$ ), then dried over $\mathrm{Na}_{2} \mathrm{SO}_{4}$, and filtered. The receiving flask was covered with parafilm and placed in a crystalizing dish. The crystalizing dish was packed with powdered dry ice, and the flask left there for at least $4 \mathrm{~h}$, refreshing dry ice as needed. The resulting colorless crystals were filtered then placed under vacuum overnight. The recrystallized material should be stored in the dark in a sealed container that had been purged with argon.

\section{S1.1.2 Recrystallization of trisyl chloride}

Trisyl chloride $(5 \mathrm{~g})$ was dissolved in $20 \mathrm{~mL}$ of anhydrous pentane by heating, then allowed to cool to room temperature and left to crystalize for at least three hours. The resulting crystals were filtered and dried undere vacuum overnight. The recrystallized material should be stored in the dark in a sealed container that had been purged with argon. 


\section{S2: Experimental Procedures}

S2.1 Synthesis of D-rhamnal ${ }^{1}$

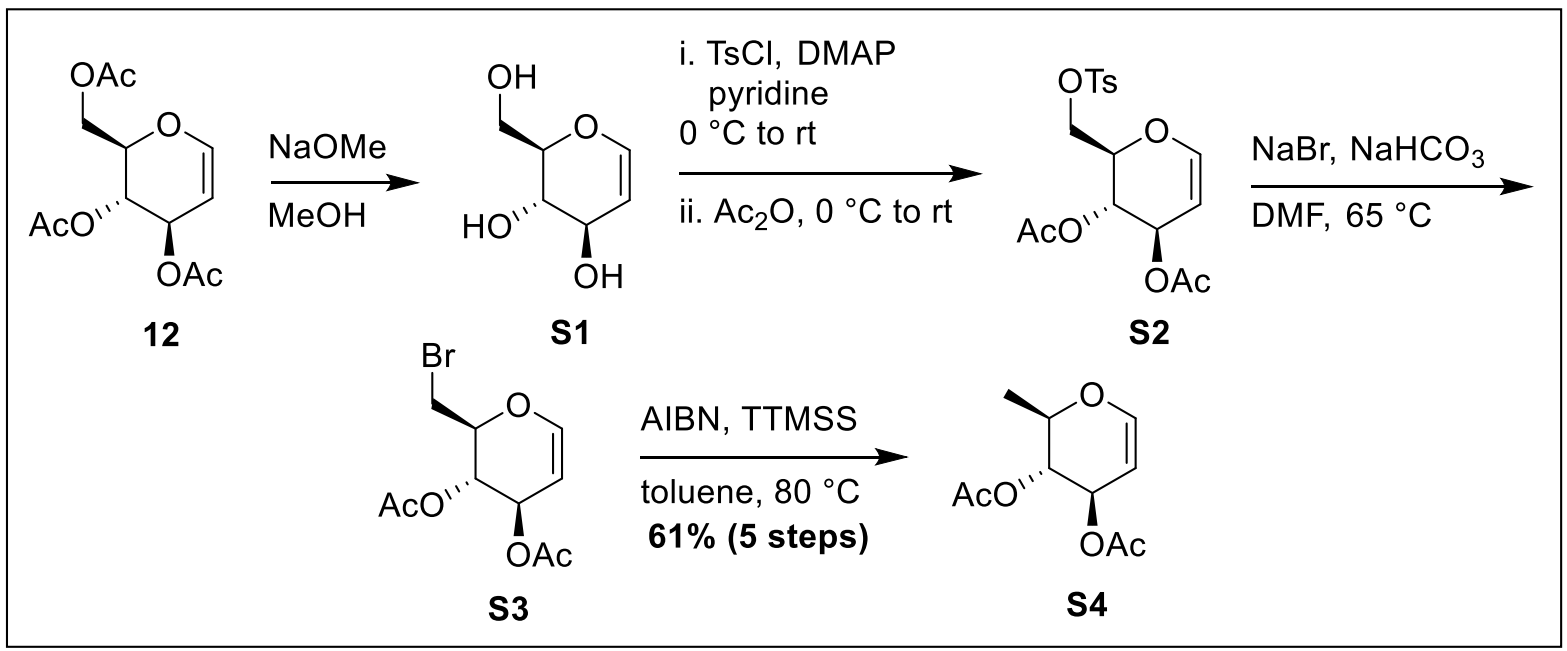

Synthesis of D-rhamnal was adapted from a procedure by Tanaka et al. ${ }^{1}$ Tri-O-acetyl-D-glucal 12 ( $40 \mathrm{~g}, 146.91 \mathrm{mmol}$ ) was dissolved in $120 \mathrm{~mL}$ methanol. Sodium methoxide $(3.28 \mathrm{~g}, 44.1 \mathrm{mmol})$ was added as a solid and the reaction was stirred at room temperature. After 30 minutes, the solvent was removed under reduced pressure to afford a thick syrup. The crude was purified by flash chromatography (5\% to $30 \%$ methanol:dichloromethane) and dried on high vacuum overnight while stirring to afford D-glucal S1 $(20.1 \mathrm{~g}, 95 \%)$ as a white solid.

The resulting D-glucal was dissolved in pyridine $(452 \mathrm{~mL})$ with DMAP $(0.840 \mathrm{~g}, 6.85 \mathrm{mmol})$ and cooled to $0{ }^{\circ} \mathrm{C}$. Recrystallized tosyl chloride was added as a solid and the reaction was stirred $0{ }^{\circ} \mathrm{C}$ to rt. After three hours, the reaction was again cooled to $0{ }^{\circ} \mathrm{C}$ and acetic anhydride $(77.7 \mathrm{~mL}, 853 \mathrm{mmol})$ was added in four portions. The reaction was stirred $0{ }^{\circ} \mathrm{C}$ to $\mathrm{rt}$. After two hours, the reaction was quenched by pouring over saturate sodium bicarbonate $(\sim 1 \mathrm{~L})$. After gas evolution ceased, the solution was extracted with ethyl acetate $(5 \times 300 \mathrm{~mL})$. The combined organic layers were washed with $1 \mathrm{M}$ hydrochloric acid $(1 \times 750 \mathrm{~mL})$, saturated sodium bicarbonate $(1 \times 500 \mathrm{~mL})$, and brine $(1 \times 500 \mathrm{~mL})$. The organic layer was then dried with sodium sulfate, filtered through cotton, and the solvent removed under reduced pressure.

The resulting crude mixture of $\mathbf{S} 2$ was dissolved in DMF $(500 \mathrm{~mL})$ with sodium bromide $(70.3 \mathrm{~g}$, $683 \mathrm{mmol}$ ) and sodium bicarbonate $(34.4 \mathrm{~g}, 410 \mathrm{mmol})$. While stirring vigorously, the reaction was heated to $65^{\circ} \mathrm{C}$ under a reflux condenser. After 16 hours, the reaction was cooled to room temperature and poured over water $(\sim 750 \mathrm{~mL})$. The mixture was extracted with ethyl acetate $(5 \times 300 \mathrm{~mL})$ and the combined organic layers were washed with water $(6 \times 250 \mathrm{~mL})$ then brine $(2 \times 250 \mathrm{~mL})$. The organic layer was dried over sodium sulfate, filtered through cotton, and the solvent removed under reduced pressure.

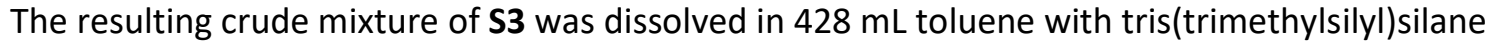
$(27.23 \mathrm{~g}, 109.6 \mathrm{mmol})$ and AIBN $(4.49 \mathrm{~g}, 27.4 \mathrm{mmol})$. The mixture was then stirred at $80^{\circ} \mathrm{C}$ under a reflux condenser. After 20 hours the solvent was removed under reduced pressure and the crude mixture purified by flash chromatography ( $5 \%$ to $10 \%$ ethyl acetate: hexanes) to afford 3,4-di-O-acetylD-rhamnal S4 (17.75 g, 60.0\%) as a slightly yellow oil. Spectroscopic data was in agreement with previously reported data. ${ }^{1}$ 
${ }^{1} \mathrm{H}$ NMR $(500 \mathrm{MHz}$, Chloroform-d) $\delta 6.43(\mathrm{dd}, J=6.1,1.5 \mathrm{~Hz}, 1 \mathrm{H}), 5.37-5.31(\mathrm{~m}, 1 \mathrm{H}), 5.03(\mathrm{dd}, J=8.2,6.1 \mathrm{~Hz}, 1 \mathrm{H})$, $4.78(\mathrm{dd}, J=6.1,3.0 \mathrm{~Hz}, 1 \mathrm{H}), 4.11(\mathrm{dq}, J=8.2,6.6 \mathrm{~Hz}, 1 \mathrm{H}), 2.09(\mathrm{~s}, 3 \mathrm{H}), 2.05(\mathrm{~s}, 3 \mathrm{H}), 1.31(\mathrm{~d}, J=6.6 \mathrm{~Hz}, 3 \mathrm{H})$.

${ }^{13} \mathrm{C}$ NMR $\left(126 \mathrm{MHz}^{\mathrm{CDCl}} 3\right) \delta 170.78,170.04,146.13,98.93,72.68,72.01,68.46,21.21,21.03,16.70$. 


\section{S2.2 Synthesis of L-rhodinose Acceptor 6}
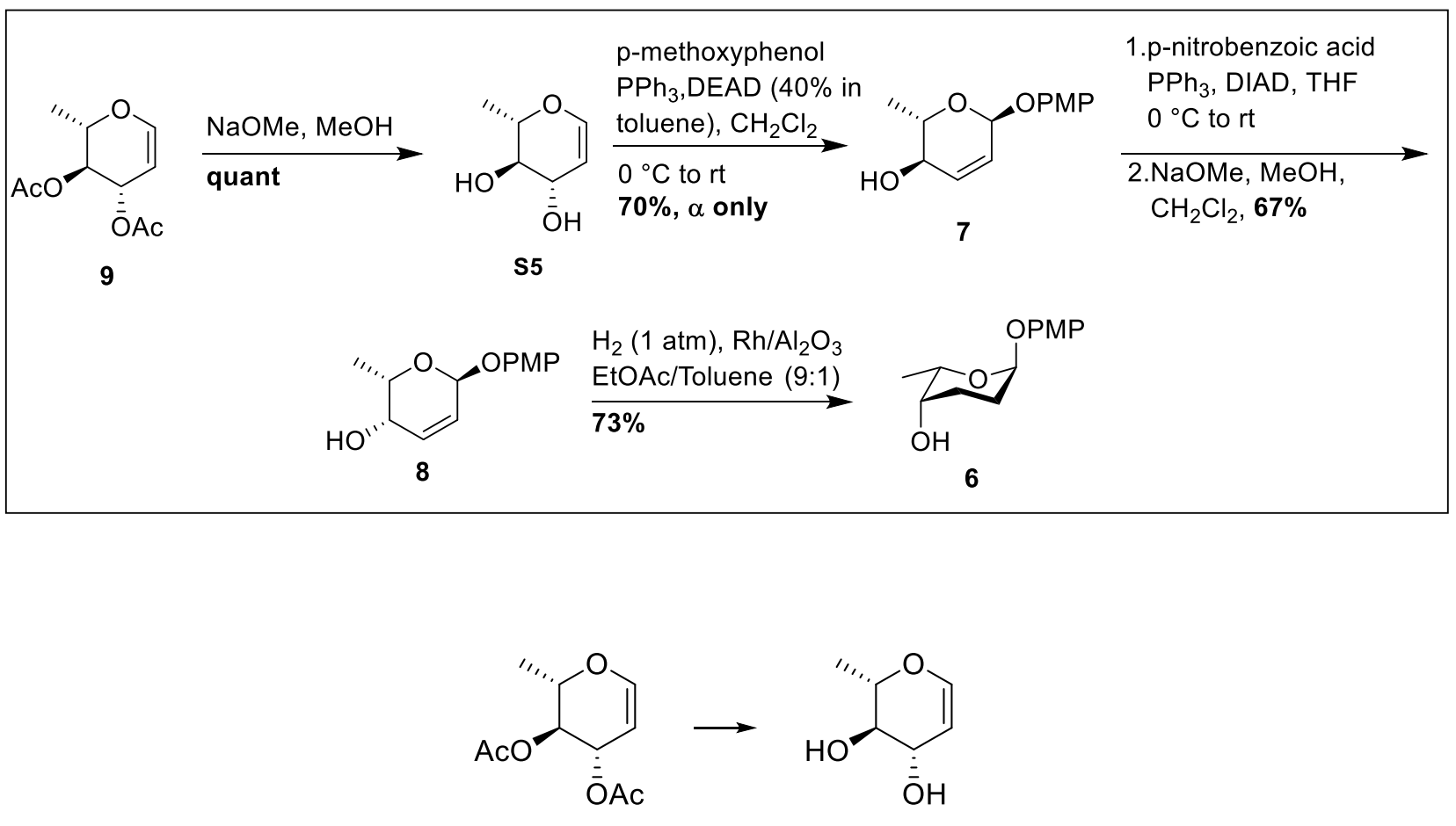

9

S5

L-rhamnal (S5) 3,4-di-O-acetyl-L-rhamnal (9) (10.00g, $46.74 \mathrm{mmol}$ ) was dissolved in $77 \mathrm{~mL}$ $\mathrm{MeOH}$. Sodium methoxide $(758 \mathrm{mg}, 14.0 \mathrm{mmol}$ ) was added as a solid and the solution was allowed to stir at room temperature. After one hour, the solvent was removed under reduced pressure. The resulting crude mixture was purified by flash chromatography $\left(10 \% \mathrm{MeOH}: \mathrm{CH}_{2} \mathrm{Cl}_{2}\right)$ to afford compound S5 as a white solid $\left(6.1 \mathrm{~g}\right.$, quantitative yield). ${ }^{1} \mathrm{H}$ and ${ }^{13} \mathrm{C}$ NMR were in agreement with previously reported data. ${ }^{2}$

${ }^{1} \mathrm{H}$ NMR $(500 \mathrm{MHz}$, Chloroform-d) $\delta 6.32$ (dd, $J=6.0,1.8 \mathrm{~Hz}, 1 \mathrm{H}), 4.71$ (dd, $J=6.0,2.1 \mathrm{~Hz}, 1 \mathrm{H}$ ), $4.25-$ $4.18(\mathrm{~m}, 1 \mathrm{H}), 3.86(\mathrm{dq}, J=9.8,6.3 \mathrm{~Hz}, 1 \mathrm{H}), 3.42(\mathrm{ddd}, J=10.4,7.3,3.8 \mathrm{~Hz}, 1 \mathrm{H}), 3.08-2.92(\mathrm{~m}, 1 \mathrm{H}), 2.60-$ $2.36(\mathrm{~m}, 1 \mathrm{H}), 1.39(\mathrm{~d}, J=6.3 \mathrm{~Hz}, 3 \mathrm{H})$.

${ }^{13} \mathrm{C}$ NMR $\left(126 \mathrm{MHz}, \mathrm{CDCl}_{3}\right) \delta 145.00,102.81,75.62,74.59,70.52,17.30$.<smiles>C[C@@H]1OC=C[C@@H](O)[C@@H]1O[Na]</smiles>

p-methoxyphenyl 2,3,6-trideoxy- $\alpha$-L-erythro-hex-2-enepyranoside. Compound 3 was prepared according to a procedure published by Sulikowski. ${ }^{3}$ A flame dried flask was charged with triphenylphosphine (13.6g, $51.6 \mathrm{mmol})$ and $p$-methoxyphenol $(6.99 \mathrm{~g}, 56.3 \mathrm{mmol})$. $\mathbf{S 5}$ (6.08g, $46.7 \mathrm{mmol})$ was dissolved in dry dichloromethane $(141 \mathrm{~mL})$ and transferred into the reaction flask via cannula. The 
solution was cooled to $0{ }^{\circ} \mathrm{C}$ and diethylazodicarboxylate ( $40 \%$ in toluene), ( $34.2 \mathrm{~mL}, 75.1 \mathrm{mmol}$ ) was carefully added in three batches over 10 minutes. The reaction was stirred while warming from $0{ }^{\circ} \mathrm{C}$ to room temperature. After 20 hours, the solvent was removed under reduced pressure. Diethyl ether was added slowly until a white precipitate formed. The solid was removed by gravity filtration through cotton and rinsed with diethyl ether The filtrate was concentrated under reduced pressure and the resulting crude mixture was purified by flash chromatography (40\% diethylether:hexanes) to give compound 3 ( $7.66 \mathrm{~g}, 70 \%$, $\alpha$-only) as a pale yellow oil. Spectroscopic data were in good agreement with published values. $^{3}$

${ }^{1} \mathrm{H}$ NMR $(500 \mathrm{MHz}$, Chloroform-d) $\delta 7.06-6.99(\mathrm{~m}, 2 \mathrm{H}), 6.87-6.80(\mathrm{~m}, 2 \mathrm{H}), 6.06(\mathrm{~d}, J=10.0,1 \mathrm{H}), 5.91$ (ddd, $J=10.1,2.8,2.0 \mathrm{~Hz}, 1 \mathrm{H}), 5.50(\mathrm{dt}, J=2.7,1.3 \mathrm{~Hz}, 1 \mathrm{H}), 3.96-3.82(\mathrm{~m}, 2 \mathrm{H}), 3.78(\mathrm{~s}, 3 \mathrm{H}), 1.48(\mathrm{~d}, J=$ $8.0 \mathrm{~Hz}, 1 \mathrm{H}), 1.33(\mathrm{~d}, J=5.9 \mathrm{~Hz}, 3 \mathrm{H})$.

${ }^{13} \mathrm{C}$ NMR $(126 \mathrm{MHz}$, Chloroform-d) $\delta 155.12,151.63,134.25,126.34,118.54,114.74,94.19,69.70,68.96$, $55.83,18.10$.

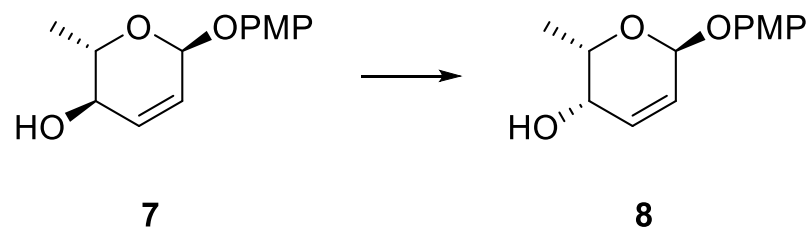

p-methoxyphenyl 2,3-dideoxy- $\alpha$-L-threo-hex-2-enepyranoside Compound 7 (7.66 g, 32.4 $\mathrm{mmol})$, triphenylphosphine (13.61 $\mathrm{g}, 51.87 \mathrm{mmol})$, and $p$-nitrobenzoic acid $(6.50 \mathrm{~g}, 38.9 \mathrm{mmol})$ were dissolved in $98 \mathrm{~mL}$ dry THF and cooled to $0{ }^{\circ} \mathrm{C}$. Diisopropylazodicarboxylate $(10.21 \mathrm{~mL}, 51.87 \mathrm{mmol})$ was added slowly over 15 minutes. The reaction was let to stir while warming from $0{ }^{\circ} \mathrm{C}$ to room temp. After 20 hours, the solvent was removed under reduced pressure. The resulting crude solid was suspended in diethyl ether and filtered through a large plug of silica gel, eluting with $50 \%$ diethyl ether:hexanes. The filtrate was concentrated under reduced pressure and the resulting crude solid was dissolved in $26 \mathrm{~mL}$ dichloromethane. The solution was treated with solid sodium methoxide ( $420 \mathrm{mg}, 7.7805 \mathrm{mmol})$, followed by a gradual addition of $78 \mathrm{~mL}$ methanol. The reaction was stirred at room temperature for 22 hours, then the solvent was removed under reduced pressure. The resulting crude was purified by flash chromatography (50\% diethylether:hexanes) affording compound 8 as a white solid $(5.16 \mathrm{~g}, 67 \%)$. Spectroscopic data was in good agreement with published values. ${ }^{3}$

${ }^{1} \mathrm{H}$ NMR $(500 \mathrm{MHz}$, Chloroform-d) $\delta 7.07-7.00(\mathrm{~m}, 2 \mathrm{H}), 6.87-6.80(\mathrm{~m}, 2 \mathrm{H}), 6.30(\mathrm{dd}, J=9.9,5.6 \mathrm{~Hz}, 1 \mathrm{H})$, $6.03(\mathrm{dd}, J=9.9,3.2 \mathrm{~Hz}, 1 \mathrm{H}), 5.53(\mathrm{dd}, J=3.3,1.0 \mathrm{~Hz}, 1 \mathrm{H}), 4.30(\mathrm{qd}, J=6.6,2.2 \mathrm{~Hz}, 1 \mathrm{H}), 3.78(\mathrm{~s}, 3 \mathrm{H}), 3.68$ (ddd, $J=10.2,5.6,2.2 \mathrm{~Hz}, 1 \mathrm{H}), 1.61-1.52(\mathrm{~m}, 1 \mathrm{H}), 1.30(\mathrm{~d}, J=6.6 \mathrm{~Hz}, 3 \mathrm{H})$.

${ }^{13} \mathrm{C}$ NMR (126 MHz, Chloroform-d) $\delta$ 155.15, 151.58, 131.10, 127.72, 118.58, 114.75, 94.45, 67.38, 63.96, $55.82,16.19$. 
<smiles>C[C@@H]1O[C@@H](O[18F])C=C[C@H]1O</smiles>

8

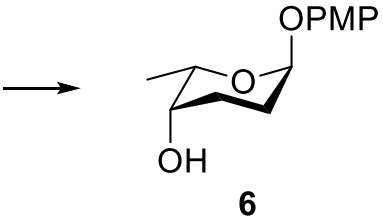

6

p-methoxyphenyl 2,3-dideoxy- $\alpha$-L-fucopyranoside In a two-neck round bottom flask, rhodium on alumina ( $5 \% \mathrm{wt}$ ) ( $985 \mathrm{mg}, 0.48 \mathrm{mmol}$ ) was suspended in $115 \mathrm{~mL}$ ethyl acetate and $26 \mathrm{~mL}$ toluene. Compound 8 (11.3 g, $47.82 \mathrm{mmol}$ ) was dissolved in $115 \mathrm{~mL}$ ethyl acetate and added to the rhodium suspension. Hydrogen gas (balloon, $1 \mathrm{~atm}$ ) was bubbled into the reaction at room temperature three times and the reaction was left to stir under hydrogen gas. Hydrogen was replenished as needed until reaction reached completion as determined by TLC (approx. 3 hours). The reaction was filtered through silica gel with ethyl acetate to remove rhodium ( $1 \mathrm{~L}$ ethyl acetate). The solvent was then removed under reduced pressure. The resulting crude mixture was purified by flash chromatography (10\% to $20 \%$ ethyl acetate:dichloromethane) to afford compound 5 as a white solid (8.36 g, 73\%). Spectroscopic data is in good agreement with published spectroscopic data. ${ }^{4}$

${ }^{1} \mathrm{H}$ NMR $(500 \mathrm{MHz}$, Chloroform-d) $\delta 7.04-6.97(\mathrm{~m}, 2 \mathrm{H}), 6.86-6.79(\mathrm{~m}, 2 \mathrm{H}), 5.43(\mathrm{~d}, J=3.4 \mathrm{~Hz}, 1 \mathrm{H}), 4.10$ (qd, $J=6.6,1.3 \mathrm{~Hz}, 1 \mathrm{H}), 3.77(\mathrm{~s}, 3 \mathrm{H}), 3.68-3.61(\mathrm{~m}, 1 \mathrm{H}), 2.26-2.15(\mathrm{~m}, 1 \mathrm{H}), 2.15-2.04(\mathrm{~m}, 1 \mathrm{H}), 1.91-$ $1.83(\mathrm{~m}, 1 \mathrm{H}), 1.87-1.81(\mathrm{~m}, 1 \mathrm{H}), 1.80-1.72(\mathrm{~m}, 1 \mathrm{H}), 1.15(\mathrm{~d}, J=6.6 \mathrm{~Hz}, 3 \mathrm{H})$.

${ }^{13} \mathrm{C}$ NMR $(126 \mathrm{MHz}$, Chloroform-d) $\delta 154.72,151.28,117.82,114.70,96.63,67.41,67.07,55.80,25.86$, $23.75,17.22$.

S2.3 Synthesis of L-rhodinose Donor 19

\begin{tabular}{|c|c|c|c|c|}
\hline OPMP & & & & \\
\hline & $\mathrm{NaH}(60 \%)$, TBAI, $\mathrm{BnBr}$ & & CAN & \\
\hline 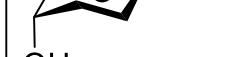 & DMF, $0{ }^{\circ} \mathrm{C}$ to $\mathrm{rt}$ & & $\mathrm{MeCN} / \mathrm{H}_{2} \mathrm{O}(10: 1)$ & ONan \\
\hline 6 & & trap & & 19 \\
\hline
\end{tabular}

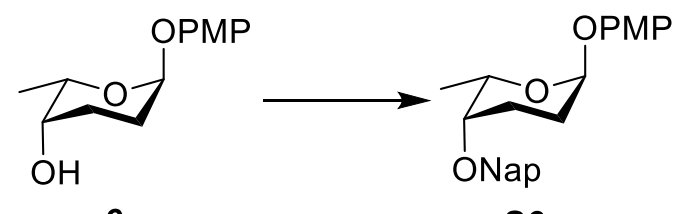

6

S6

p-methoxyphenyl 2,3-dideoxy-4-0-(2-napthylmethyl)- $\alpha$-L-fucopyranoside In a flame-dried flask, sodium hydride ( $60 \%$ suspension in mineral oil) $(147 \mathrm{mg}, 3.67 \mathrm{mmol}$ ) and TBAl (78 mg, $0.21 \mathrm{mmol})$ were suspended in $5 \mathrm{~mL} \mathrm{DMF}$ and cooled to $0{ }^{\circ} \mathrm{C}$. Compound 6 ( $500 \mathrm{mg}, 2.09 \mathrm{mmol}$ ) was dissolved in 2 $\mathrm{mL}$ DMF and transferred to the sodium hydride and allowed to stir at $0{ }^{\circ} \mathrm{C}$ for 15 minutes. $\mathrm{NapBr}(696$ $\mathrm{mg}, 3.15 \mathrm{mmol}$ ) was dissolved in $2 \mathrm{~mL} \mathrm{DMF}$, added into the reaction and stirred $0{ }^{\circ} \mathrm{C}$ to $\mathrm{rt}$. After 90 minutes, the reaction was quenched by adding $2 \mathrm{~mL}$ saturated ammonium chloride. The reaction was poured over $75 \mathrm{~mL}$ water and extracted with diethyl ether $(3 \times 75 \mathrm{~mL})$. The combined organic layers 
were washed with $1 \mathrm{M}$ lithium chloride $(50 \mathrm{~mL})$, dried over sodium sulfate, filtered through cotton and concentrated under reduced pressure. The resulting crude mixture was purified by flash chromatography (5\% to 10\% Ethyl acetate:hexanes) giving the product $\mathbf{S 6}$ as a white solid (683 $\mathrm{mg}, 86 \%$ yield).

${ }^{1} \mathrm{H}$ NMR $(500 \mathrm{MHz}$, Chloroform-d) $\delta 7.86-7.78(\mathrm{~m}, 4 \mathrm{H}), 7.55-7.43(\mathrm{~m}, 3 \mathrm{H}), 7.05-6.96(\mathrm{~m}, 2 \mathrm{H}), 6.85-$ $6.78(\mathrm{~m}, 2 \mathrm{H}), 5.49(\mathrm{~d}, J=3.3 \mathrm{~Hz}, 1 \mathrm{H}), 4.87(\mathrm{~d}, J=12.3 \mathrm{~Hz}, 1 \mathrm{H}), 4.64(\mathrm{~d}, J=12.3 \mathrm{~Hz}, 1 \mathrm{H}), 4.05(\mathrm{qd}, J=6.6$, $1.6 \mathrm{~Hz}, 1 \mathrm{H}), 3.76(\mathrm{~s}, 3 \mathrm{H}), 3.38(\mathrm{~s}, 1 \mathrm{H}), 2.26-2.14(\mathrm{~m}, 1 \mathrm{H}), 2.10-2.00(\mathrm{~m}, 2 \mathrm{H}), 1.77-1.69(\mathrm{~m}, 1 \mathrm{H}), 1.18$ $(\mathrm{d}, J=6.6 \mathrm{~Hz}, 3 \mathrm{H})$.

${ }^{13} \mathrm{C}$ NMR $\left(126 \mathrm{MHz}, \mathrm{CDCl}_{3}\right) \delta 154.57,151.49,136.27,133.39,133.14,128.24,127.99,127.85,126.61$, $126.23,126.15,125.97,117.74,114.68,96.63,73.47,71.26,67.42,55.81,24.34,21.49,17.49$.

HRMS (TOF MS ES+): $\mathrm{m} / \mathrm{z}$ calculated for $\mathrm{C}_{24} \mathrm{H}_{26} \mathrm{O}_{4} \mathrm{Na}(\mathrm{M}+\mathrm{Na}): 401.1729$, found: $401.1724(\mathrm{M}+\mathrm{Na})$

$[\alpha]_{\lambda}^{23}\left(c=1.04, \mathrm{CH}_{2} \mathrm{Cl}_{2}\right):-28.43 \pm 0.403$

m.p. $=102-103^{\circ} \mathrm{C}$

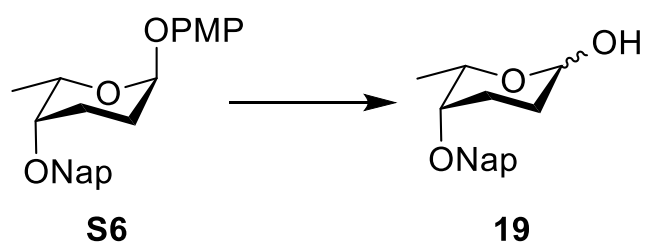

2,3-dideoxy-4-0-(2-napthylmethyl)- $\alpha / \beta$-L-fucopyranoside Compound $\mathbf{S 6}$ (600 mg, $1.58 \mathrm{mmol}$ ) was dissolved in $84.1 \mathrm{~mL}$ acetonitrile and $8.4 \mathrm{~mL} \mathrm{H}_{2} \mathrm{O}$. Ceric ammonium nitrate (CAN) $(1.74 \mathrm{~g}, 3.17 \mathrm{mmol})$ was added as a solid and the reaction was stirred at room temperature for 5 minutes. The reaction was poured over saturated sodium bicarbonate $(100 \mathrm{~mL})$ and extracted with dichlormethane $(3 \times 75 \mathrm{~mL})$. The combined organic layers were washed with water $(50 \mathrm{~mL}), 10 \%$ sodium sulfite $(50 \mathrm{~mL})$ and brine $(50$ $\mathrm{mL}$ ). The organic layers were dried over sodium sulfate, filtered through cotton, and concentrated under reduced pressure. The crude mixture was separated by flash chromatography ( $30 \%$ to $50 \%$ ethyl acetate:hexanes) to give compound 19 as a white solid (405 $\mathrm{mg}, 94 \%, \alpha: \beta=1.3: 1$ ).

${ }^{1} \mathrm{H}$ NMR $(500 \mathrm{MHz}$, Chloroform-d) $\delta 7.88-7.74(\mathrm{~m}, 7 \mathrm{H}), 7.55-7.42(\mathrm{~m}, 5 \mathrm{H}), 5.35(\mathrm{~s}, 1 \mathrm{H}), 4.88-4.81(\mathrm{~m}$, $2 \mathrm{H}), 4.80-4.72(\mathrm{~m}, 1 \mathrm{H}), 4.65-4.57(\mathrm{~m}, 2 \mathrm{H}), 4.18(\mathrm{qd}, J=6.6,1.7 \mathrm{~Hz}, 1 \mathrm{H}), 3.65(\mathrm{qd}, J=6.4,1.5 \mathrm{~Hz}, 1 \mathrm{H})$, $3.34(\mathrm{~s}, 1 \mathrm{H}), 3.26-3.21(\mathrm{~m}, 1 \mathrm{H}), 3.05-3.02(\mathrm{~m}, 1 \mathrm{H}), 2.21-2.15(\mathrm{~m}, 1 \mathrm{H}), 2.08-2.02(\mathrm{~m}, 1 \mathrm{H}), 2.00-1.85$ $(\mathrm{m}, 2 \mathrm{H}), 1.80-1.70(\mathrm{~m}, 2 \mathrm{H}), 1.61-1.47(\mathrm{~m}, 3 \mathrm{H}), 1.29(\mathrm{~d}, J=6.4 \mathrm{~Hz}, 2 \mathrm{H}), 1.21(\mathrm{~d}, J=6.6 \mathrm{~Hz}, 3 \mathrm{H})$.

${ }^{13} \mathrm{C}$ NMR $\left(126 \mathrm{MHz}, \mathrm{CDCl}_{3}\right) \delta 136.20,136.09,133.35,133.33,133.13,129.18,128.37,128.24,127.98$, $127.85,126.71,126.25,126.23,126.20,126.01,125.98,96.46,91.91,74.33,73.46,72.38,71.25,71.13$, $66.73,28.02,25.58,24.21,20.86,17.61,17.51$.

LRMS (TOF MS El+): $\mathrm{m} / \mathrm{z}$ calculated for $\mathrm{C}_{17} \mathrm{H}_{20} \mathrm{O}_{3}(\mathrm{M}): 272.1$, Found: 272.1, $254.1\left(\mathrm{M}-\mathrm{H}_{2} \mathrm{O}\right)$

HRMS (TOF MS ES+): $\mathrm{m} / \mathrm{z}$ calculated for $\mathrm{C}_{17} \mathrm{H}_{20} \mathrm{O}_{3} \mathrm{Na}(\mathrm{M}+\mathrm{Na}$ ): 295.1310 Found:295.1310

$[\alpha]_{\lambda}^{23}\left(\mathrm{c}=1.07, \mathrm{CH}_{2} \mathrm{Cl}_{2}\right): 1.37 \pm 0.12$ 
S2.4 Synthesis of L-rhodinose Donor 3

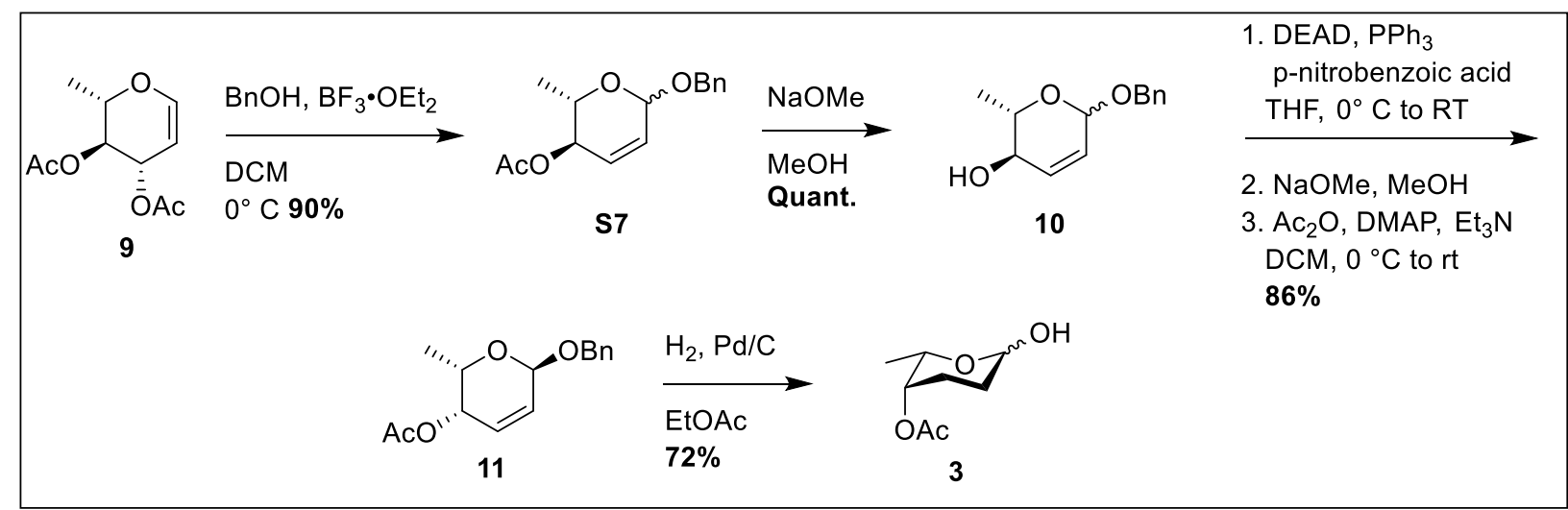<smiles></smiles>

9

S7

Benzyl 2,3,6-trideoxy-4-0-acetyl- $\alpha / \beta$-L-erythro-hex-2-enepyranoside Di-O-acetyl-L-rhamnal 9 (15 g, $70.02 \mathrm{mmol}$ ) and benzyl alcohol (10.88 $\mathrm{mL}, 105.03 \mathrm{mmol}$ ) were dissolved in $69 \mathrm{~mL}$ dry dichloromethane and cooled to $0{ }^{\circ} \mathrm{C}$. Boron trifluoride diethyletherate $(3.5 \mathrm{~mL}, 28 \mathrm{mmol})$ was added dropwise at $0{ }^{\circ} \mathrm{C}$ and the reaction was stirred at $0{ }^{\circ} \mathrm{C}$. After 1 hour, the reaction was quenched with 60 $\mathrm{mL}$ of saturated sodium bicarbonate solution and left to sit until the color changed from blue to brown. The reaction was diluted over $150 \mathrm{~mL}$ saturate sodium bicarbonate and extracted with dichloromethane $(4 \times 125 \mathrm{~mL})$. The combined dichloromethane layers were washed with saturated sodium bicarbonate (1 $x 100 \mathrm{~mL}$ ) and brine $(1 \times 100 \mathrm{~mL})$. The organic layer was dried over sodium sulfate, filtered through cotton, and concentrated under reduced pressure. The resulting crude was purified by flash chromatography (5\% to $10 \%$ ethyl acetate:hexanes) to give compound $\mathbf{S 7}(12.59 \mathrm{~g}, 68 \% \alpha: \beta=7.1: 1)$ as a clear oil in good agreement with reported spectroscopic data. ${ }^{5}$

${ }^{1} \mathrm{H}$ NMR $(500 \mathrm{MHz}$, Chloroform-d) $\delta 7.41-7.27(\mathrm{~m}, 5 \mathrm{H}), 5.88-5.80(\mathrm{~m}, 2 \mathrm{H}), 5.10-5.03(\mathrm{~m}, 2 \mathrm{H}), 4.78(\mathrm{~d}$, $J=11.9 \mathrm{~Hz}, 1 \mathrm{H}), 4.60(\mathrm{~d}, J=11.9 \mathrm{~Hz}, 1 \mathrm{H}), 4.01(\mathrm{dq}, J=9.8,6.5 \mathrm{~Hz}, 1 \mathrm{H}), 2.08(\mathrm{~s}, 3 \mathrm{H}), 1.19(\mathrm{~d}, J=6.2 \mathrm{~Hz}$, $3 \mathrm{H})$.

${ }^{13} \mathrm{C} \mathrm{NMR}\left(126 \mathrm{MHz}, \mathrm{CDCl}_{3}\right) \delta 170.65,138.16,129.95,128.57,128.12,127.94,127.86,93.85,71.11,70.31$, $65.12,21.20,18.03,0.13$. 


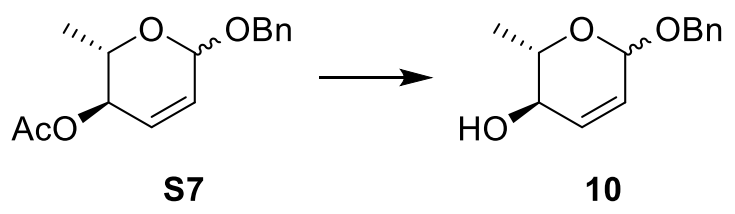

Benzyl 2,3,6-trideoxy- $\alpha / \beta$-L-erythro-hex-2-enepyranoside Compound S7 (12.59 g, 47.99 mmol) was dissolved in $78 \mathrm{~mL}$ methanol. Sodium methoxide $(259 \mathrm{mg}, 4.79 \mathrm{mmol}$ ) was added as a solid and the reaction was allowed to stir for 1 hour. The solvent was removed under reduced pressure and the resulting crude purified by flash chromatography ( $20 \%$ to $40 \%$ ethyl acetate:hexanes) affording compound 10 as a white solid ( $10.57 \mathrm{~g}$, quant., $\alpha: \beta=7.1: 1)$ in good agreement with reported spectroscopic data. ${ }^{5}$

${ }^{1} \mathrm{H}$ NMR $(500 \mathrm{MHz}$, Chloroform-d) $\delta 7.39-7.27(\mathrm{~m}, 5 \mathrm{H}), 5.94(\mathrm{~d}, J=10.2 \mathrm{~Hz}, 1 \mathrm{H}), 5.81-5.74(\mathrm{~m}, 1 \mathrm{H})$, $5.04(\mathrm{~s}, 0 \mathrm{H}), 4.78(\mathrm{~d}, J=11.8 \mathrm{~Hz}, 1 \mathrm{H}), 4.59(\mathrm{~d}, J=11.9 \mathrm{~Hz}, 1 \mathrm{H}), 3.86(\mathrm{tq}, J=8.5,1.8 \mathrm{~Hz}, 1 \mathrm{H}), 3.76(\mathrm{dq}, J=$ 8.9, $6.2 \mathrm{~Hz}, 1 \mathrm{H}), 1.36(\mathrm{~d}, J=8.4 \mathrm{~Hz}, 1 \mathrm{H}), 1.30(\mathrm{~d}, J=6.2 \mathrm{~Hz}, 3 \mathrm{H})$.

${ }^{13} \mathrm{C} \mathrm{NMR}\left(126 \mathrm{MHz}, \mathrm{CDCl}_{3}\right) \delta 138.21,133.57,128.57,128.16,127.85,126.96,93.78,70.22,69.95,68.33$, 18.05 .

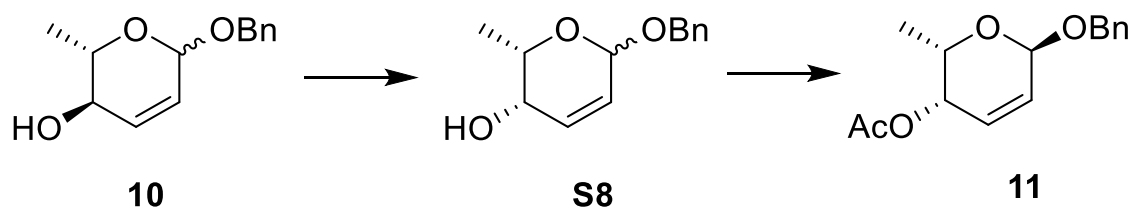

Benzyl 2,3,6-trideoxy-4-0-acetyl- $\alpha / \beta$-L-threo-hex-2-enepyranoside A flame-dried round bottom flask was charged with triphenylphosphine $(25.17 \mathrm{~g}, 95.97 \mathrm{mmol})$ and $p$-nitrobenzoic acid $(9.62$ $\mathrm{g}, 57.58 \mathrm{mmol})$. Compound 10 (10.57 g, $47.97 \mathrm{mmol})$ was dissolved in tetrahydrofuran $(142 \mathrm{~mL})$ and added to the reaction flask via cannula. The reaction was cooled to $0{ }^{\circ} \mathrm{C}$ and diethylazodicarboxylate (40\% wt. in toluene, $43.7 \mathrm{~mL}, 96.0 \mathrm{mmol}$ ) was added at $0{ }^{\circ} \mathrm{C}$ in three additions over ten minutes and the reaction was stirred from $0{ }^{\circ} \mathrm{C}$ to rt. After 18 hours, the reaction was quenched by pouring over saturated sodium bicarbonate $(200 \mathrm{~mL})$. The aqueous layer was extracted with diethyl ether $(3 \times 100$ $\mathrm{mL}$ ). The combined organic layers were concentrated under reduced pressure. Diethyl ether was added slowly to the concentrate until a solid precipitated out. The suspension was filtered through a cotton filter with diethyl ether and the filtrate was concentrated under reduced pressure. The crude concentrate was dissolved in $140 \mathrm{~mL}$ methanol and $40 \mathrm{~mL}$ dichloromethane. Sodium methoxide (540 $\mathrm{mg}, 9.59 \mathrm{mmol}$ ) was added as a solid and the reaction was let to stir at room temperature. After 2 hours, the solvent was removed under reduced pressure and the resulting crude was roughly purified by flash chromatography (20\% to $60 \%$ ethyl acetate:hexanes) to remove the major byproducts and afford crude compound $\mathbf{S} 8$ was a yellow-white solid. The partially purified mixture was dissolved in dichlormethane $(271 \mathrm{~mL})$ with DMAP $(2.17 \mathrm{~g}, 17.7 \mathrm{mmol})$ and cooled to $0{ }^{\circ} \mathrm{C}$. Triethylamine $(13.4 \mathrm{~mL}, 95.9 \mathrm{mmol})$ was added followed by acetic anhydride $(9.0 \mathrm{~mL}, 95 \mathrm{mmol})$. The reaction was stirred $0{ }^{\circ} \mathrm{C}$ to room temp. After 2 hours, the solvent was removed under reduced pressure and the crude mixture was purified by flash chromatography (10\% ethyl acetate:hexanes) affording compound $\mathbf{1 1}$ as a white solid (10.85 g, $86 \%)$ in good agreement with published spectroscopic data. ${ }^{6}$ 
${ }^{1} \mathrm{H}$ NMR $(500 \mathrm{MHz}$, Chloroform-d) $\delta 7.40-7.27(\mathrm{~m}, 5 \mathrm{H}), 6.09$ (dd, $J=9.9,5.4 \mathrm{~Hz}, 1 \mathrm{H}), 6.03$ (dd, $J=10.0$, $3.0 \mathrm{~Hz}, 1 \mathrm{H}), 5.13(\mathrm{~d}, J=3.0 \mathrm{~Hz}, 1 \mathrm{H}), 4.93(\mathrm{dd}, J=5.4,2.4 \mathrm{~Hz}, 1 \mathrm{H}), 4.77(\mathrm{~d}, J=11.8 \mathrm{~Hz}, 1 \mathrm{H}), 4.62(\mathrm{~d}, J=11.9$ $\mathrm{Hz}, 1 \mathrm{H}), 4.27(\mathrm{qd}, J=6.6,2.5 \mathrm{~Hz}, 1 \mathrm{H}), 2.10(\mathrm{~s}, 3 \mathrm{H}), 1.19(\mathrm{~d}, J=6.6 \mathrm{~Hz}, 3 \mathrm{H})$.

${ }^{13} \mathrm{C}$ NMR (126 MHz, Chloroform-d) $\delta$ 170.80, 138.05, 130.56, 128.60, 128.22, 127.93, 126.25, 93.66, $70.16,65.25,64.95,20.99,16.09$.<smiles>CC(=O)O[C@H]1C=C[C@@H](OCc2ccccc2)O[C@@H]1C</smiles>

11

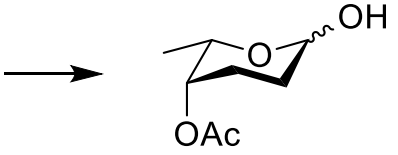

3

2,3-dideoxy-4-0-acetyl- $\alpha / \beta$-L-fucopyranoside In a two-neck round bottom flask, palladium on carbon (10\% wt, $1.026 \mathrm{~g}, 0.87 \mathrm{mmol}$ ) was suspended in $55 \mathrm{~mL}$ ethyl acetate. Compound 11 (5.68 g, $21.65 \mathrm{mmol}$ ) was dissolved in $55 \mathrm{~mL}$ ethyl acetate and added to reaction flask. Hydrogen gas (balloon, 1 atm) was bubbled into the reaction three times and the reaction was stirred at room temperature under hydrogen. The hydrogen balloon was refreshed as needed until the starting material was seen to be consumed on TLC. The palladium on carbon was removed by filtering through a bed of silica with ethyl acetate $(1 \mathrm{~L})$. The filtrate was concentrated under reduced pressure and purified by flash chromatorgraphy (50\% ethyl acetate:hexanes) to afford compound 3 as a clear oil $(2.73 \mathrm{~g}, 72 \%, \alpha: \beta=$ 1.2:1) in good agreement with published spectroscopic data ${ }^{7}$

${ }^{1} \mathrm{H}$ NMR $(500 \mathrm{MHz}$, Chloroform-d) $\delta 5.36(\mathrm{~s}, 1 \mathrm{H}), 4.86-4.79(\mathrm{~m}, 2 \mathrm{H}), 4.76(\mathrm{~s}, 1 \mathrm{H}), 4.28$ (qd, J = 6.6, 1.6 $\mathrm{Hz}, 1 \mathrm{H}), 3.80-3.72(\mathrm{~m}, 1 \mathrm{H}), 3.19(\mathrm{dd}, J=6.6,2.2 \mathrm{~Hz}, 1 \mathrm{H}), 2.70(\mathrm{~s}, 1 \mathrm{H}), 2.19-2.09(\mathrm{~m}, 7 \mathrm{H}), 2.08-2.01$ $(\mathrm{m}, 1 \mathrm{H}), 1.98-1.88(\mathrm{~m}, 1 \mathrm{H}), 1.88-1.72(\mathrm{~m}, 3 \mathrm{H}), 1.70-1.57(\mathrm{~m}, 2 \mathrm{H}), 1.21(\mathrm{~d}, J=6.5 \mathrm{~Hz}, 3 \mathrm{H}), 1.12(\mathrm{~d}, J=$ $6.6 \mathrm{~Hz}, 3 \mathrm{H})$.

${ }^{13} \mathrm{C}$ NMR (126 MHz, Chloroform-d) $\delta 170.94$ (2C), 96.23, 91.78, 72.86, 69.61, 68.24, 65.11, 27.67, 27.31, 24.22, 22.40, 21.24, 21.21, 17.32, 17.29. 
S2.5 Synthesis of D-olivose Donor 5

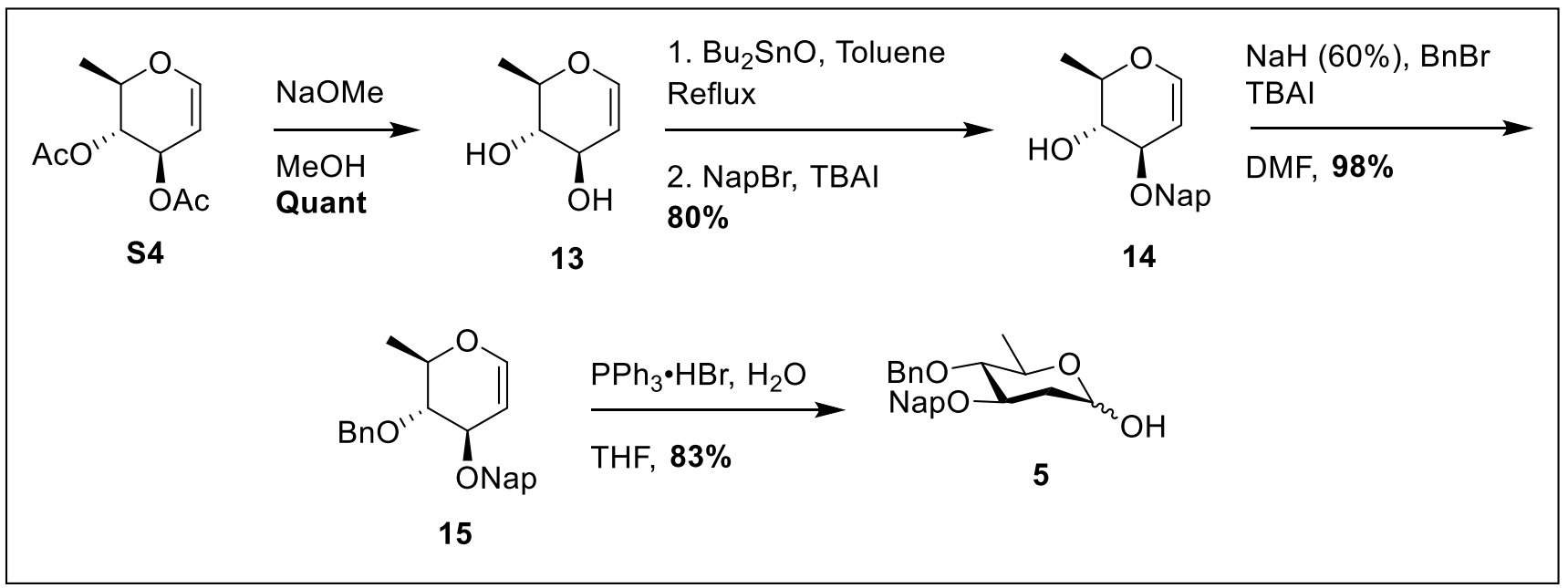<smiles>CC(=O)O[C@H]1C=CO[C@H](C)[C@H]1OC(C)C</smiles>

S4

13

D-rhamnal Di-O-acetyl-D-rhamnal S4 (16.51g, 76.24) was dissolved in $124 \mathrm{~mL} \mathrm{MeOH}$. Sodium methoxide $(2.06 \mathrm{~g}, 38.12 \mathrm{mmol}$ ) was added as a solid and the solution was allowed to stir at room temperature. After one hour, the solvent was removed under reduced pressure. The resulting crude mixture was purified by flash chromatography $\left(10 \% \mathrm{MeOH}: \mathrm{CH}_{2} \mathrm{Cl}_{2}\right)$ to afford compound 13 as a white solid (9.92 g, quantitative yield) with NMR spectra in good agreement with previously reported data. ${ }^{8}$

${ }^{1} \mathrm{H}$ NMR $(500 \mathrm{MHz}$, Chloroform-d) $\delta 6.34$ (dd, $J=6.1,1.8 \mathrm{~Hz}, 1 \mathrm{H}), 4.74$ (dd, $\left.J=6.0,2.1 \mathrm{~Hz}, 1 \mathrm{H}\right), 4.27-$ $4.20(\mathrm{~m}, 1 \mathrm{H}), 3.90(\mathrm{dq}, J=9.8,6.3 \mathrm{~Hz}, 1 \mathrm{H}), 3.45(\mathrm{ddd}, J=9.7,7.3,3.9 \mathrm{~Hz}, 1 \mathrm{H}), 2.51-2.42(\mathrm{~m}, 1 \mathrm{H}), 1.98-$ $1.89(\mathrm{~m}, 1 \mathrm{H}), 1.42(\mathrm{~d}, J=6.3 \mathrm{~Hz}, 3 \mathrm{H})$.

${ }^{13} \mathrm{C}$ NMR $\left(126 \mathrm{MHz}, \mathrm{CDCl}_{3}\right) \delta 144.84,102.65,75.62,74.40,70.37,17.10$.<smiles>C[C@H]1OC=C[C@@H](O)[C@@H]1O</smiles>

13<smiles>C[C@@H]1OC=C[C@@H](O)[C@H]1O</smiles>

14

3-0-(2-napthylmethyl)-D-rhamnal D-rhamnal 13 (9.93 g, $76.3 \mathrm{mmol}$ ) was suspended with dibutyltin oxide (20.89 g, $83.93 \mathrm{mmol})$ in $223 \mathrm{~mL}$ toluene in a flask fitted with Dean-Stark apparatus and 
heated in a $130^{\circ} \mathrm{C}$ oil bath for 4 hours. After cooling to room temperature, the reaction was treated with $\operatorname{NapBr}(25.30 \mathrm{~g}, 114.4 \mathrm{mmol})$ and TBAI $(5.64 \mathrm{~g}, 15.3 \mathrm{mmol})$, and the reaction was returned to the to the $130{ }^{\circ} \mathrm{C}$ oil bath. After stirring for 18 hours, the reaction was cooled to room temperature and the solvent was removed under reduced pressure. The crude mixture was purified by flash chromatography ( $10 \%$ to $30 \%$ ethyl acetate:hexanes) to afford compound 14 as a yellow solid $(16.42 \mathrm{~g}, 80 \%)$ with spectroscopic values in good agreement with published compound. ${ }^{9}$

${ }^{1} \mathrm{H}$ NMR $(500 \mathrm{MHz}$, Chloroform-d) $\delta 7.87-7.75(\mathrm{~m}, 4 \mathrm{H}), 7.52-7.44(\mathrm{~m}, 3 \mathrm{H}), 6.36(\mathrm{dd}, J=6.1,1.5 \mathrm{~Hz}, 1 \mathrm{H})$, $4.90-4.83(\mathrm{~m}, 2 \mathrm{H}), 4.72(\mathrm{~d}, J=12.0 \mathrm{~Hz}, 1 \mathrm{H}), 4.10(\mathrm{dt}, J=7.0,1.9 \mathrm{~Hz}, 1 \mathrm{H}), 3.90(\mathrm{dq}, J=9.4,6.4 \mathrm{~Hz}, 1 \mathrm{H})$, 3.65 (ddd, $J=9.3,7.0,3.7 \mathrm{~Hz}, 1 \mathrm{H}), 2.18(\mathrm{~d}, J=3.7 \mathrm{~Hz}, 1 \mathrm{H}), 1.39(\mathrm{~d}, J=6.4 \mathrm{~Hz}, 3 \mathrm{H}$ ).

${ }^{13} \mathrm{C}$ NMR (126 MHz, Chloroform-d) $\delta 145.19,135.95,133.47,133.20,128.53,128.04,127.88,126.71$, $126.36,126.13,125.86,99.90,77.01,74.63,72.99,70.82,17.28$.<smiles>C[C@@H]1OC=C[C@@H](O)[C@H]1O</smiles>

14<smiles></smiles>

15

4-0-benzyl-3-0-(2-napthylmethyl)-D-rhamnal In a flame dried flask, sodium hydride (60\% in mineral oil) ( $3.70 \mathrm{~g}, 92.7 \mathrm{mmol}$ ) and TBAI $(3.42 \mathrm{~g}, 9.26 \mathrm{mmol})$ were suspended in 162 anhydrous DMF and cooled to $0{ }^{\circ} \mathrm{C}$. Compound 14 was dissolved in $61 \mathrm{~mL}$ DMF and added into the sodium hydride solution via cannula and allowed to stir at $0{ }^{\circ} \mathrm{C}$ for 30 minutes. Benzyl bromide $(11.9 \mathrm{~g}, 8.26 \mathrm{~mL}, 69.5$ $\mathrm{mmol}$ ) was added slowly and the reaciton was allowed to stir while gradually warming from $0{ }^{\circ} \mathrm{C}$ to room temperature for 13 hours. The reaction was quenched by the addition of $20 \mathrm{~mL}$ saturated ammonium chloride. The reaction was diluted over $200 \mathrm{~mL}$ water and extracted with diethyl ether $(3 \times 150 \mathrm{~mL})$. The combined ether layers were washed with water $(3 \times 150 \mathrm{~mL})$, brine $(1 \times 150 \mathrm{~mL})$, dried over sodium sulfate, filtered through cotton, and the solvent removed under reduced pressure. The crude mixture was purified by flash chromatography ( $5 \%$ to $10 \%$ ethyl acetate:hexanes) to afford compound $\mathbf{1 5}$ as a white solid (16.4 g, 98\%) in good agreement with published spectroscopic data. ${ }^{10}$

${ }^{1} \mathrm{H}$ NMR $(500 \mathrm{MHz}$, Chloroform-d) $\delta 7.85-7.76(\mathrm{~m}, 4 \mathrm{H}), 7.50-7.43(\mathrm{~m}, 3 \mathrm{H}), 7.35-7.26(\mathrm{~m}, 5 \mathrm{H}), 6.37$ (dd, $J=6.2,1.4 \mathrm{~Hz}, 1 \mathrm{H}), 4.91(\mathrm{~d}, J=11.1 \mathrm{~Hz}, 1 \mathrm{H}), 4.89(\mathrm{dd}, J=6.0,2.8 \mathrm{~Hz}, 1 \mathrm{H}), 4.83(\mathrm{~d}, J=11.9 \mathrm{~Hz}, 1 \mathrm{H})$, $4.76-4.70(\mathrm{~m}, 2 \mathrm{H}), 4.27$ (ddd, $J=6.5,2.5,1.5 \mathrm{~Hz}, 1 \mathrm{H}$ ), 3.96 (dq, $J=9.1,6.4 \mathrm{~Hz}, 1 \mathrm{H}$ ), 3.52 (dd, $J=9.0,6.5$ $\mathrm{Hz}, 1 \mathrm{H}), 1.39(\mathrm{~d}, J=6.4 \mathrm{~Hz}, 3 \mathrm{H})$.

${ }^{13} \mathrm{C}$ NMR $\left(126 \mathrm{MHz}, \mathrm{CDCl}_{3}\right) \delta 145.01,138.47,136.09,133.47,133.14,128.55,128.31,128.08,128.04$, $127.88,127.84,126.57,126.24,126.01,125.99,100.34,79.79,76.67,74.24,74.18,70.83,17.65,0.14$.<smiles>C[C@@H]1OC=C[C@@H](O[Nb])[C@H]1O[Mg]</smiles>

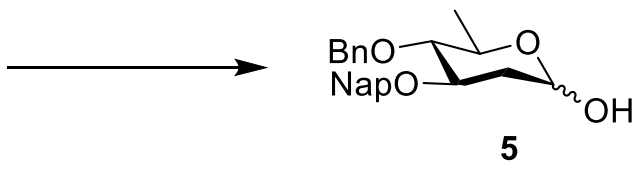

15 


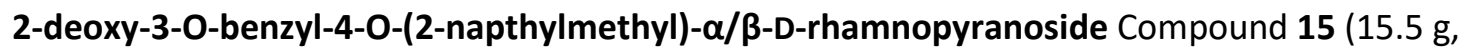
$43.0 \mathrm{mmol}$ ) and triphenylphosphine hydrobromide ( $2.95 \mathrm{~g}, 8.60 \mathrm{mmol})$ were dissolved in $177 \mathrm{~mL}$ THF and the reaction was allowed to stir at room temperature for 25 minutes. ID water $(3.87 \mathrm{~mL}, 215 \mathrm{mmol}$ ) was added and the reaction was allowed to stir for 18 hours. The reaction was diluted over saturated sodium bicarbonate $(200 \mathrm{~mL})$ and extracted with ethyl acetate $(3 \times 175 \mathrm{~mL})$. The combined organic layers were washed with brine, dried over sodium sulfate, filtered through cotton, and the solvent removed under reduced pressure. The crude mixture was purified by flash chromatography (20\% to $40 \%$ ethyl acetate:hexanes). Compound 5 was isolated as a white solid (13.53 g, 83\%, $\alpha: \beta=3.1: 1)$.

Spectroscopic data was in good agreement with previously reported values. ${ }^{10}$

${ }^{1} \mathrm{H}$ NMR (500 MHz, Chloroform- $d$ ) ( $\alpha$-anomer): $\delta 7.85-7.72(\mathrm{~m}, 4 \mathrm{H}), 7.50-7.41(\mathrm{~m}, 3 \mathrm{H}), 7.37-7.26(\mathrm{~m}, 5 \mathrm{H}), 5.34$ $(\mathrm{s}, 1 \mathrm{H}), 4.98(\mathrm{~d}, J=11.0 \mathrm{~Hz}, 1 \mathrm{H}), 4.86-4.73(\mathrm{~m}, 3 \mathrm{H}), 4.71-4.66(\mathrm{~m}, 1 \mathrm{H}), 4.07(\mathrm{ddd}, J=11.4,8.8,5.0 \mathrm{~Hz}, 1 \mathrm{H}), 3.99$ $(\mathrm{dq}, J=9.5,6.3 \mathrm{~Hz}, 1 \mathrm{H}), 3.17(\mathrm{t}, J=9.2 \mathrm{~Hz}, 1 \mathrm{H}), 2.51-2.46(\mathrm{~m}, 1 \mathrm{H}), 2.35(\mathrm{ddd}, J=13.1,5.0,1.5 \mathrm{~Hz}, 1 \mathrm{H}), 1.76-1.67$ $(\mathrm{m}, 1 \mathrm{H}), 1.29(\mathrm{~d}, J=6.2 \mathrm{~Hz}, 3 \mathrm{H})$. ( $\beta$-anomer): $\delta 7.87-7.71(\mathrm{~m}, 4 \mathrm{H}), 7.53-7.41(\mathrm{~m}, 3 \mathrm{H}), 7.37-7.26(\mathrm{~m}, 5 \mathrm{H}), 4.88-$ $4.73(\mathrm{~m}, 3 \mathrm{H}), 4.69(\mathrm{~d}, J=10.9 \mathrm{~Hz}, 1 \mathrm{H}), 3.68(\mathrm{ddd}, J=11.5,8.5,4.9 \mathrm{~Hz}, 1 \mathrm{H}), 3.40(\mathrm{dq}, J=9.3,6.2 \mathrm{~Hz}, 1 \mathrm{H}), 3.10-3.02$ $(\mathrm{m}, 1 \mathrm{H}), 2.43(\mathrm{~m}, 1 \mathrm{H}), 1.59(\mathrm{~m}, 1 \mathrm{H}), 1.33(\mathrm{~d}, J=6.1 \mathrm{~Hz}, 3 \mathrm{H})$.

${ }^{13} \mathrm{C}$ NMR $\left(126 \mathrm{MHz}, \mathrm{CDCl}_{3}\right) \delta 138.76,138.59,136.32,135.92,133.49,133.44,133.17,133.11,128.56$, $128.52,128.38,128.26,128.15,128.09,128.06,128.04,127.89,127.85,127.82,127.78,126.59,126.44$, $126.28,126.18,126.07,125.95,125.95,94.01,92.19,84.55,83.64,79.07,77.03,75.38,75.33,72.06$, $71.76,71.69,67.62,38.62,36.02,18.40,18.38$. 

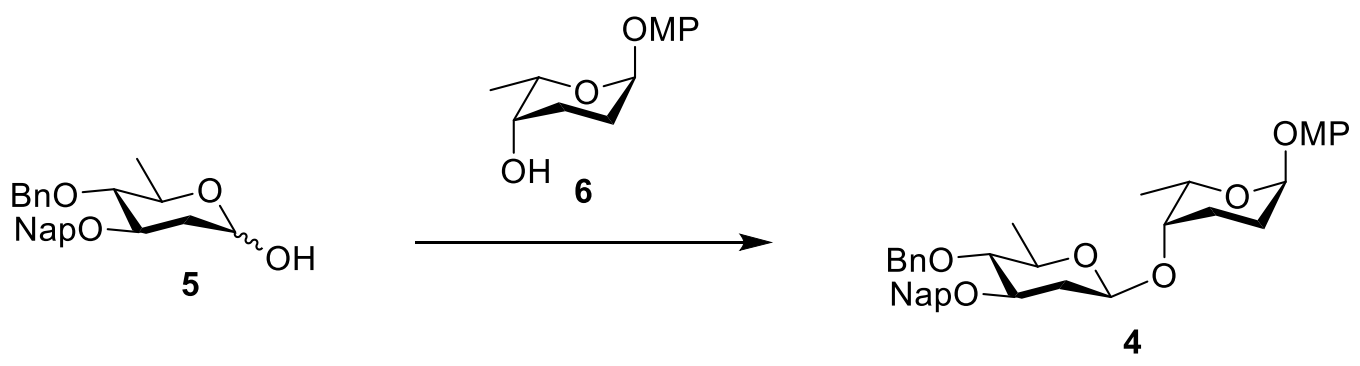

p-methoxyphenyl 2,3-dideoxy-4-0-(2-deoxy-3-0-(2-napthylmethyl)-4-0-benzyl- $\beta$-D-

rhamnopyranosyl)- $\alpha$-L-fucopyranoside Compound $5(1.19 \mathrm{~g}, 3.15 \mathrm{mmol})$ and DTBMP (646 $\mathrm{mg}, 3.15$ $\mathrm{mmol}$ ) were dissolved in $21.1 \mathrm{~mL}$ THF and cooled to $-78^{\circ} \mathrm{C}$. After fifteen minutes, KHMDS (1M in THF) $(3.2 \mathrm{~mL}, 3.2 \mathrm{mmol})$ was added dropwise and the reaction was allowed to stir at $-78^{\circ} \mathrm{C}$ for fifteen minutes. Tosyl chloride ( $600 \mathrm{mg}, 3.15 \mathrm{mmol}$ ) dissolved in $7.3 \mathrm{~mL}$ THF was added slowly to the reaction, which was then allowed to stir for 30 minutes. In a separate flask, compound 6 (500 mg, $2.10 \mathrm{mmol}$ ) was dissolved in $5.8 \mathrm{~mL}$ THF and cooled to $-78^{\circ} \mathrm{C}$. KHMDS (1M in THF) ( $2.1 \mathrm{~mL}, 2.1 \mathrm{mmol}$ ) was added dropwise and the reaction was stirred for 15 minutes. Compound 6 was then transferred via syringe and added dropwise to the primary reaction vessel. The reaction was then stirred for 4 hours while slowly warming to room temperature. The reaction was quenched with $2 \mathrm{~mL}$ of saturated ammonium chloride and poured over $150 \mathrm{~mL}$ water. The water was extracted with diethyl ether $(3 \times 100 \mathrm{~mL})$ and the combined ether layers washed with water $(1 \times 100 \mathrm{~mL})$. The organic layer was dried with sodium sulfate, filtered through cotton, and concentrated under reduced pressure. The resulting crude was purified by flash chromatography ( $10 \%$ ethyl acetate:hexanes) to afford compound $\mathbf{4}$ as an white foam.

${ }^{1} \mathrm{H}$ NMR $(500 \mathrm{MHz}$, Chloroform-d) $\delta 7.85-7.74(\mathrm{~m}, 4 \mathrm{H}), 7.50-7.43(\mathrm{~m}, 3 \mathrm{H}), 7.37-7.26(\mathrm{~m}, 5 \mathrm{H}), 7.04-$ $6.97(\mathrm{~m}, 2 \mathrm{H}), 6.85-6.78(\mathrm{~m}, 2 \mathrm{H}), 5.47(\mathrm{~d}, J=3.0 \mathrm{~Hz}, 1 \mathrm{H}), 4.99(\mathrm{~d}, J=10.9 \mathrm{~Hz}, 1 \mathrm{H}), 4.86(\mathrm{~d}, J=11.9 \mathrm{~Hz}$, $1 \mathrm{H}), 4.75(\mathrm{~d}, J=11.8 \mathrm{~Hz}, 1 \mathrm{H}), 4.69(\mathrm{~d}, J=10.9 \mathrm{~Hz}, 1 \mathrm{H}), 4.45(\mathrm{dd}, J=9.8,1.9 \mathrm{~Hz}, 1 \mathrm{H}), 4.04-3.97(\mathrm{~m}, 1 \mathrm{H})$, $3.77(\mathrm{~s}, 3 \mathrm{H}), 3.67(\mathrm{ddd}, J=11.7,8.6,5.1 \mathrm{~Hz}, 1 \mathrm{H}), 3.53(\mathrm{~s}, 1 \mathrm{H}), 3.32(\mathrm{dq}, J=9.2,6.4 \mathrm{~Hz}, 1 \mathrm{H}), 3.18(\mathrm{t}, J=8.9$ $\mathrm{Hz}, 1 \mathrm{H}), 2.48(\mathrm{ddd}, J=12.8,5.2,2.1 \mathrm{~Hz}, 1 \mathrm{H}), 2.24-2.14(\mathrm{~m}, 1 \mathrm{H}), 2.14-2.04(\mathrm{~m}, 2 \mathrm{H}), 1.83-1.73(\mathrm{~m}, 1 \mathrm{H})$, $1.73-1.68(\mathrm{~m}, 1 \mathrm{H}), 1.33(\mathrm{~d}, J=6.1 \mathrm{~Hz}, 3 \mathrm{H}), 1.11(\mathrm{~d}, J=6.6 \mathrm{~Hz}, 3 \mathrm{H})$.

${ }^{13} \mathrm{C}$ NMR $\left(126 \mathrm{MHz}, \mathrm{CDCl}_{3}\right) \delta 154.52,151.49,138.66,136.05,133.44,133.13,128.54,128.33,128.24$, $128.03,127.86,127.83,126.51,126.23,126.00,125.95,117.66,114.66,101.61,96.64,83.75,79.47$, $76.13,75.40,71.50,71.46,66.94,55.81,37.23,24.94,24.61,18.40,17.38$.

LRMS (ESI, pos. ion): $m / z$ calculated for $\mathrm{C}_{37} \mathrm{H}_{42} \mathrm{O}{ }_{7} \mathrm{Na}(\mathrm{M}+\mathrm{Na}$ ) 621.28 , found: 621.55

HRMS (TOF MS ES+): $\mathrm{m} / z$ calculated for $\mathrm{C}_{37} \mathrm{H}_{42} \mathrm{O}_{7} \mathrm{Na}(\mathrm{M}+\mathrm{Na})$ 621.2828, found: 621.2838

$[\alpha]_{\lambda}^{23}=-41.0802\left(\mathrm{c}=1.08, \mathrm{CH}_{2} \mathrm{Cl}_{2}\right)$ 


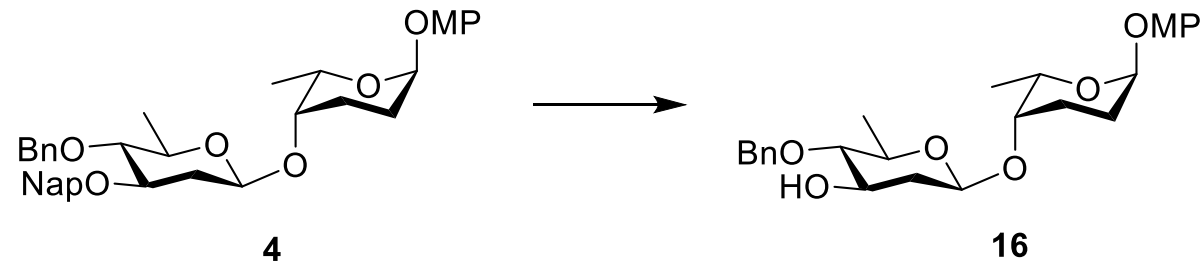

p-Methoxyphenyl 2,3-dideoxy-4-0-(2-deoxy-4-O-benzyl- $\beta$-D-rhamnopyranosyl)- $\alpha$-L-

fucopyranoside Compound 4 (747 mg, $1.25 \mathrm{mmol}$ ) and beta-pinene $(0.66 \mathrm{~mL}, 4.2 \mathrm{mmol})$ were dissolved in $120 \mathrm{~mL}$ dichloromethane and $6 \mathrm{~mL}$ water. DDQ (566 mg, $2.49 \mathrm{mmol}$ ) was added as a solid and the reaction was stirred at room temperature. After 90 minutes, the reaction was diluted in $150 \mathrm{~mL}$ dichloromethane and washed with $2 \mathrm{M}$ sodium hydroxide $(2 \times 200 \mathrm{~mL})$. The aqueous washings were back-extracted with dichloromethane $(1 \times 150 \mathrm{~mL})$. The combined organic layers were washed with saturated sodium bicarbonate $(1 \times 150 \mathrm{~mL})$ followed by water $(1 \times 150 \mathrm{~mL})$. The organic layer was dried with sodium sulfate, filtered through cotton, and concentrated under reduced pressure. The crude was purified by flash chromatography ( $25 \%$ to $30 \%$ ethyl acetate:hexanes) to afford compound $\mathbf{1 6}$ as an offwhite solid.

${ }^{1} \mathrm{H}$ NMR $(500 \mathrm{MHz}$, Chloroform- $d) \delta 7.41-7.28(\mathrm{~m}, 5 \mathrm{H}), 7.04-6.97(\mathrm{~m}, 2 \mathrm{H}), 6.86-6.78(\mathrm{~m}, 2 \mathrm{H}), 5.47(\mathrm{~d}$, $J=2.9 \mathrm{~Hz}, 1 \mathrm{H}), 4.78(\mathrm{~d}, J=11.4 \mathrm{~Hz}, 1 \mathrm{H}), 4.71(\mathrm{~d}, J=11.3 \mathrm{~Hz}, 1 \mathrm{H}), 4.51(\mathrm{dd}, J=9.6,2.0 \mathrm{~Hz}, 1 \mathrm{H}), 4.01(\mathrm{qd}, J$ $=6.6,1.5 \mathrm{~Hz}, 1 \mathrm{H}), 3.77(\mathrm{~s}, 3 \mathrm{H}), 3.70(\mathrm{dddd}, J=11.8,8.6,5.1,3.4 \mathrm{~Hz}, 1 \mathrm{H}), 3.54(\mathrm{~d}, J=3.5 \mathrm{~Hz}, 1 \mathrm{H}), 3.32(\mathrm{dq}$, $J=9.2,6.2 \mathrm{~Hz}, 1 \mathrm{H}), 3.02(\mathrm{t}, J=8.9 \mathrm{~Hz}, 1 \mathrm{H}), 2.29(\mathrm{ddd}, J=12.6,5.1,2.0 \mathrm{~Hz}, 1 \mathrm{H}), 2.24-2.03(\mathrm{~m}, 4 \mathrm{H}), 1.79-$ $1.71(\mathrm{~m}, 1 \mathrm{H}), 1.74-1.67(\mathrm{~m}, 1 \mathrm{H}), 1.37(\mathrm{~d}, J=6.2 \mathrm{~Hz}, 3 \mathrm{H}), 1.12(\mathrm{~d}, J=6.5 \mathrm{~Hz}, 3 \mathrm{H})$.

${ }^{13} \mathrm{C} \mathrm{NMR}\left(126 \mathrm{MHz}, \mathrm{CDCl}_{3}\right) \delta 154.52,151.48,138.36,128.82,128.24,128.13,117.64,114.66,101.70,96.60,85.96$, $76.26,75.27,71.54,71.35,66.92,55.81,39.12,24.91,24.59,18.52,17.29$.

LRMS (ESI, pos. ion): $\mathrm{m} / \mathrm{z}$ calculated for $\mathrm{C}_{26} \mathrm{H}_{34} \mathrm{O}_{7} \mathrm{Na}(\mathrm{M}+\mathrm{Na}): 481.22$, Found: 481.22

HRMS (TOF Es+): $\mathrm{m} / \mathrm{z}$ calculated for $\mathrm{C}_{26} \mathrm{H}_{34} \mathrm{O}_{7} \mathrm{Na}(\mathrm{M}+\mathrm{Na}): 481.2202$ Found: 481.2207

$[\alpha]_{\lambda}{ }^{23}=-20.68\left(\mathrm{c}=1.37, \mathrm{CH}_{2} \mathrm{Cl}_{2}\right)$

Mp: $133-134{ }^{\circ} \mathrm{C}$

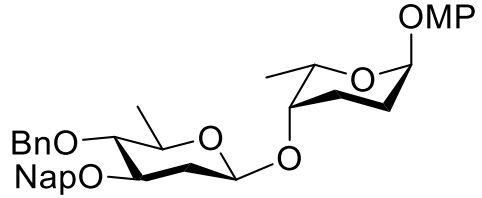

4

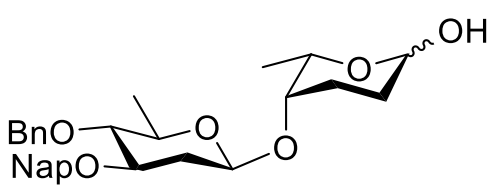

17

2,3-dideoxy-4-0-(2,6-dideoxy-3-0-(2-napthylmethyl)-4-O-benzyl-ß-D-glucopyranosyl)-Lfucopyranoside Compound 4 (200 mg, $0.334 \mathrm{mmol}$ ) was dissolved in $17.7 \mathrm{~mL}$ acetonitrile and $1.8 \mathrm{~mL}$ water. Ceric ammonium nitrate $(366 \mathrm{mg}, 0.668 \mathrm{mmol}$ ) was added as a solid and the reaction was let to stir at room temperature. After five minutes, the reaction was neutralized by pouring over $100 \mathrm{~mL}$ saturated sodium bicarbonate. The mixture was extracted with dichloromethane $(4 \times 60 \mathrm{~mL})$. The 
organic layer was washed with water $(1 \times 50 \mathrm{~mL}), 10 \%$ sodium sulfite $(1 \times 20 \mathrm{~mL})$, and brine $(1 \times 50 \mathrm{~mL})$. The organic layer was dried with sodium sulfate, filtered through cotton, and concentrated under reduced pressure. The crude was purified by flash chromatography (10\% to $40 \%$ ethyl acetate:hexanes) to afford compound 17 was a white foam (153 mg, 93\%, $\alpha: \beta=1.3: 1$ ).

${ }^{1} \mathrm{H}$ NMR $(500 \mathrm{MHz}$, Chloroform-d) $\delta 7.86-7.73(\mathrm{~m}, 8 \mathrm{H}), 7.46(\mathrm{~m} 6 \mathrm{H}), 7.37-7.27(\mathrm{~m}, 10 \mathrm{H}), 5.32(\mathrm{~s}, 1 \mathrm{H})$, $4.98(\mathrm{~d}, J=10.9 \mathrm{~Hz}, 2 \mathrm{H}), 4.85(\mathrm{~d}, J=11.8 \mathrm{~Hz}, 2 \mathrm{H}), 4.78-4.65(\mathrm{~m}, 5 \mathrm{H}), 4.46-4.39(\mathrm{~m}, 2 \mathrm{H}), 4.17-4.09(\mathrm{~m}$, $1 \mathrm{H}), 3.71-3.58(\mathrm{~m}, 3 \mathrm{H}), 3.50(\mathrm{~s}, 1 \mathrm{H}), 3.39(\mathrm{~s}, 1 \mathrm{H}), 3.35-3.26(\mathrm{~m}, 2 \mathrm{H}), 3.21-3.14(\mathrm{~m}, 2 \mathrm{H}), 2.77(\mathrm{~d}, J=7.8$ $\mathrm{Hz}, 1 \mathrm{H}), 2.50-2.39(\mathrm{~m}, 3 \mathrm{H}), 2.26-2.18(\mathrm{~m}, 1 \mathrm{H}), 2.15-1.94(\mathrm{~m}, 3 \mathrm{H}), 1.81-1.69(\mathrm{~m}, 4 \mathrm{H}), 1.69-1.59(\mathrm{~m}$, $1 \mathrm{H}), 1.31$ (dd, $J=6.2,3.0 \mathrm{~Hz}, 6 \mathrm{H}), 1.23(\mathrm{~d}, J=6.4 \mathrm{~Hz}, 3 \mathrm{H}), 1.15(\mathrm{~d}, J=6.6 \mathrm{~Hz}, 3 \mathrm{H})$.

${ }^{13} \mathrm{C}$ NMR $(126 \mathrm{MHz}$, Chloroform-d) $\delta 138.83-138.61(\mathrm{~m}), 133.48,128.53,128.33,128.23,128.04$, $127.84,126.50,126.23,126.00,125.95,101.67,101.54,96.51,91.99,83.79,83.76,79.51,79.46,76.26$, $75.38,74.96,73.94,71.50,71.48,66.30,37.27,37.22,28.37,24.60,24.30,18.40,17.48,17.37$.

LRMS (ESI, pos. ion): 515.27

HRMS (TOF ES+): $\mathrm{m} / \mathrm{z}$ calculated for $\mathrm{C}_{30} \mathrm{H}_{36} \mathrm{O}_{6} \mathrm{Na}(\mathrm{M}+\mathrm{Na}): 515.2410$, Found: 515.2415

$[\alpha]_{\lambda}^{23}\left(\mathrm{c}=0.78, \mathrm{CH}_{2} \mathrm{Cl}_{2}\right)=-20.14$

m.p.: $53-54{ }^{\circ} \mathrm{C}$

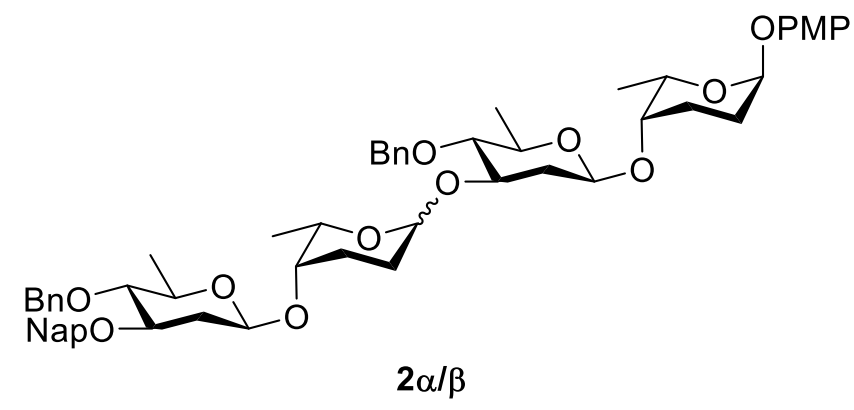

p-methoxyphenyl-2,3-dideoxy-4-0-(2-deoxy-3-0-(2,3-dideoxy-4-0-(2-deoxy-3-0-(2napthylmethyl)-4-O-benzyl- $\beta$-D-rhamnopyranosyl)- $\alpha / \beta$-L-fucopyranosyl)-4-O-benzyl- $\beta$-Drhamnpyranosyl)- $\alpha$-L-fucopyranoside Compound 17 (107 mg, $0.218 \mathrm{mmol}$ ) and DTBMP (45 mg, 0.218 $\mathrm{mmol}$ ) were dissolved in $1.9 \mathrm{~mL} \mathrm{THF}$ and cooled to $-78^{\circ} \mathrm{C}$. KHMDS ( $1 \mathrm{M}$ in THF, $0.22 \mathrm{~mL}, 0.218 \mathrm{mmol}$ ) was added slowly and the reaction was stirred at $-78{ }^{\circ} \mathrm{C}$ for 15 minutes. Trisyl chloride $(66 \mathrm{mg}, 0.218 \mathrm{mmol})$ was dissolved in $0.55 \mathrm{~mL} \mathrm{THF}$ and added dropwise. The reaction was stirred at $-78^{\circ} \mathrm{C}$ for 1 hour. Meanwhile, compound 16 (50 mg, $0.1090 \mathrm{mmol}$ ) was dissolved in $0.52 \mathrm{~mL}$ THF and cooled to $-78{ }^{\circ} \mathrm{C}$. KHMDS (1M in THF, $0.11 \mathrm{~mL}, 0.1090 \mathrm{mmol}$ ) was added dropwise and the solution was stirred at $-78^{\circ} \mathrm{C}$ for 15 minutes. Compound $\mathbf{1 6}$ was then added into the primary reaction vessel and the reaction was stirred at $-78{ }^{\circ} \mathrm{C}$ for 2 hours. The reaction was quenched with $0.5 \mathrm{~mL}$ saturated ammonium chloride and poured over water $(30 \mathrm{~mL})$. The mixture was extracted with diethyl ether $(3 \times 75 \mathrm{~mL})$ and the combined organic extracts were washed with water $(40 \mathrm{~mL})$, dried with sodium sulfate, filtered through cotton, and the solvent removed under reduced pressure. The resulting crude was purified by flash 
chromatography (ethyl acetate: hexanes $20 \%$ to $60 \%$ ) to afford compound $\mathbf{2} \boldsymbol{\alpha} / \boldsymbol{\beta}$ as a white foam as an inseparable mixture of anomers ( $54.4 \mathrm{mg}, 54 \%, \alpha: \beta=5: 1$ ).

${ }^{1} \mathrm{H}$ NMR $(500 \mathrm{MHz}$, Chloroform-d) $\delta 7.85-7.72(\mathrm{~m}, 4 \mathrm{H}), 7.50-7.43(\mathrm{~m}, 3 \mathrm{H}), 7.37-7.25(\mathrm{~m}, 10 \mathrm{H}), 7.04-$ $6.97(\mathrm{~m}, 2 \mathrm{H}), 6.85-6.78(\mathrm{~m}, 2 \mathrm{H}), 5.45(\mathrm{~s}, 1 \mathrm{H}), 5.04(\mathrm{~d}, J=3.2 \mathrm{~Hz}, 1 \mathrm{H}), 5.01-4.96(\mathrm{~m}, 1 \mathrm{H}), 4.90(\mathrm{~d}, J=$ $11.2 \mathrm{~Hz}, 1 \mathrm{H}), 4.88-4.81(\mathrm{~m}, 1 \mathrm{H}), 4.74(\mathrm{~d}, J=11.9 \mathrm{~Hz}, 1 \mathrm{H}), 4.68(\mathrm{dd}, J=11.1,2.0 \mathrm{~Hz}, 2 \mathrm{H}), 4.64(\mathrm{dd}, J=$ $11.2,2.3 \mathrm{~Hz}, 1 \mathrm{H}), 4.50-4.43(\mathrm{~m}, 1 \mathrm{H}), 4.42-4.34(\mathrm{~m}, 1 \mathrm{H}), 4.04-3.97(\mathrm{~m}, 1 \mathrm{H}), 3.98-3.93(\mathrm{~m}, 1 \mathrm{H}), 3.85$ (ddd, $J=11.5,8.9,4.9 \mathrm{~Hz}, 1 \mathrm{H}), 3.77(\mathrm{~s}, 4 \mathrm{H}), 3.69-3.60(\mathrm{~m}, 1 \mathrm{H}), 3.55-3.51(\mathrm{~m}, 1 \mathrm{H}), 3.38-3.23(\mathrm{~m}, 4 \mathrm{H})$, $3.17(\mathrm{t}, J=8.9 \mathrm{~Hz}, 1 \mathrm{H}), 3.16-3.06(\mathrm{~m}, 1 \mathrm{H}), 2.51-2.39(\mathrm{~m}, 3 \mathrm{H}), 2.24-2.02(\mathrm{~m}, 4 \mathrm{H}), 2.02-1.88(\mathrm{~m}, 1 \mathrm{H})$, $1.80-1.67(\mathrm{~m}, 3 \mathrm{H}), 1.62-1.51(\mathrm{~m}, 1 \mathrm{H}), 1.51-1.44(\mathrm{~m}, 1 \mathrm{H}), 1.33-1.27(\mathrm{~m}, 6 \mathrm{H}), 1.19(\mathrm{~d}, J=6.4 \mathrm{~Hz}, 1 \mathrm{H})$, $1.15-1.08(\mathrm{~m}, 4 \mathrm{H}), 1.03(\mathrm{~d}, J=6.5 \mathrm{~Hz}, 3 \mathrm{H})$.

${ }^{13} \mathrm{C}$ NMR (126 MHz, Chloroform-d) $\delta 151.53,138.70,136.08,133.46,128.53,128.48,128.32,128.23$, $128.03,127.83,127.76,126.49,126.22,125.99,125.95,117.69,114.69,101.62,96.67,92.06,83.76$, $83.06,79.48,76.26,76.22,75.38,75.32,73.15,71.51,71.48,71.45,66.97,66.07,55.82,37.19,35.73$, $25.08,24.91,24.62,24.32,18.40,17.37,17.30$.

LRMS (ESI, pos. ion): $\mathrm{m} / \mathrm{z}$ calculated for $\mathrm{C}_{56} \mathrm{H}_{68} \mathrm{O}_{12} \mathrm{Na}(\mathrm{M}+\mathrm{Na})$ : 955.46 , Found: 955.46

HRMS (TOF MS ES+): $\mathrm{m} / \mathrm{z}$ calculated for $\mathrm{C}_{56} \mathrm{H}_{68} \mathrm{O}_{12} \mathrm{Na}(\mathrm{M}+\mathrm{Na}): 955.4608$, Found: 955.4606 
S2.7 Glycosylation with rhodinose donors

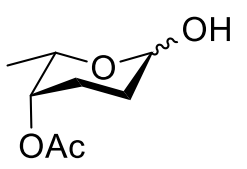

3

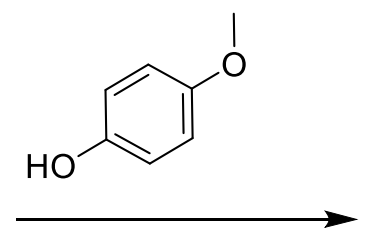<smiles>COc1ccc(O[C@@H]2CC[C@H](OC(C)=O)[C@H](C)O2)cc1</smiles>

20

p-methoxyphenyl 2,3-dideoxy-4-0-acetyl- $\alpha$-L-fucopyranoside Compound 3 (584 mg, 3.39

$\mathrm{mmol}$ ) and TTBP ( $842 \mathrm{mg}, 3.39 \mathrm{mmol}$ ) were dissolved in $26 \mathrm{~mL}$ THF and cooled to $-78^{\circ} \mathrm{C}$. KHMDS (1M in THF, $3.39 \mathrm{~mL}, 3.39 \mathrm{mmol}$ ) was added slowly and the reaction was stirred at $-78{ }^{\circ} \mathrm{C}$ for 15 minutes. Trisyl chloride $(1.03 \mathrm{~g}, 3.39 \mathrm{mmol})$ in $14 \mathrm{~mL}$ THF was added dropwise into the reaction and stirred at $-78{ }^{\circ} \mathrm{C}$ for 30 minutes. Meanwhile in a separate flask, p-methoxyphenol $(280 \mathrm{mg}, 2.26 \mathrm{mmol})$ was dissolved in 8.6 $\mathrm{mL} \mathrm{THF}$ and cooled to $-78^{\circ} \mathrm{C}$. KHMDS (1M in THF, $2.26 \mathrm{~mL}, 2.26 \mathrm{mmol}$ ) was added to the $\mathrm{p}$ methoxyphenol and stirred at $-78^{\circ} \mathrm{C}$ for 15 minutes. The solution of $\mathrm{p}$-methoxyphenol was added into the primary reaction vessel and the reaction was stirred while slowly warming to room temperature. After 5 hours, the reaction was quenched with $0.5 \mathrm{~mL}$ saturated ammonium chloride and poured over $\sim 100 \mathrm{~mL}$ of water. The water was extracted with diethyl ether $(3 \times 100 \mathrm{~mL})$ and the combined organic layers were washed with water $(100 \mathrm{~mL})$, dried over sodium sulfate, filtered through cotton, and the solvent removed under reduced pressure. The resulting crude mixture was purified by flash chromatography (ethyl acetate:hexanes 15\%) to afford compound 20 as a while solid (398 mg, 63\% yield) as a single $\alpha$-anomer.

${ }^{1} \mathrm{H}$ NMR $(500 \mathrm{MHz}$, Chloroform-d) $\delta 7.04-6.96(\mathrm{~m}, 2 \mathrm{H}), 6.86-6.79(\mathrm{~m}, 2 \mathrm{H}), 5.49(\mathrm{~d}, J=3.3 \mathrm{~Hz}, 1 \mathrm{H}), 4.88$ $(\mathrm{s}, 1 \mathrm{H}), 4.14(\mathrm{qd}, J=6.6,1.6 \mathrm{~Hz}, 1 \mathrm{H}), 3.77(\mathrm{~s}, 3 \mathrm{H}), 2.31-2.20(\mathrm{~m}, 1 \mathrm{H}), 2.15(\mathrm{~s}, 3 \mathrm{H}), 2.12-2.01(\mathrm{~m}, 1 \mathrm{H})$, $1.94-1.86(\mathrm{~m}, 1 \mathrm{H}), 1.82-1.74(\mathrm{~m}, 1 \mathrm{H}), 1.09(\mathrm{~d}, J=6.6 \mathrm{~Hz}, 3 \mathrm{H})$.

${ }^{13} \mathrm{C}$ NMR $\left(126 \mathrm{MHz}, \mathrm{CDCl}_{3}\right) \delta$ 170.93, 154.72, 151.22, 117.64, 114.73, 96.33, 69.47, 65.89, 55.81, 24.41, 23.03, 21.24, 17.20.

HRMS (TOF ES+): $\mathrm{m} / \mathrm{z}$ calculated for $\mathrm{C}_{15} \mathrm{H}_{20} \mathrm{O}_{5} \mathrm{Na}(\mathrm{M}+\mathrm{Na}): 303.1208$, Found: 303.1203

m.p.: $92-93^{\circ} \mathrm{C}$

$[\alpha]_{\lambda}^{23}\left(\mathrm{c}=0.95, \mathrm{CH}_{2} \mathrm{Cl}_{2}\right)=-35.89$

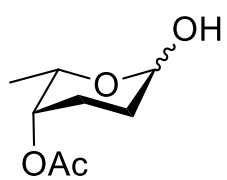

3
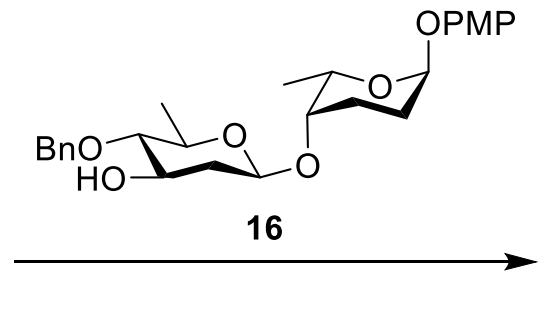

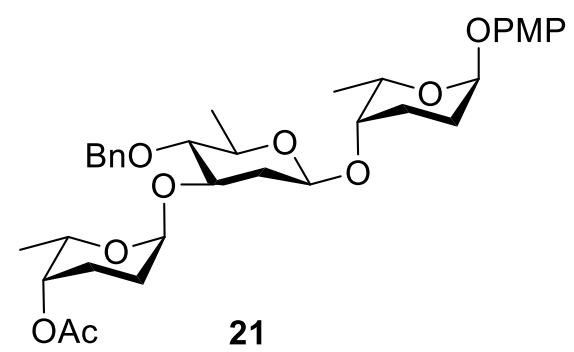


p-methoxyphenyl 2,3-dideoxy-4-0-(2-deoxy-3-0-(2,3-dideoxy-4-0-acetyl- $\alpha$-L-fucopyranosyl)-4O-benzyl- $\beta$-D-rhamnopyranosyl)- $\boldsymbol{\alpha}$-L-fucopyranoside Compound 3 ( $389 \mathrm{mg}, 2.23 \mathrm{mmol}$ ) and TTBP (555 $\mathrm{mg}, 2.23 \mathrm{mmol}$ ) were dissolved in $20.1 \mathrm{~mL}$ THF and cooled to $-78^{\circ} \mathrm{C}$. KHMDS (1M in THF, $2.2 \mathrm{~mL}, 2.2$ $\mathrm{mmol}$ ) was added slowly and the reaction was then stirred at $-78{ }^{\circ} \mathrm{C}$ for 15 minutes. Trisyl chloride (676 $\mathrm{mg}, 2.23 \mathrm{mmol}$ ) was dissolved in $5.6 \mathrm{~mL}$ THF and added slowly into the reaction. The reaction was then stirred at $-78{ }^{\circ} \mathrm{C}$ for 30 minutes. Meanwhile, compound 16 (512 mg, $1.11 \mathrm{mmol}$ ) was dissolved in $4.3 \mathrm{~mL}$ THF and cooled to $-78^{\circ} \mathrm{C}$. KHMDS ( $1 \mathrm{M}$ in THF, $\left.1.1 \mathrm{~mL}, 1.1 \mathrm{mmol}\right)$ was added slowly and the reaction was stirred at $-78^{\circ} \mathrm{C}$ for fifteen minutes. Compound 16 was then added into the primary reaction vessel and allowed to stir while gradually warming from $-78^{\circ} \mathrm{C}$ to room temperature. After 4 hours, the reaction was quenched with $1.5 \mathrm{~mL}$ saturated ammonium chloride and poured over water (100 mL). The mixture was extracted with diethyl ether $(3 \times 75 \mathrm{~mL})$ and the combined organic layers were washed with water $(100 \mathrm{~mL})$, dried over sodium sulfate, filtered through cotton, and the solvent removed under reduced pressure. The crude mixture was purified by flash chromatography ( $20 \%$ to $30 \%$ ethyl acetate: hexanes) to afford compound 21 as a white foam as a single $\alpha$-anomer (366 mg, 59\%).

${ }^{1} \mathrm{H}$ NMR $(500 \mathrm{MHz}$, Chloroform-d) $\delta 7.38-7.27(\mathrm{~m}, 5 \mathrm{H}), 7.04-6.97(\mathrm{~m}, 2 \mathrm{H}), 6.85-6.78(\mathrm{~m}, 2 \mathrm{H}), 5.46(\mathrm{~s}$, $1 \mathrm{H}), 5.05(\mathrm{~s}, 1 \mathrm{H}), 4.86(\mathrm{~d}, J=11.0 \mathrm{~Hz}, 1 \mathrm{H}), 4.70(\mathrm{~d}, J=11.0 \mathrm{~Hz}, 1 \mathrm{H}), 4.63(\mathrm{~s}, 1 \mathrm{H}), 4.49(\mathrm{dd}, J=9.7,2.0 \mathrm{~Hz}$, $1 \mathrm{H}), 4.07(\mathrm{q}, J=6.4 \mathrm{~Hz}, 1 \mathrm{H}), 4.01(\mathrm{q}, J=6.6 \mathrm{~Hz}, 1 \mathrm{H}), 3.85$ (ddd, $J=11.5,8.9,4.9 \mathrm{~Hz}, 1 \mathrm{H}$ ), $3.77(\mathrm{~s}, 3 \mathrm{H}), 3.54$ $(\mathrm{s}, 1 \mathrm{H}), 3.36(\mathrm{dq}, J=9.2,6.2 \mathrm{~Hz}, 1 \mathrm{H}), 3.12(\mathrm{t}, J=9.1 \mathrm{~Hz}, 1 \mathrm{H}), 2.47(\mathrm{ddd}, J=12.6,5.1,1.9 \mathrm{~Hz}, 1 \mathrm{H}), 2.26-$ $1.91(\mathrm{~m}, 8 \mathrm{H}), 1.85-1.77(\mathrm{~m}, 1 \mathrm{H}), 1.75-1.68(\mathrm{~m}, 1 \mathrm{H}), 1.64-1.50(\mathrm{~m}, 2 \mathrm{H}), 1.33(\mathrm{~d}, J=6.2 \mathrm{~Hz}, 3 \mathrm{H}), 1.11$ (d, $J=6.5 \mathrm{~Hz}, 3 \mathrm{H}), 0.97(\mathrm{~d}, J=6.5 \mathrm{~Hz}, 3 \mathrm{H})$.

${ }^{13} \mathrm{C}$ NMR $(126 \mathrm{MHz}$, Chloroform-d) $\delta 170.94,154.53,151.48,138.39,128.59,127.95,127.76,117.66$, $114.66,101.57,96.63,91.80,83.13,76.26,75.53,73.18,71.55,69.54,66.91,64.95,55.79,35.67,24.92$, $24.60,24.10,23.15,21.22,18.39,17.36,17.05$.

LRMS (ESI, pos. ion): $\mathrm{m} / \mathrm{z}$ calculated for $\mathrm{C}_{34} \mathrm{H}_{46} \mathrm{O}_{10} \mathrm{Na}(\mathrm{M}+\mathrm{Na}): 637.30$, Found: 637.37

HRMS (TOF ES+): $\mathrm{m} / \mathrm{z}$ calculated for $\mathrm{C}_{34} \mathrm{H}_{46} \mathrm{O}_{10} \mathrm{Na}(\mathrm{M}+\mathrm{Na}): 637.2989$, Found: 637.2997

M.p.: $59-60^{\circ} \mathrm{C}$

$[\alpha]_{\lambda}^{23}:\left(c=1.34, \mathrm{CH}_{2} \mathrm{Cl}_{2}\right):-46.77$

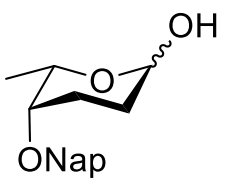

19

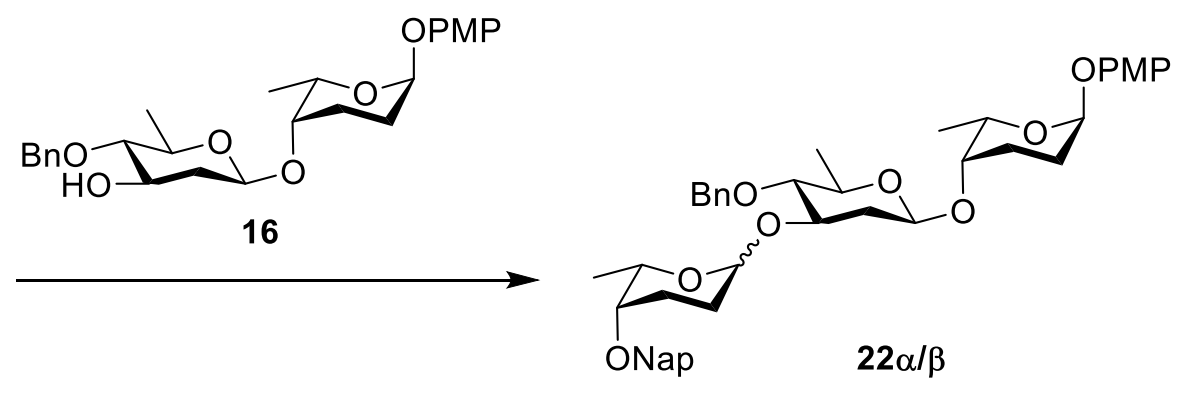


p-methoxyphenyl 2,3-dideoxy-4-0-(2-deoxy-3-0-(2,3-dideoxy-4-0-(2-napthylmethyl)- $\alpha / \beta-L-$ fucopyranosyl)-4-O-benzyl- $\beta$-D-rhamnopyranosyl)- $\alpha$-L-fucopyranoside Compound 19 (59.4 mg, 0.218 $\mathrm{mmol}$ ) and TTBP $(54.2 \mathrm{mg}, 0.218 \mathrm{mmol})$ were dissolved in $1.96 \mathrm{~mL}$ THF and cooled to $-78{ }^{\circ} \mathrm{C}$. KHMDS (1 $\mathrm{M}$ in THF) (0.22 mL, $0.22 \mathrm{mmol}$ ) was added dropwise and stirred at $-78^{\circ} \mathrm{C}$ for 15 minutes. Trisyl chloride (66 mg, $0.2181 \mathrm{mmol}$ ) was dissolved in $0.55 \mathrm{~mL}$ THF and added dropwise to the reaction, which was stirred for 1 hour at $-78{ }^{\circ} \mathrm{C}$. Meanwhile, compound 16 (50 mg, $0.1090 \mathrm{~mol}$ ) was dissolved in $0.55 \mathrm{~mL}$ THF and cooled to $-78^{\circ} \mathrm{C}$. KHMDS ( $1 \mathrm{M}$ in THF, $0.11 \mathrm{~mL}, 0.11 \mathrm{mmol}$ ) was added dropwise and the reaction was stirred at $-78{ }^{\circ} \mathrm{C}$ for 15 minutes. The solution of 16 was added dropwise into 19 and the reaction was stirred at $-78^{\circ} \mathrm{C}$ for 2.5 hours. The reaction was quenched by the addition of $0.5 \mathrm{~mL}$ saturated ammonium chloride. The reaction was then poured over $\sim 25 \mathrm{~mL}$ water and extracted with diethyl ether $(3 \times 25 \mathrm{~mL})$. The combined organic layers were washed with water $(30 \mathrm{~mL})$, dried over sodium sulfate, filtered through cotton, and the solvent removed under reduced pressure. The crude mixture was purified by flash chromatography (20\% to $60 \%$ ethyl acetate:hexanes) affording compounds $\mathbf{2 2} \alpha$ and $22 \beta$ as white foams ( $36 \mathrm{mg}, \alpha: \beta=5: 1$ ).

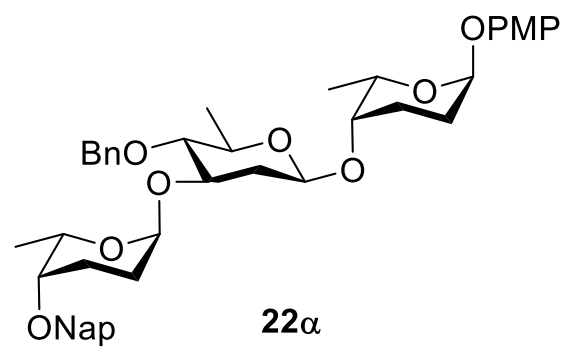

p-methoxyphenyl 2,3-dideoxy-4-0-(2-deoxy-3-0-(2,3-dideoxy-4-0-(2-napthylmethyl)- $\alpha$-Lfucopyranosyl)-4-0-benzyl- $\beta$-D-rhamnopyranosyl)- $\alpha$-L-fucopyranoside

${ }^{1} \mathrm{H}$ NMR $(500 \mathrm{MHz}$, Chloroform-d) $87.91-7.71(\mathrm{~m}, 4 \mathrm{H}), 7.55-7.42(\mathrm{~m}, 3 \mathrm{H}), 7.29-7.23(\mathrm{~m}, 4 \mathrm{H}), 7.23-$ $7.15(\mathrm{~m}, 1 \mathrm{H}), 7.03-6.96(\mathrm{~m}, 2 \mathrm{H}), 6.84-6.77(\mathrm{~m}, 2 \mathrm{H}), 5.45(\mathrm{~s}, 1 \mathrm{H}), 5.06(\mathrm{~s}, 1 \mathrm{H}), 4.87(\mathrm{~d}, J=11.1 \mathrm{~Hz}, 1 \mathrm{H})$, $4.81(\mathrm{~d}, J=12.3 \mathrm{~Hz}, 1 \mathrm{H}), 4.68(\mathrm{~d}, J=11.1 \mathrm{~Hz}, 1 \mathrm{H}), 4.57(\mathrm{~d}, J=12.3 \mathrm{~Hz}, 1 \mathrm{H}), 4.48(\mathrm{dd}, J=9.6,2.1 \mathrm{~Hz}, 1 \mathrm{H})$, $4.00(\mathrm{q}, J=6.6 \mathrm{~Hz}, 2 \mathrm{H}), 3.91-3.83(\mathrm{~m}, 1 \mathrm{H}), 3.76(\mathrm{~s}, 3 \mathrm{H}), 3.53(\mathrm{~s}, 1 \mathrm{H}), 3.34(\mathrm{dq}, J=12.1,6.4 \mathrm{~Hz}, 1 \mathrm{H}), 3.14$ (s, 1H), $3.10(\mathrm{t}, J=9.0 \mathrm{~Hz}, 1 \mathrm{H}), 2.47(\mathrm{dd}, J=12.5,4.8 \mathrm{~Hz}, 1 \mathrm{H}), 2.24-2.02(\mathrm{~m}, 4 \mathrm{H}), 1.99-1.92(\mathrm{~m}, 1 \mathrm{H})$, $1.88-1.78(\mathrm{~m}, 1 \mathrm{H}), 1.69(\mathrm{~d}, J=12.2 \mathrm{~Hz}, 1 \mathrm{H}), 1.62-1.46(\mathrm{~m}, 2 \mathrm{H}), 1.29(\mathrm{~d}, J=6.2 \mathrm{~Hz}, 3 \mathrm{H}), 1.13-1.06(\mathrm{~m}$, $6 \mathrm{H})$.

${ }^{13} \mathrm{C} \mathrm{NMR}\left(126 \mathrm{MHz}, \mathrm{CDCl}_{3}\right) \delta 154.55,151.52,138.61,136.31,133.38,133.12,128.43,128.19,127.98$, $127.84,127.80,127.73,126.55,126.21,126.12,125.95,117.69,114.68,101.62,96.66,92.00,83.12$, 76.23, 75.35, 73.55, 73.07, 71.51, 71.19, 66.96, 66.49, 55.81, 35.76, 24.91, 24.62, 24.07, 21.63, 18.40, $17.40,14.35$.

LRMS (ESI, pos. ion): $\mathrm{m} / \mathrm{z}$ calculated for $\mathrm{C}_{43} \mathrm{H}_{52} \mathrm{O}_{9} \mathrm{Na}(\mathrm{M}+\mathrm{Na}):$ 735.35, Found: 735.43

HRMS (TOF MS ES+): $\mathrm{m} / \mathrm{z}$ calculated for $\mathrm{C}_{43} \mathrm{H}_{52} \mathrm{O}_{9} \mathrm{Na}(\mathrm{M}+\mathrm{Na}):$ 735.3509, Found: 734.3494

$[\alpha]_{\lambda}^{23}\left(c=3.72, \mathrm{CH}_{2} \mathrm{Cl}_{2}\right)=-33.78$ 


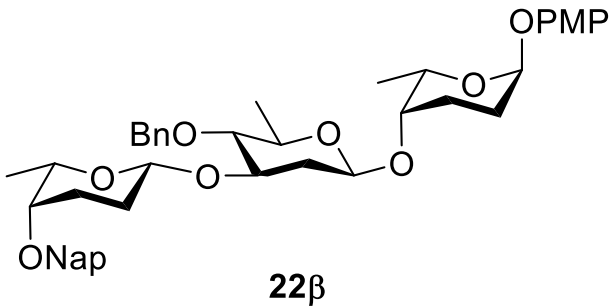

p-methoxyphenyl 2,3-dideoxy-4-0-(2-deoxy-3-0-(2,3-dideoxy-4-0-(2-napthylmethyl)- $\beta$-Lfucopyranosyl)-4-O-benzyl- $\beta$-D-rhamnopyranosyl)- $\alpha$-L-fucopyranoside

${ }^{1} \mathrm{H}$ NMR $(500 \mathrm{MHz}$, Chloroform-d) $\delta 7.91-7.72(\mathrm{~m}, 4 \mathrm{H}), 7.58-7.42(\mathrm{~m}, 3 \mathrm{H}), 7.40-7.26(\mathrm{~m}, 5 \mathrm{H}), 7.03-$ $6.97(\mathrm{~m}, 2 \mathrm{H}), 6.84-6.77(\mathrm{~m}, 2 \mathrm{H}), 5.46(\mathrm{~s}, 1 \mathrm{H}), 4.86-4.79(\mathrm{~m}, 2 \mathrm{H}), 4.71-4.63(\mathrm{~m}, 2 \mathrm{H}), 4.60(\mathrm{~d}, \mathrm{~J}=12.6$ $\mathrm{Hz}, 1 \mathrm{H}), 4.46(\mathrm{dd}, J=9.8,2.0 \mathrm{~Hz}, 1 \mathrm{H}), 3.99(\mathrm{q}, J=6.5 \mathrm{~Hz}, 1 \mathrm{H}), 3.76(\mathrm{~s}, 4 \mathrm{H}), 3.57-3.49(\mathrm{~m}, 2 \mathrm{H}), 3.34-3.25$ $(\mathrm{m}, 1 \mathrm{H}), 3.17(\mathrm{~s}, 1 \mathrm{H}), 3.11(\mathrm{t}, J=9.1 \mathrm{~Hz}, 1 \mathrm{H}), 2.48(\mathrm{ddd}, J=13.1,5.0,1.9 \mathrm{~Hz}, 1 \mathrm{H}), 2.26-2.15(\mathrm{~m}, 1 \mathrm{H}), 2.16$ $-2.06(\mathrm{~m}, 3 \mathrm{H}), 1.93-1.79(\mathrm{~m}, 2 \mathrm{H}), 1.72-1.65(\mathrm{~m}, 1 \mathrm{H}), 1.62-1.55(\mathrm{~m}, 1 \mathrm{H}), 1.45-1.34(\mathrm{~m}, 1 \mathrm{H}), 1.30(\mathrm{~d}$, $J=6.1 \mathrm{~Hz}, 3 \mathrm{H}), 1.25(\mathrm{~d}, J=5.8 \mathrm{~Hz}, 3 \mathrm{H}), 1.12(\mathrm{~d}, J=6.5 \mathrm{~Hz}, 3 \mathrm{H})$.

${ }^{13} \mathrm{C}$ NMR $\left(126 \mathrm{MHz}, \mathrm{CDCl}_{3}\right) \delta 154.49,151.53,138.62,136.28,133.32,133.12,128.54,128.17,128.10$, $127.96,127.86,127.83,126.74,126.32$, 126.18, 125.94, 117.67, 114.65, 103.56, 101.81, 96.66, 84.24, 79.56, 76.07, 75.31, 73.86, 72.29, 71.42, 71.08, 67.03, 55.80, 39.42, 26.46, 25.69, 24.74, 24.55, 18.39, $17.62,17.26$.

LRMS (ESI, pos. ion): $\mathrm{m} / \mathrm{z}$ calculated for $\mathrm{C}_{43} \mathrm{H}_{52} \mathrm{O}_{9} \mathrm{Na}(\mathrm{M}+\mathrm{Na}): 735.35$, Found: 735.41

HRMS (TOF MS ES+): $\mathrm{m} / \mathrm{z}$ calculated for $\mathrm{C}_{43} \mathrm{H}_{52} \mathrm{O}_{9} \mathrm{Na}(\mathrm{M}+\mathrm{Na}):$ 735.3509, Found: 735.3499

$[\alpha]_{\lambda}^{23}\left(\mathrm{c}=2.96, \mathrm{CH}_{2} \mathrm{Cl}_{2}\right)=-7.78$

S2.8 Synthesis of Tetrasaccharide 18

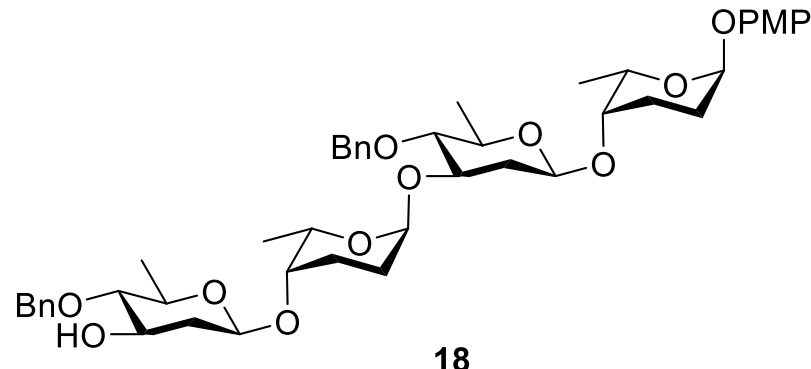

p-methoxyphenyl-2,3-dideoxy-4-0-(2-deoxy-3-0-(2,3-dideoxy-4-0-(2-deoxy-4-O-benzyl- $\beta$-Drhamnopyranosyl)- $\alpha$-L-fucopyranosyl)-4-O-benzyl- $\beta$-D-rhamnpyranosyl)- $\alpha$-L-fucopyranoside Compound $2 \alpha / \beta(527 \mathrm{mg}, 0.565 \mathrm{mmol})$ and $\beta$-pinene $(0.30 \mathrm{~mL}, 1.9 \mathrm{mmol})$ were dissolved in $52 \mathrm{~mL}$ dichloromethane and $2.6 \mathrm{~mL}$ water. DDQ (257 mg, $1.13 \mathrm{mmol}$ ) was added as a solid and the reaction was stirred vigorously for 2 hours. During this time the reaction color changed from dark green to light 
yellow/green. Upon completion, the reaction was diluted over dichloromethane $(75 \mathrm{~mL})$ and washed with $2 \mathrm{M}$ sodium hydroxide $(2 \times 100 \mathrm{~mL})$. The aqueous washes were back-extracted with dichloromethane $(1 \times 50 \mathrm{~mL})$. The combined dichloromethane layers were washed with saturated sodium bicarbonate $(1 \times 50 \mathrm{~mL})$, and water $(1 \times 50 \mathrm{~mL})$. The organic layer was dried with sodium sulfate, filtered through cotton, and the solvent removed under reduced pressure. The crude mixture was purified by flash chromatography (35\% ethyl acetate : hexanes) to afford compound 18 (211 mg, 47\%).

${ }^{1} \mathrm{H}$ NMR $(500 \mathrm{MHz}$, Chloroform-d) $\delta 7.40-7.24(\mathrm{~m}, 10 \mathrm{H}), 7.03-6.96(\mathrm{~m}, 2 \mathrm{H}), 6.84-6.77(\mathrm{~m}, 2 \mathrm{H}), 5.45$ $(\mathrm{s}, 1 \mathrm{H}), 5.03(\mathrm{~d}, J=3.3 \mathrm{~Hz}, 1 \mathrm{H}), 4.91(\mathrm{~d}, J=11.2 \mathrm{~Hz}, 1 \mathrm{H}), 4.77(\mathrm{~d}, J=11.3 \mathrm{~Hz}, 1 \mathrm{H}), 4.73-4.65(\mathrm{~m}, 2 \mathrm{H}), 4.47$ (dd, $J=9.7,1.9 \mathrm{~Hz}, 1 \mathrm{H}$ ), $4.43(\mathrm{dd}, J=9.6,2.0 \mathrm{~Hz}, 1 \mathrm{H}), 4.00(\mathrm{q}, J=6.9 \mathrm{~Hz}, 1 \mathrm{H}), 3.95(\mathrm{q}, J=6.5 \mathrm{~Hz}, 1 \mathrm{H}), 3.85$ (ddd, $J=11.6,8.9,4.9 \mathrm{~Hz}, 1 \mathrm{H}), 3.76(\mathrm{~s}, 3 \mathrm{H}), 3.72-3.62(\mathrm{~m}, 1 \mathrm{H}), 3.52(\mathrm{~s}, 1 \mathrm{H}), 3.38-3.25(\mathrm{~m}, 3 \mathrm{H}), 3.10(\mathrm{t}, J$ $=9.1 \mathrm{~Hz}, 1 \mathrm{H}), 3.00(\mathrm{t}, J=8.9 \mathrm{~Hz}, 1 \mathrm{H}), 2.46(\mathrm{dd}, J=12.1,4.5 \mathrm{~Hz}, 1 \mathrm{H}), 2.28-1.89(\mathrm{~m}, 8 \mathrm{H}), 1.76-1.65(\mathrm{~m}$, $2 \mathrm{H}), 1.63-1.51(\mathrm{~m}, 1 \mathrm{H}), 1.51-1.43(\mathrm{~m}, 1 \mathrm{H}), 1.35(\mathrm{~d}, J=6.2 \mathrm{~Hz}, 3 \mathrm{H}), 1.29(\mathrm{~d}, J=6.2 \mathrm{~Hz}, 3 \mathrm{H}), 1.10(\mathrm{~d}, J=$ $6.5 \mathrm{~Hz}, 3 \mathrm{H}), 1.03(\mathrm{~d}, J=6.5 \mathrm{~Hz}, 3 \mathrm{H})$.

${ }^{13} \mathrm{C}$ NMR (126 MHz, Chloroform-d) $\delta 154.54,151.51,138.69,138.38,128.80,128.48,128.21,128.11$, $127.82,127.76,117.68,114.67,101.66,101.62$, 96.65, 92.02, 85.94, 83.05, 76.37, 76.23, 75.31, 75.23, $73.13,71.55,71.50,71.32,66.95,66.04,55.81,39.11,35.71,25.05,24.90,24.61,24.28,18.52$, 18.38, $17.36,17.21$.

LRMS (ESI, pos. ion): $\mathrm{m} / \mathrm{z}$ calculated for $\mathrm{C}_{45} \mathrm{H}_{60} \mathrm{O}_{12} \mathrm{Na}(\mathrm{M}+\mathrm{Na}): 815.41$, Found: 815.45

HRMS: $\mathrm{m} / \mathrm{z}$ calculated for $\mathrm{C}_{45} \mathrm{H}_{60} \mathrm{O}_{12} \mathrm{Na}(\mathrm{M}+\mathrm{Na}): 815.3982$, Found: 815.3639

$[\alpha]_{\lambda}^{23}\left(\mathrm{c}=0.89, \mathrm{CH}_{2} \mathrm{Cl}_{2}\right):-40.41$

m.p. $73-74{ }^{\circ} \mathrm{C}$

S2.9 Synthesis of pentasaccahrides 23, 24, 1

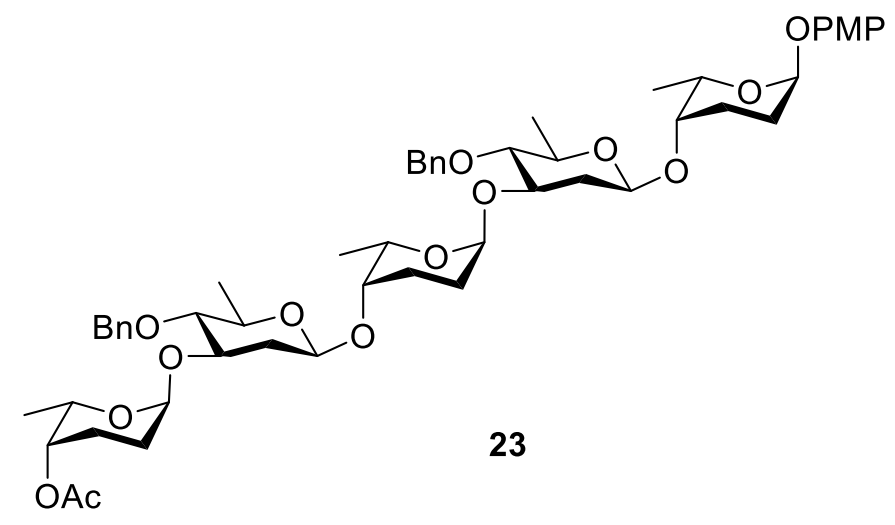


p-Methoxyphenyl 2,3-dideoxy-4-0-(2-deoxy-3-0-(2,3-dideoxy-4-0-(2-deoxy-3-0-(2,3-dideoxy4-0-Acetyl- $\alpha$-L-fucopyranosyl)-4-0-benzyl- $\beta$-D-rhamnopyranosyl)- $\alpha$-L-fucopyranosyl)-4-O-benzyl- $\beta$-Drhamnpyranosyl)- $\alpha$-L-fucopyranoside $A$ stock solution of compound 3 was prepared (128 mg in $6.6 \mathrm{~mL}$ THF). From this solution, $1.13 \mathrm{~mL}(0.126 \mathrm{mmol})$ was added to TTBP (31 $\mathrm{mg}, 0.13 \mathrm{mmol}$ ) and cooled to $78{ }^{\circ} \mathrm{C}$. KHMDS (1M in THF, $0.13 \mathrm{~mL}, 0.13 \mathrm{mmol}$ ) was added slowly and the solution was stirred for 15 minutes at $-78^{\circ} \mathrm{C}$. A stock solution of trisyl chloride was prepared ( $98 \mathrm{mg}$ in $0.82 \mathrm{~mL}$ THF) and cooled to $78{ }^{\circ} \mathrm{C}$. From this solution, $0.32 \mathrm{~mL}(0.13 \mathrm{mmol})$ was added to the reaction which was then allowed to stir for 30 minutes. Meanwhile, a stock solution of 18 was prepared (58 mg in $0.36 \mathrm{~mL}$ THF) and cooled to $78{ }^{\circ} \mathrm{C}$. KHMDS ( $1 \mathrm{M}$ in THF, $0.07 \mathrm{~mL}$ ) was added to the stock solution which was stirred at $-78{ }^{\circ} \mathrm{C}$ for 15 minutes. From the stock solution of $18,0.37 \mathrm{~mL}(0.063 \mathrm{mmol})$ was added to the primary reaction vessel and the reaction was stirred at $-78{ }^{\circ} \mathrm{C}$ for 4 hours. The reaction was quenched with $0.5 \mathrm{~mL}$ saturated ammonium chloride. The reaction was poured over $15 \mathrm{~mL}$ brine solution and extracted with diethyl ether $(3 \times 50 \mathrm{~mL})$. The combined organic layers were washed with water $(50 \mathrm{~mL})$, dried over sodium sulfate, filtered through cotton, and the solvent removed under reduced pressure. The resulting crude mixture was purified by flash chromatography ( $30 \%$ to $50 \%$ ethyl acetate:hexanes) to afford compound 23 as a single $\alpha$-anomer as a white foam. (39.4 mg, 66\%).

${ }^{1} \mathrm{H}$ NMR $(500 \mathrm{MHz}$, Chloroform-d) $\delta 7.38-7.26(\mathrm{~m}, 10 \mathrm{H}), 7.03-6.96(\mathrm{~m}, 2 \mathrm{H}), 6.84-6.77(\mathrm{~m}, 2 \mathrm{H}), 5.45$ $(\mathrm{s}, 1 \mathrm{H}), 5.06-5.00(\mathrm{~m}, 2 \mathrm{H}), 4.90(\mathrm{~d}, J=11.2 \mathrm{~Hz}, 1 \mathrm{H}), 4.85(\mathrm{~d}, J=11.1 \mathrm{~Hz}, 1 \mathrm{H}), 4.72-4.65(\mathrm{~m}, 2 \mathrm{H}), 4.63(\mathrm{~s}$, $1 \mathrm{H}), 4.47(\mathrm{dd}, J=9.7,1.9 \mathrm{~Hz}, 1 \mathrm{H}), 4.40(\mathrm{dd}, J=9.8,1.9 \mathrm{~Hz}, 1 \mathrm{H}), 4.05(\mathrm{q}, J=6.6 \mathrm{~Hz}, 1 \mathrm{H}), 4.03-3.97(\mathrm{~m}$, $1 \mathrm{H}), 3.95(\mathrm{q}, J=7.1,6.6 \mathrm{~Hz}, 1 \mathrm{H}), 3.89-3.78(\mathrm{~m}, 2 \mathrm{H}), 3.76(\mathrm{~s}, 3 \mathrm{H}), 3.53(\mathrm{~s}, 1 \mathrm{H}), 3.38-3.28(\mathrm{~m}, 3 \mathrm{H}), 3.10$ $(\mathrm{t}, J=9.1 \mathrm{~Hz}, 2 \mathrm{H}), 2.50-2.38(\mathrm{~m}, 2 \mathrm{H}), 2.24-1.89(\mathrm{~m}, 11 \mathrm{H}), 1.83-1.76(\mathrm{~m}, 1 \mathrm{H}), 1.73-1.66(\mathrm{~m}, 1 \mathrm{H}), 1.61$ $-1.43(\mathrm{~m}, 4 \mathrm{H}), 1.33-1.27(\mathrm{~m}, 6 \mathrm{H}), 1.11(\mathrm{~d}, J=6.5 \mathrm{~Hz}, 3 \mathrm{H}), 1.02(\mathrm{~d}, J=6.5 \mathrm{~Hz}, 3 \mathrm{H}), 0.96(\mathrm{~d}, J=6.5 \mathrm{~Hz}$, $3 \mathrm{H})$.

${ }^{13} \mathrm{C}$ NMR $(126 \mathrm{MHz}$, Chloroform-d) $\delta 170.93,154.56,151.53,138.69,138.44,128.59,128.49,127.94$, 127.82 , 127.77, 127.76, 117.69, 114.69, 101.62, 101.57, 96.67, 92.03, 91.80, 83.14, 83.07, 76.39, 76.22, $75.51,75.32,73.22,73.14,71.54,71.51,69.56,66.96,66.05,64.96,55.81,35.72,35.64,25.06,24.91$, $24.62,24.31,24.11,23.16,21.21,18.39$ (2C), 17.37, 17.27, 17.05.

LRMS (ESI, pos. ion): $\mathrm{m} / \mathrm{z}$ calculated for $\mathrm{C}_{53} \mathrm{H}_{72} \mathrm{NaO}_{15}$ (M+Na): 971.48 , Found: 971.70

HRMS (TOF MS ES+): $\mathrm{m} / \mathrm{z}$ calculated for $\mathrm{C}_{53} \mathrm{H}_{72} \mathrm{O}_{15} \mathrm{Na}(\mathrm{M}+\mathrm{Na}): 971.4769$, Found: 971.4763

$[\alpha]_{\lambda}{ }^{23}\left(\mathrm{c}=1.99, \mathrm{CH}_{2} \mathrm{Cl}_{2}\right)=-42.71$

m.p. $88-89^{\circ} \mathrm{C}$ 


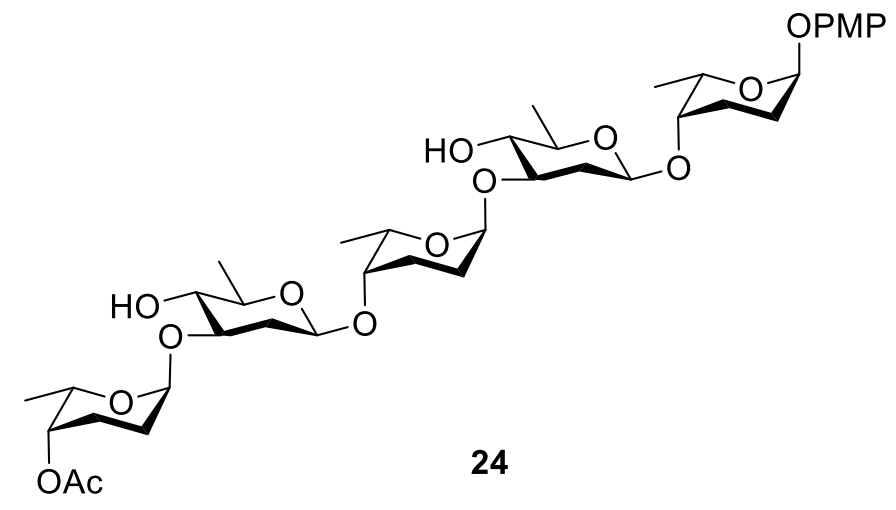

p-Methoxyphenyl 2,3-dideoxy-4-0-(2-deoxy-3-0-(2,3-dideoxy-4-0-(2-deoxy-3-0-(2,3-dideoxy4-O-Acetyl- $\alpha$-L-fucopyranosyl)- $\beta$-D-rhamnopyranosyl)- $\alpha$-L-fucopyranosyl)- $\beta$-D-rhamnpyranosyl)- $\alpha$-Lfucopyranoside Compound $23(10 \mathrm{mg}, 0.011 \mathrm{mmol})$ was dissolved in $7.1 \mathrm{~mL}$ absolute ethanol and 1.5 $\mathrm{mL}$ THF. Roughly $0.5 \mathrm{~g}$ of Raney nickel (slurry in water) was added into the solution and the reaction was stirred at room temperature for 24 hours, at which point an additional $0.5 \mathrm{~g}$ of Raney nickel was added to the reaction. After stirring for an additional 7 hours the reaction was filtered through a pad of Celite with ethanol. The solvent from the filtrate was removed under reduced pressure and the crude was purified by flash chromatography ( $40 \%$ to $70 \%$ ethyl acetate: hexanes) to afford compound $\mathbf{2 4}$ as a clear oil. Residual grease was removed by dissolving 24 in methanol and washing with hexanes (4.9 $\mathrm{mg}, 60 \%$ ).

${ }^{1} \mathrm{H}$ NMR $(500 \mathrm{MHz}$, Chloroform-d) $\delta 7.04-6.97(\mathrm{~m}, 2 \mathrm{H}), 6.85-6.78(\mathrm{~m}, 2 \mathrm{H}), 5.46(\mathrm{~s}, 1 \mathrm{H}), 4.99(\mathrm{~s}, 1 \mathrm{H})$, $4.96(\mathrm{~s}, 1 \mathrm{H}), 4.85(\mathrm{~s}, 1 \mathrm{H}), 4.48(\mathrm{~d}, J=9.8 \mathrm{~Hz}, 2 \mathrm{H}), 4.38(\mathrm{~d}, J=1.5 \mathrm{~Hz}, 1 \mathrm{H}), 4.19$ (qd, J = 6.8, $1.5 \mathrm{~Hz}, 1 \mathrm{H})$, $4.11-4.06(\mathrm{~m}, 2 \mathrm{H}), 4.01(\mathrm{q}, J=6.7,6.2 \mathrm{~Hz}, 1 \mathrm{H}), 3.77(\mathrm{~s}, 3 \mathrm{H}), 3.54(\mathrm{~s}, 2 \mathrm{H}), 3.53-3.44(\mathrm{~m}, 2 \mathrm{H}), 3.29-3.20$ $(\mathrm{m}, 2 \mathrm{H}), 3.14-3.05(\mathrm{~m}, 2 \mathrm{H}), 2.31-1.92(\mathrm{~m}, 13 \mathrm{H}), 1.84-1.77(\mathrm{~m}, 1 \mathrm{H}), 1.77-1.62(\mathrm{~m}, 3 \mathrm{H}), 1.62-1.52$ $(\mathrm{m}, 2 \mathrm{H}), 1.37-1.32(\mathrm{~m}, 6 \mathrm{H}), 1.19(\mathrm{~d}, J=6.5 \mathrm{~Hz}, 3 \mathrm{H}), 1.15(\mathrm{~d}, J=6.5 \mathrm{~Hz}, 3 \mathrm{H}), 1.12(\mathrm{~d}, J=6.5 \mathrm{~Hz}, 3 \mathrm{H})$.

${ }^{13} \mathrm{C} \mathrm{NMR}\left(126 \mathrm{MHz}, \mathrm{CDCl}_{3}\right) \delta 170.80,154.55,151.51,117.70,114.68,101.69,101.45,97.77,97.16,96.68$, $81.14,80.67,76.19,76.04,75.87,75.80,71.94$ (2C), 69.32, 67.67, 66.97, 66.46, 55.82, 37.37, 37.17, $25.25,24.89$ (2C), 24.67, 24.60, 22.83, 21.21, 18.28, 18.22, 17.32, 17.17, 17.14.

ESI (pos. ion): $\mathrm{m} / \mathrm{z}$ calculated for $\mathrm{C}_{39} \mathrm{H}_{60} \mathrm{O}_{15} \mathrm{Na}(\mathrm{M}+\mathrm{Na}):$ 791.38, Found: 791.55

HRMS (TOF MS ES+) m/z calculated for $\mathrm{C}_{39} \mathrm{H}_{60} \mathrm{O}_{15} \mathrm{Na}(\mathrm{M}+\mathrm{Na}):$ : 791.3830, Found: 791.3815

$[\alpha]_{\lambda}^{23}\left(\mathrm{c}=0.29, \mathrm{CH}_{2} \mathrm{Cl}_{2}\right)=-29.08$ 


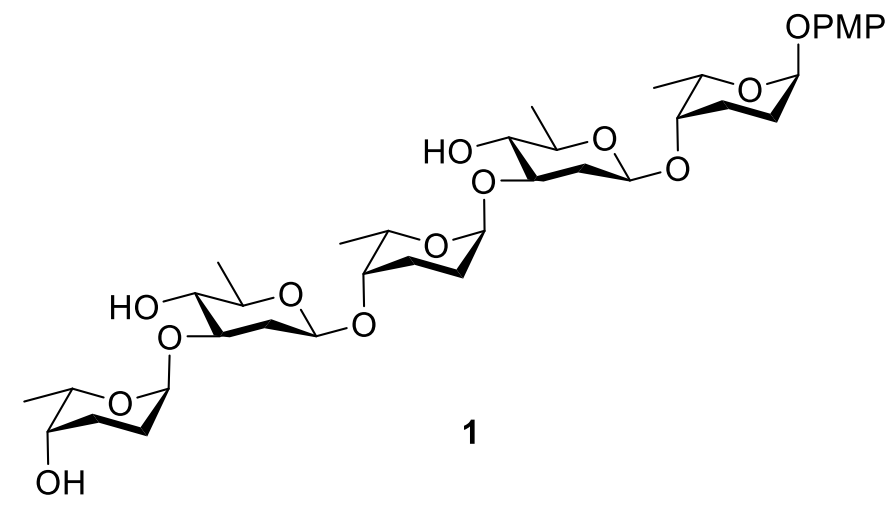

p-Methoxyphenyl 2,3-dideoxy-4-0-(2-deoxy-3-0-(2,3-dideoxy-4-0-(2-deoxy-3-0-(2,3-dideoxy$\alpha$-L-fucopyranosyl)- $\beta$-D-rhamnopyranosyl)- $\alpha$-L-fucopyranosyl)- $\beta$-D-rhamnpyranosyl)- $\alpha$-L-

fucopyranoside Compound $24(1.9 \mathrm{mg}, 0.002 \mathrm{mmol})$ was dissolved in $2 \mathrm{~mL}$ dry methanol. Potassium carbonate (roughly $0.5 \mathrm{mg}, 0.0005 \mathrm{mmol}$ ) was added and the reaction was stirred at room temperature. When the starting material had been consumed as determined by thin layer chromatography, the reaction was filtered through a small pad of silica with ethyl acetate, and the solvent removed under reduced pressure. The concentrate was purified by flash chromatography (60\% to $80 \%$ ethyl acetate: hexanes) to afford compound $\mathbf{1}$ as a clear oil. Residual grease was removed by dissolving $\mathbf{1}$ in methanol and washing with hexanes (1.7 $\mathrm{mg}$, quant).

${ }^{1} \mathrm{H}$ NMR $(500 \mathrm{MHz}$, Chloroform-d) $\delta 7.02-6.98(\mathrm{~m}, 2 \mathrm{H}), 6.84-6.79(\mathrm{~m}, 2 \mathrm{H}), 5.46(\mathrm{~s}, 1 \mathrm{H}), 4.95(\mathrm{~s}, 2 \mathrm{H})$, $4.48(\mathrm{~d}, J=9.8 \mathrm{~Hz}, 2 \mathrm{H}), 4.37(\mathrm{~s}, 1 \mathrm{H}), 4.17(\mathrm{~s}, 1 \mathrm{H}), 4.16-4.12(\mathrm{~m}, 1 \mathrm{H}), 4.09(\mathrm{q}, J=6.4 \mathrm{~Hz}, 1 \mathrm{H}), 4.01(\mathrm{q}, J=$ $6.4 \mathrm{~Hz}, 1 \mathrm{H}), 3.77(\mathrm{~s}, 3 \mathrm{H}), 3.64(\mathrm{~s}, 1 \mathrm{H}), 3.55(\mathrm{~s}, 2 \mathrm{H}), 3.52-3.44(\mathrm{~m}, 2 \mathrm{H}), 3.35(\mathrm{~s}, 1 \mathrm{H}), 3.28-3.21(\mathrm{~m}, 2 \mathrm{H})$, $3.12-3.06(\mathrm{~m}, 2 \mathrm{H}), 2.30-1.92(\mathrm{~m}, 12 \mathrm{H}), 1.80-1.61(\mathrm{~m}, 4 \mathrm{H}), 1.37-1.33(\mathrm{~m}, 6 \mathrm{H}), 1.22(\mathrm{~d}, J=6.6 \mathrm{~Hz}$, $3 \mathrm{H}), 1.19(\mathrm{~d}, J=6.6 \mathrm{~Hz}, 3 \mathrm{H}), 1.12(\mathrm{~d}, J=6.5 \mathrm{~Hz}, 3 \mathrm{H})$.

${ }^{13} \mathrm{C}$ NMR $\left(126 \mathrm{MHz}, \mathrm{CDCl}_{3}\right) \delta$ 154.55, 151.52, 117.70, 114.68, 101.69, 101.47, 97.77, 97.38, 96.68, 81.13, $80.75,76.18,76.04,75.87,75.79,71.95(2 \mathrm{C}), 67.70,67.68,67.35,66.97,55.83,37.36,37.20,25.69$, $25.26,24.90,24.66,24.61,24.25,18.28,18.23,17.32,17.18,17.15$.

LRMS (ESI, pos. ion): $\mathrm{m} / \mathrm{z}$ calculated for $\mathrm{C}_{37} \mathrm{H}_{58} \mathrm{O}_{14} \mathrm{Na}(\mathrm{M}+\mathrm{Na}):$ 749.38, Found: 749.55

HRMS (TOF MS ES+): $\mathrm{m} / \mathrm{z}$ calculated for $\mathrm{C}_{37} \mathrm{H}_{58} \mathrm{O}_{14} \mathrm{Na}(\mathrm{M}+\mathrm{Na}):$ 749.3724, Found: 749.3724

$[\alpha]_{\lambda}^{23}(\mathrm{c}=0.09, \mathrm{MeOH})=5.92$ 


\section{References:}

(1) Tanaka, H.; Yoshizawa, A.; Takahashi, T. Direct and Stereoselective Synthesis of $\beta$-Linked 2,6Deoxyoligosaccharides. Angew. Chemie - Int. Ed. 2007, 46, 2505-2507.

(2) Srinivasarao, M.; Park, T.; Chen, Y.; Fuchs, P. L. Noteworthy Observations Accompanying Synthesis of the Apoptolidin Disaccharide. Chem. Commun. 2011, 47, 5858-5860.

(3) Sobti, A.; Sulikowski, G. A. Mitsunobu Reactions of Glycals with Phenoxide Nucleophiles Are SN2'Selective. Tetrahedron Lett. 1994, 35, 3661-3664.

(4) Sobti, A.; Kim, K.; Sulikowski, G. A. Application of Glycosyltetrazoles in Oligosaccharide Synthesis: Assembly of the C3 Trisaccharide Component of the Antibiotic PI-080. J. Org. Chem. 1996, 61, 67.

(5) Banaszek, A. Synthesis of Isomeric Benzyl 6-Deoxy- $\alpha$-L-Talo- and $\alpha$-L-Gulopyranosides. J. Carbohydr. Chem. 1994, 13, 285-291.

(6) El Khadem, H.; Cermak, R. C. Rhodinose Derivatives Suitable for the Synthesis of Anthracycline Analogs. Carbohydr. Res. 1979, 75, 335-339.

(7) Sobti, A.; Sulikowski, G. A. Synthesis of 4-O-Acetyl-I-Rhodinopyranose via a Tandem Sharpless Asymmetric Dihydroxylation/Lipase-Catalyzed Transesterification. Tetrahedron Lett. 1995, 36, 4193-4196.

(8) Di Bussolo, V.; Favero, L.; Romano, M. R.; Pineschi, M.; Crotti, P. Synthesis of Diastereoisomeric 6Deoxy-d-Allal- and 6-Deoxy-d-Galactal-Derived Allyl Epoxides and Examination of the Regio- and Stereoselectivity in Nucleophilic Addition Reactions. Comparison with the Corresponding 6-OFunctionalized Allyl Epoxides. Tetrahedron 2008, 64, 8188-8201.

(9) Tanaka, H.; Yamaguchi, S.; Yoshizawa, A.; Takagi, M.; Shinya, K.; Takahashi, T. Combinatorial Synthesis of Deoxyhexasaccharides Related to the Landomycin a Sugar Moiety, Based on an Orthogonal Deprotection Strategy. Chem. - An Asian J. 2010, 5, 1407-1424.

(10) Lloyd, D.; Bylsma, M.; Bright, D. K.; Chen, X.; Bennett, C. S. Mild Method for 2-Naphthylmethyl Ether Protecting Group Removal Using a Combination of 2,3-Dichloro-5,6-Dicyano-1,4Benzoquinone (DDQ) and $\beta$-Pinene. J. Org. Chem. 2017, acs.joc.7b00065. 


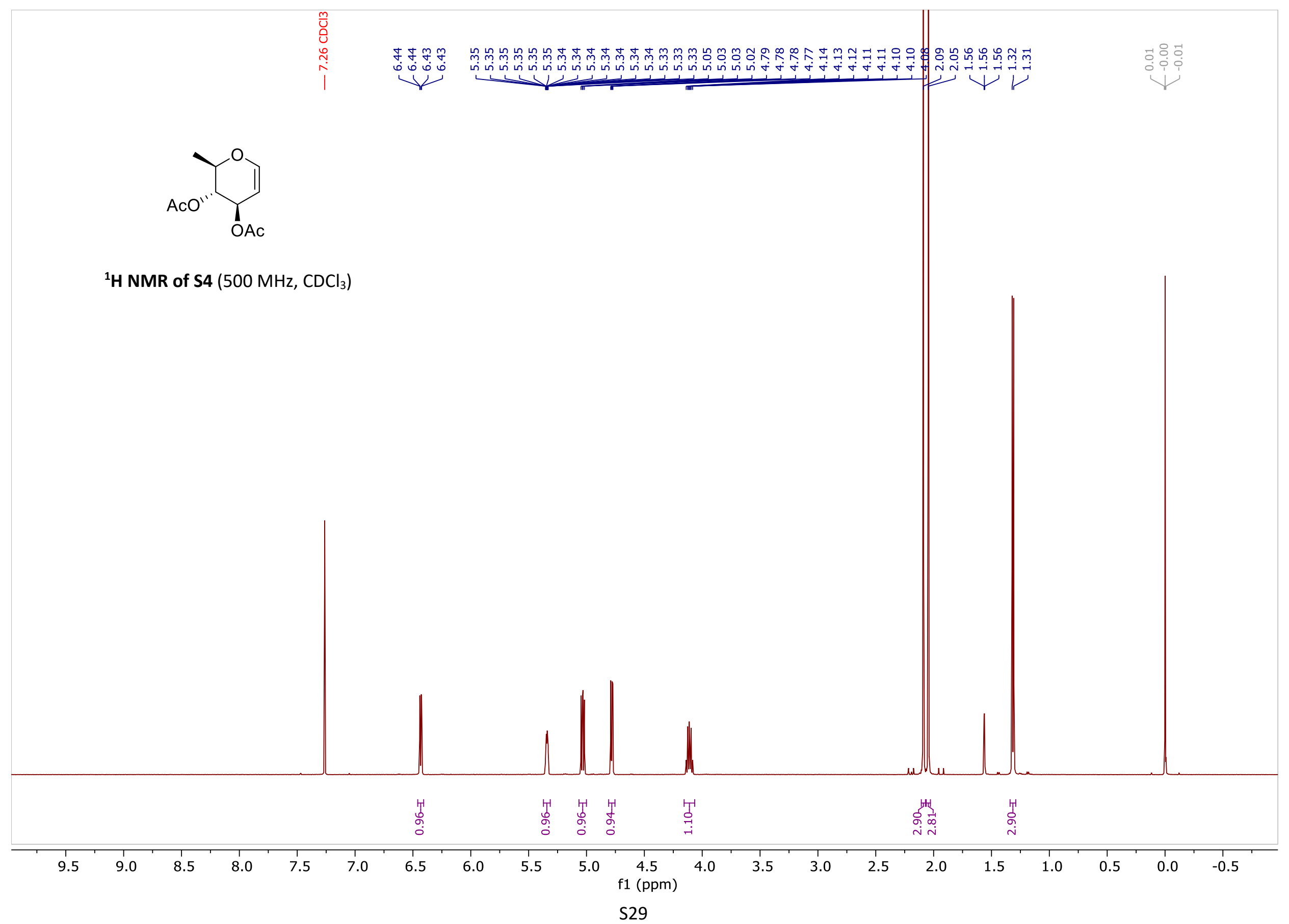




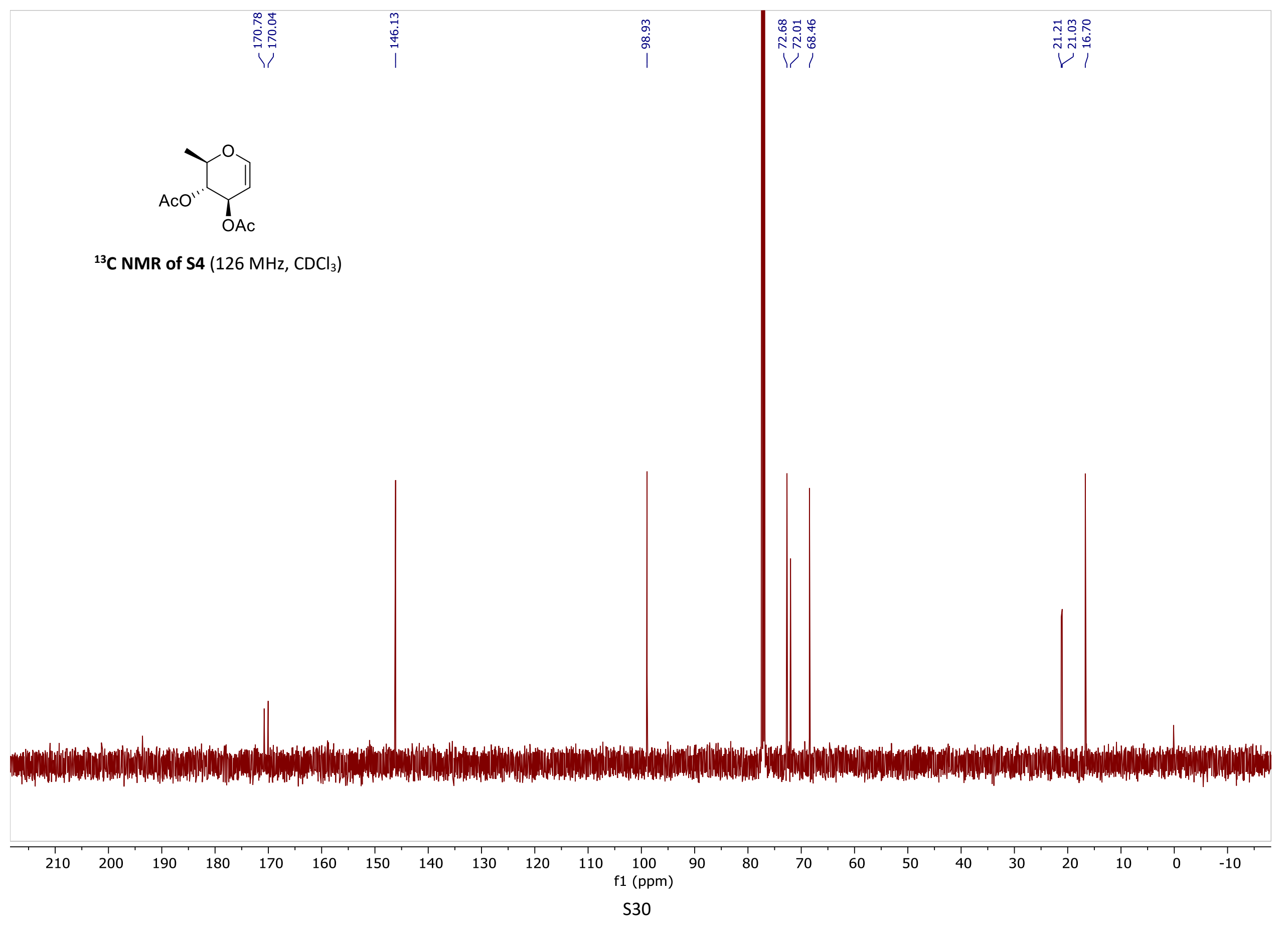


<smiles>C[C@@H]1OC=C[C@H](O)[C@H]1O</smiles>

${ }^{1} \mathrm{H}$ NMR of $\mathrm{S} 5\left(500 \mathrm{MHz}, \mathrm{CDCl}_{3}\right)$

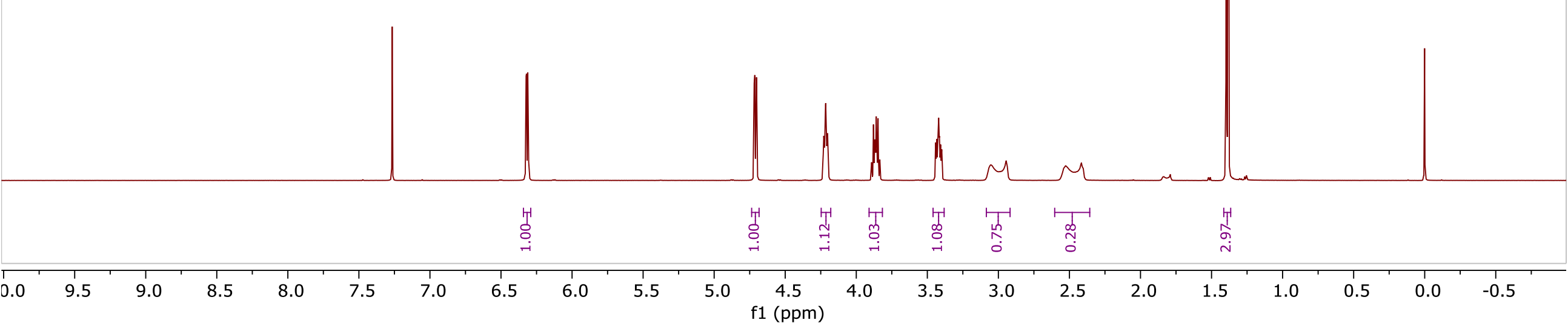


<smiles>C[C@@H]1OC=C[C@H](O)[C@H]1O</smiles>

${ }^{13} \mathrm{C}$ NMR of $\mathbf{S 5}\left(126 \mathrm{MHz}, \mathrm{CDCl}_{3}\right)$

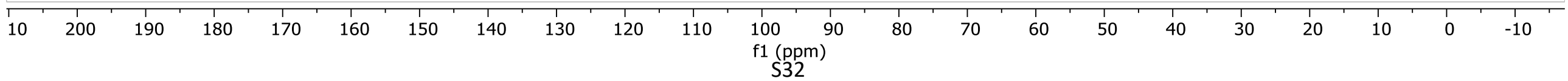


<smiles>C[C@@H]1OC(O[Pb])C=C[C@@H]1O</smiles>

${ }^{1} \mathbf{H}$ NMR of $7\left(500 \mathrm{MHz}, \mathrm{CDCl}_{3}\right)$
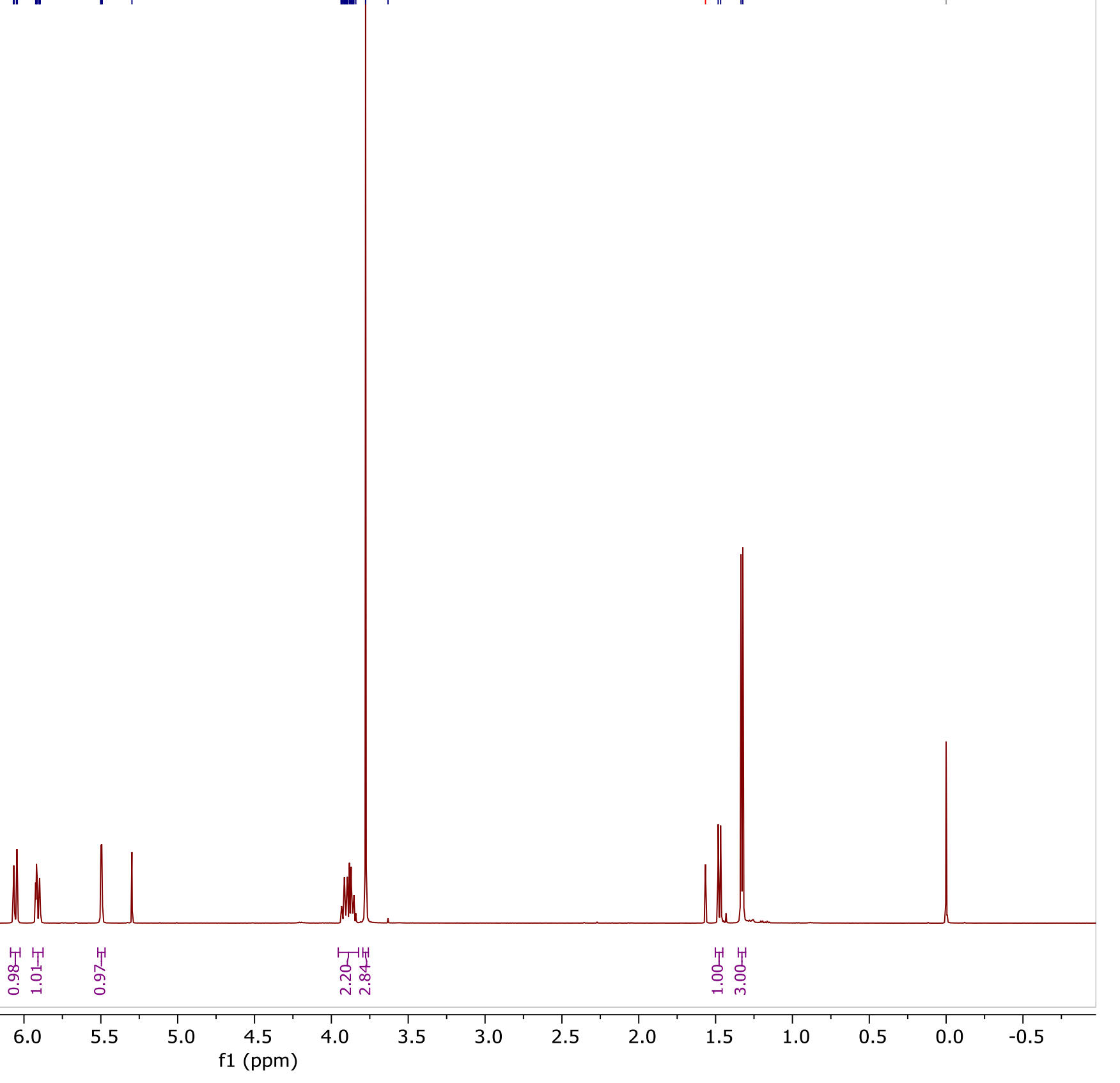


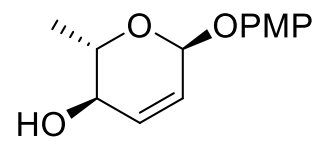

${ }^{13} \mathrm{C}$ NMR of $7\left(126 \mathrm{MHz}, \mathrm{CDCl}_{3}\right)$
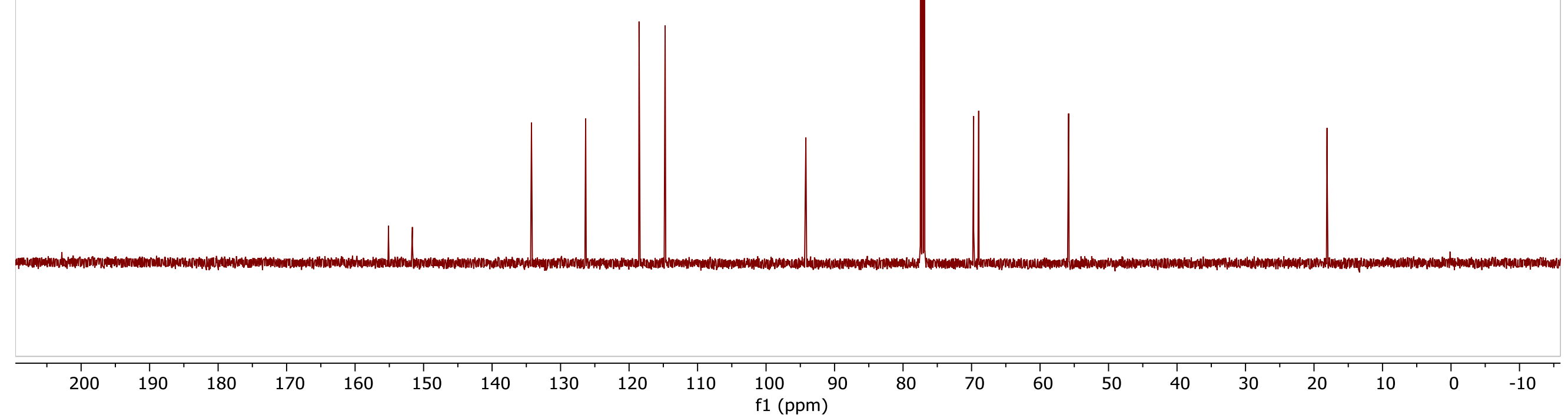


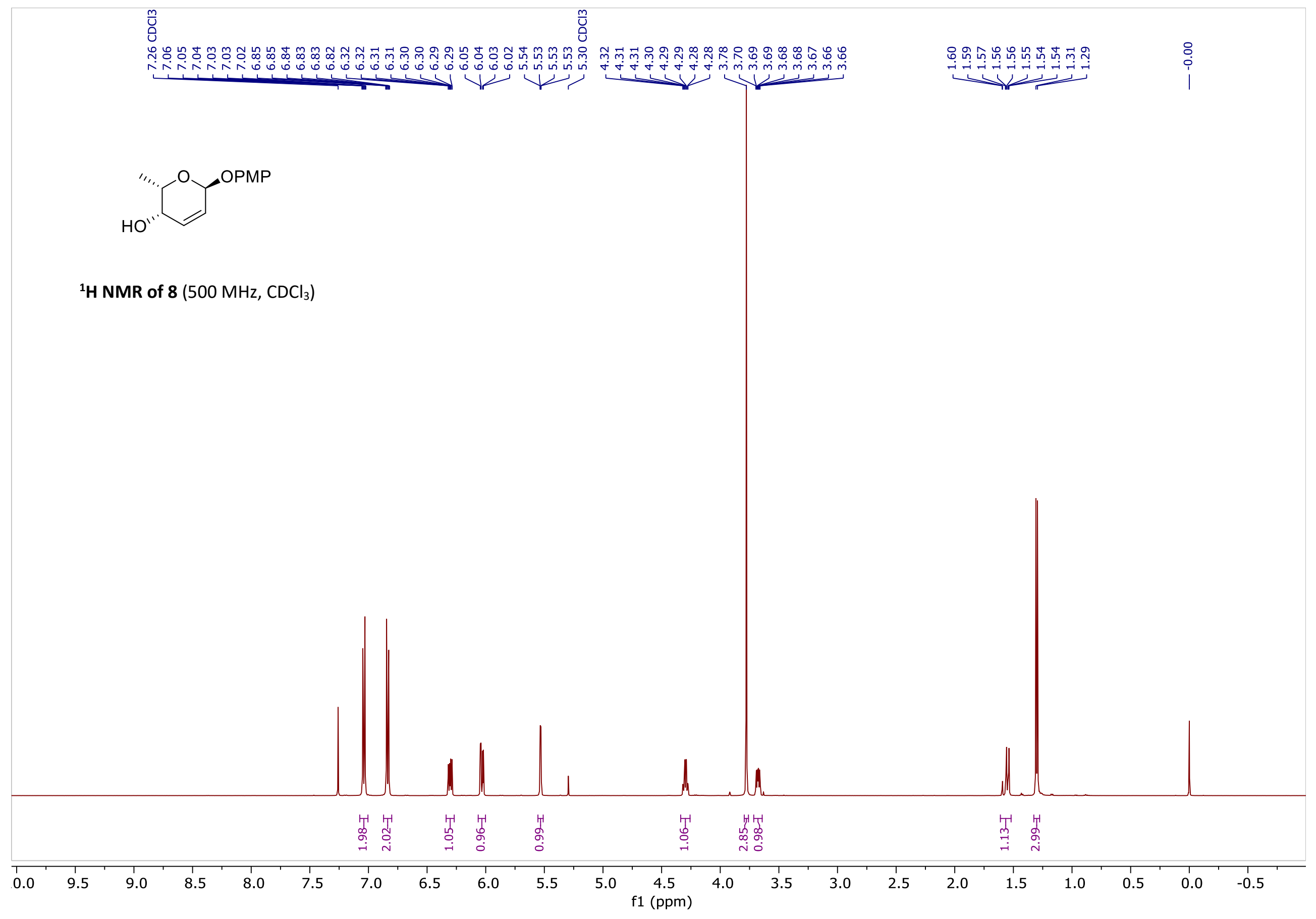




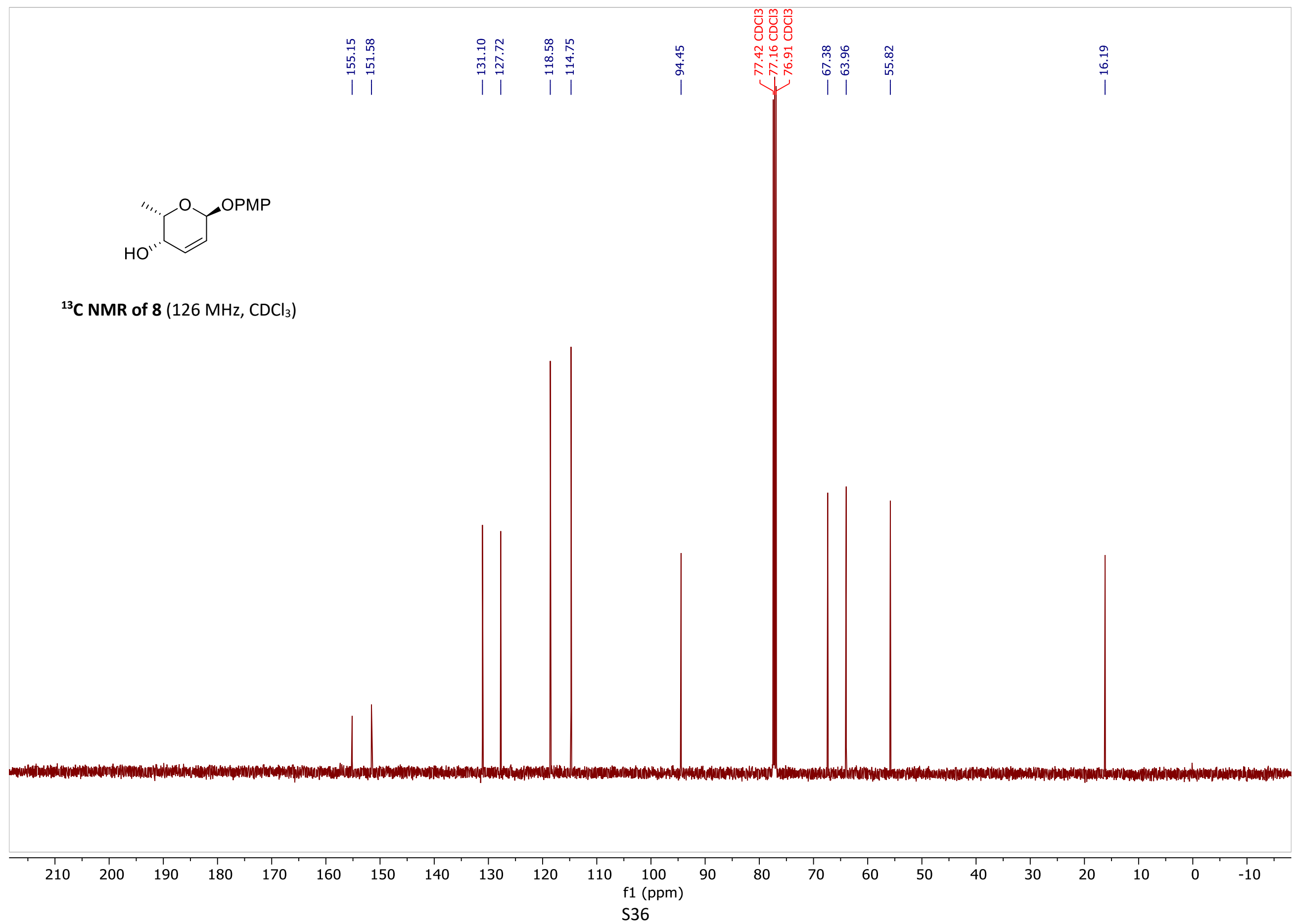


剀
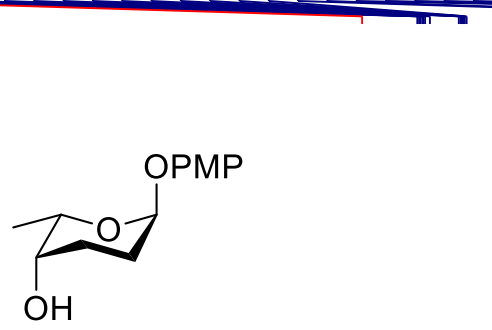

${ }^{1} \mathrm{H}$ NMR of $6\left(500 \mathrm{MHz}, \mathrm{CDCl}_{3}\right)$
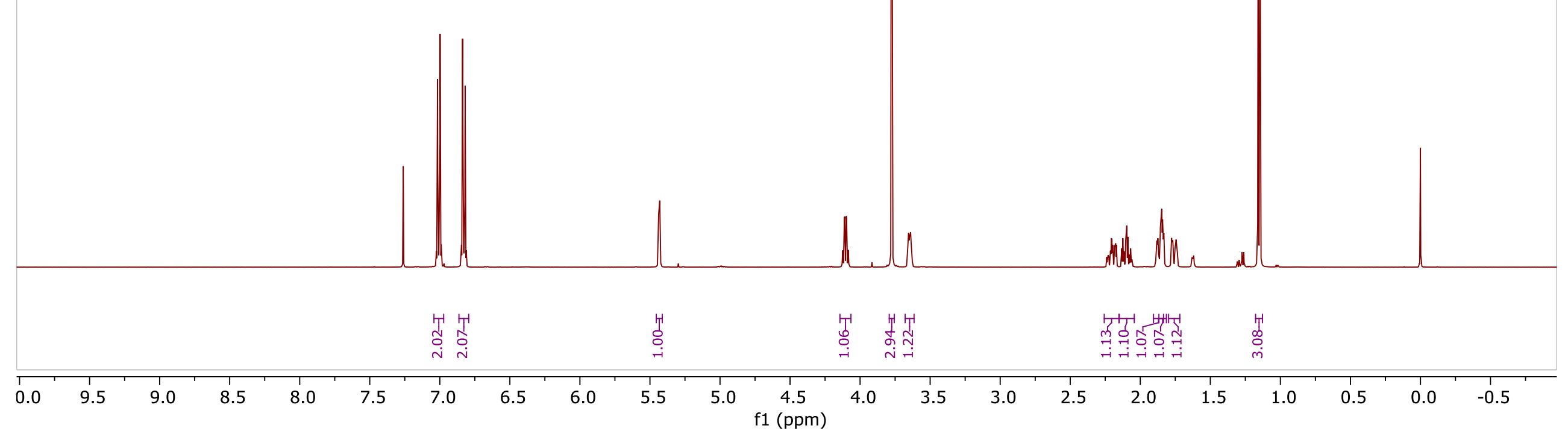

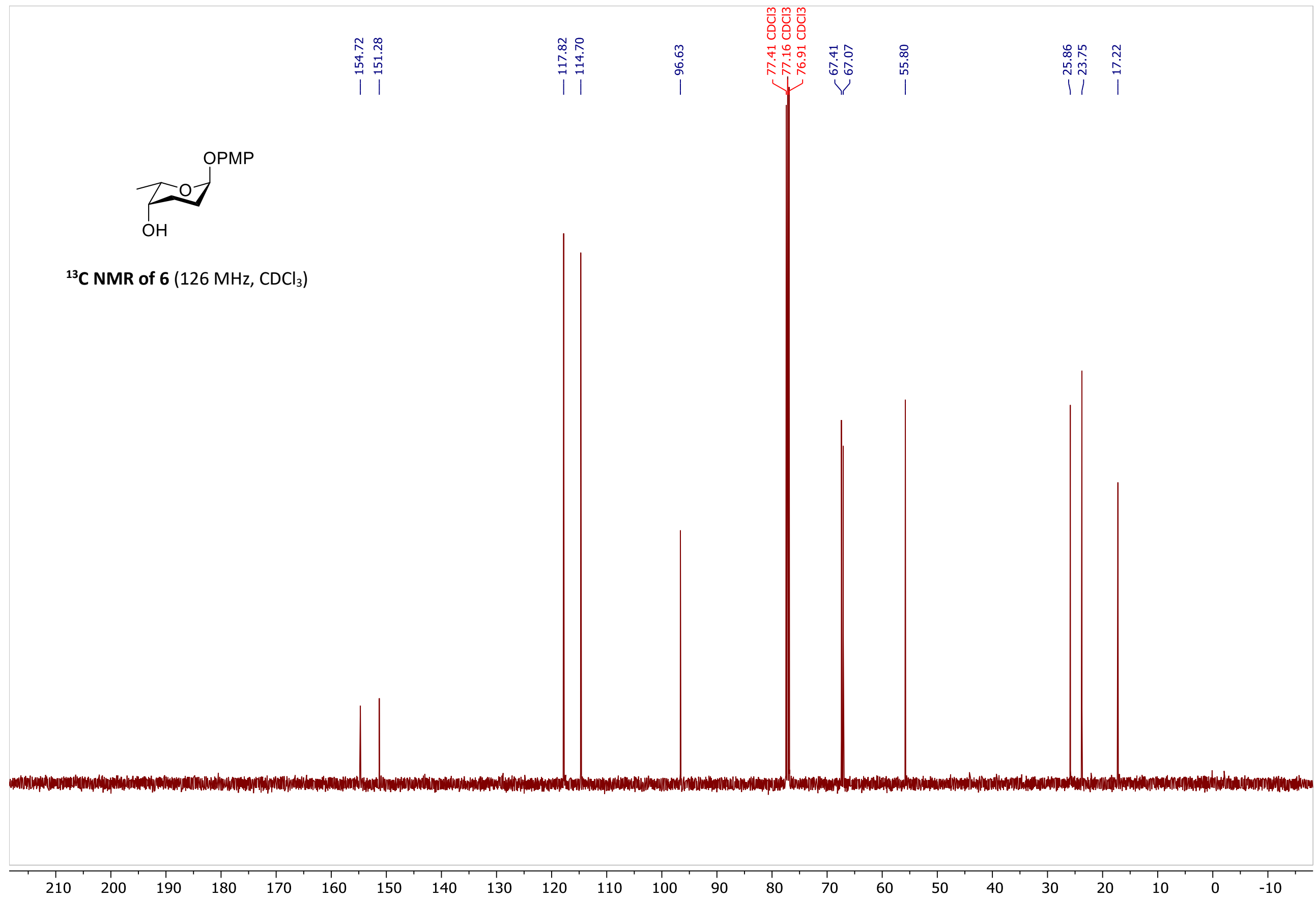

180
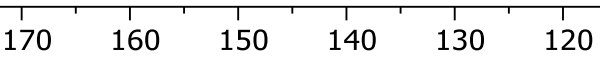

$\begin{array}{cc}110 & 100 \\ \mathrm{f} 1 & (\mathrm{ppm})\end{array}$ 


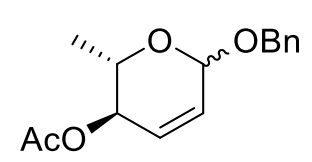

${ }^{1} \mathbf{H} \mathbf{N M R}$ of $\mathbf{S 7}\left(500 \mathrm{MHz}, \mathrm{CDCl}_{3}\right)$

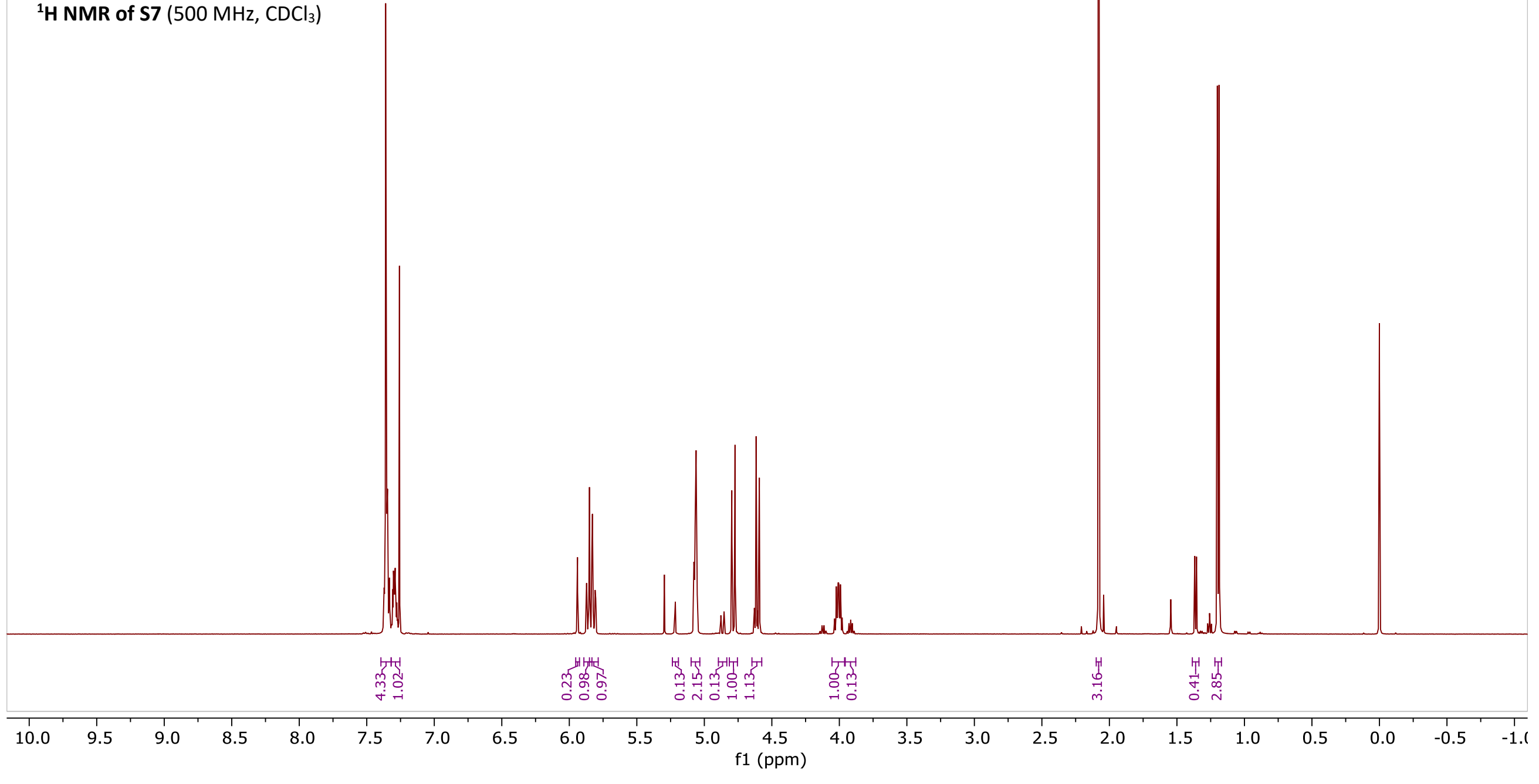




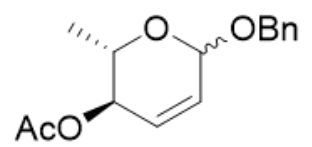

${ }^{13} \mathrm{C}$ NMR of $\mathrm{S} 7\left(126 \mathrm{MHz}, \mathrm{CDCl}_{3}\right)$

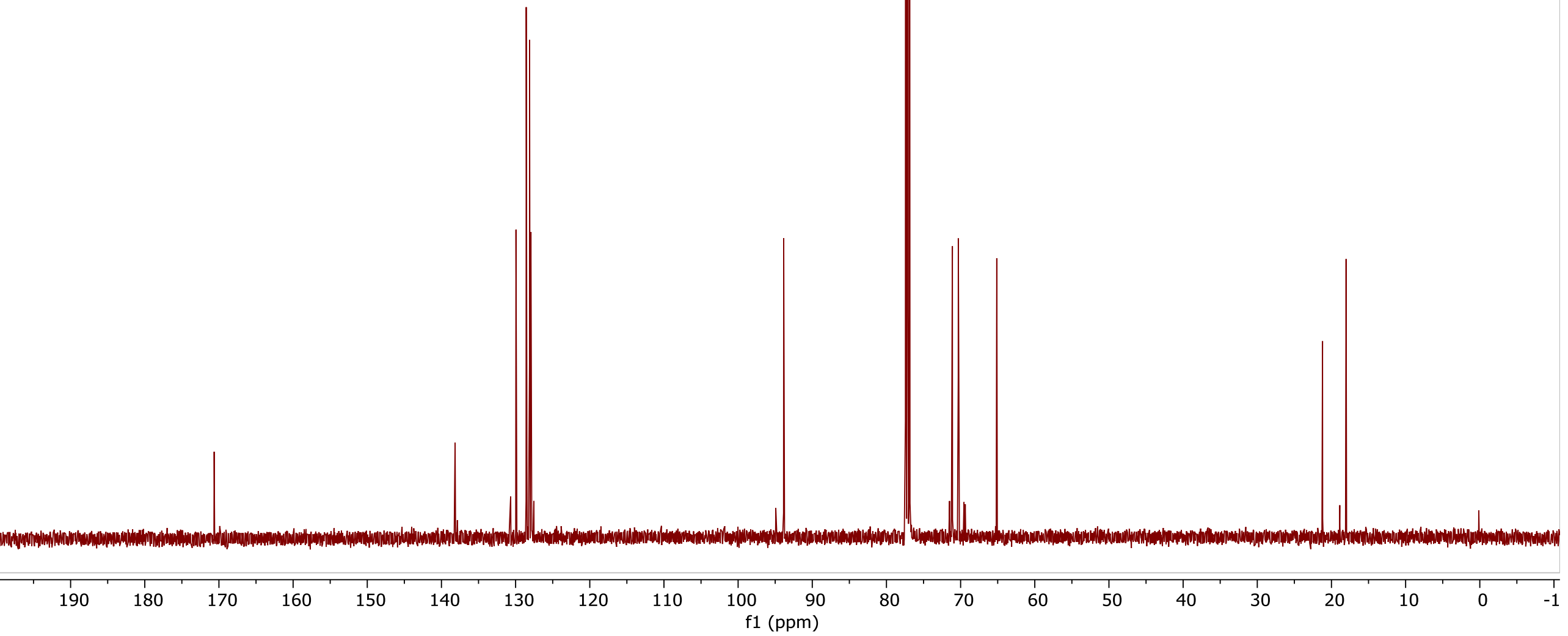


<smiles>[R16]C1C=CC(OC(C)=O)OC1C</smiles>

${ }^{1} \mathrm{H}$ NMR of $11\left(500 \mathrm{MHz}, \mathrm{CDCl}_{3}\right)$

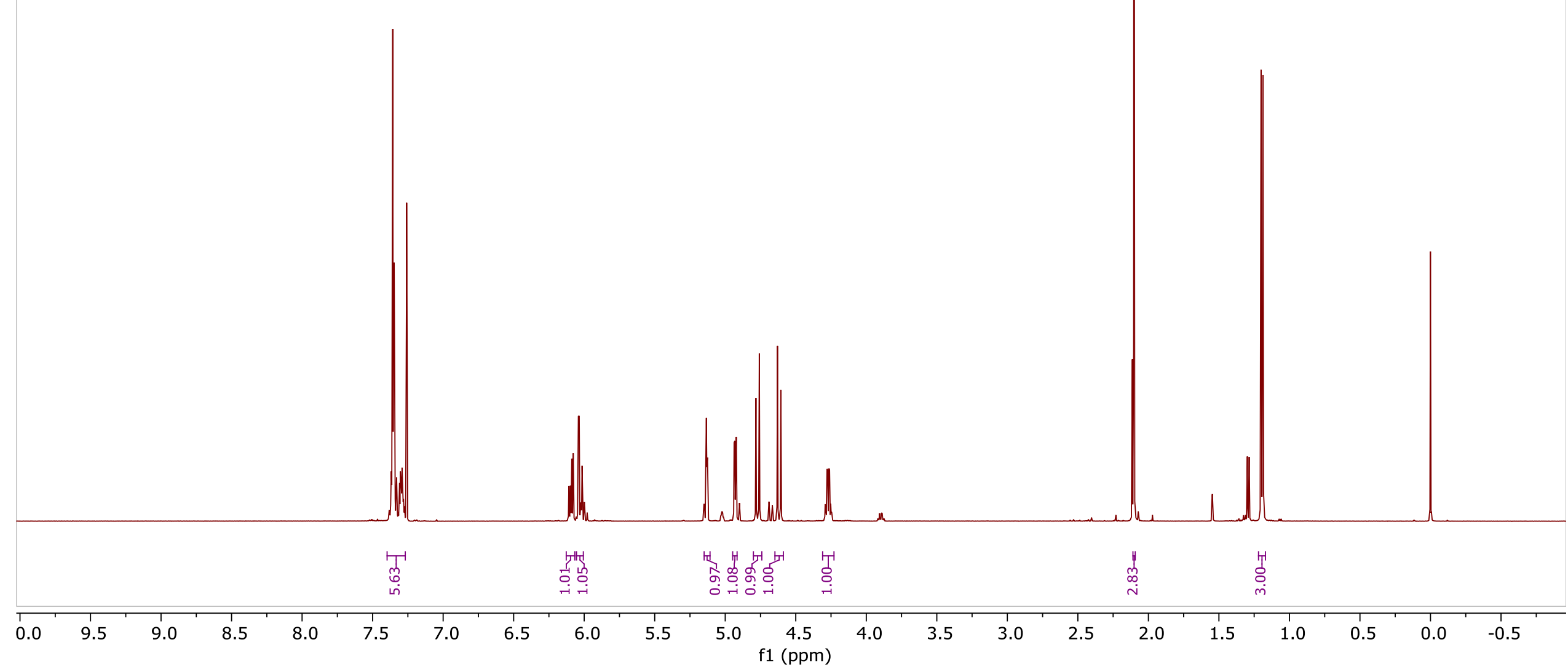




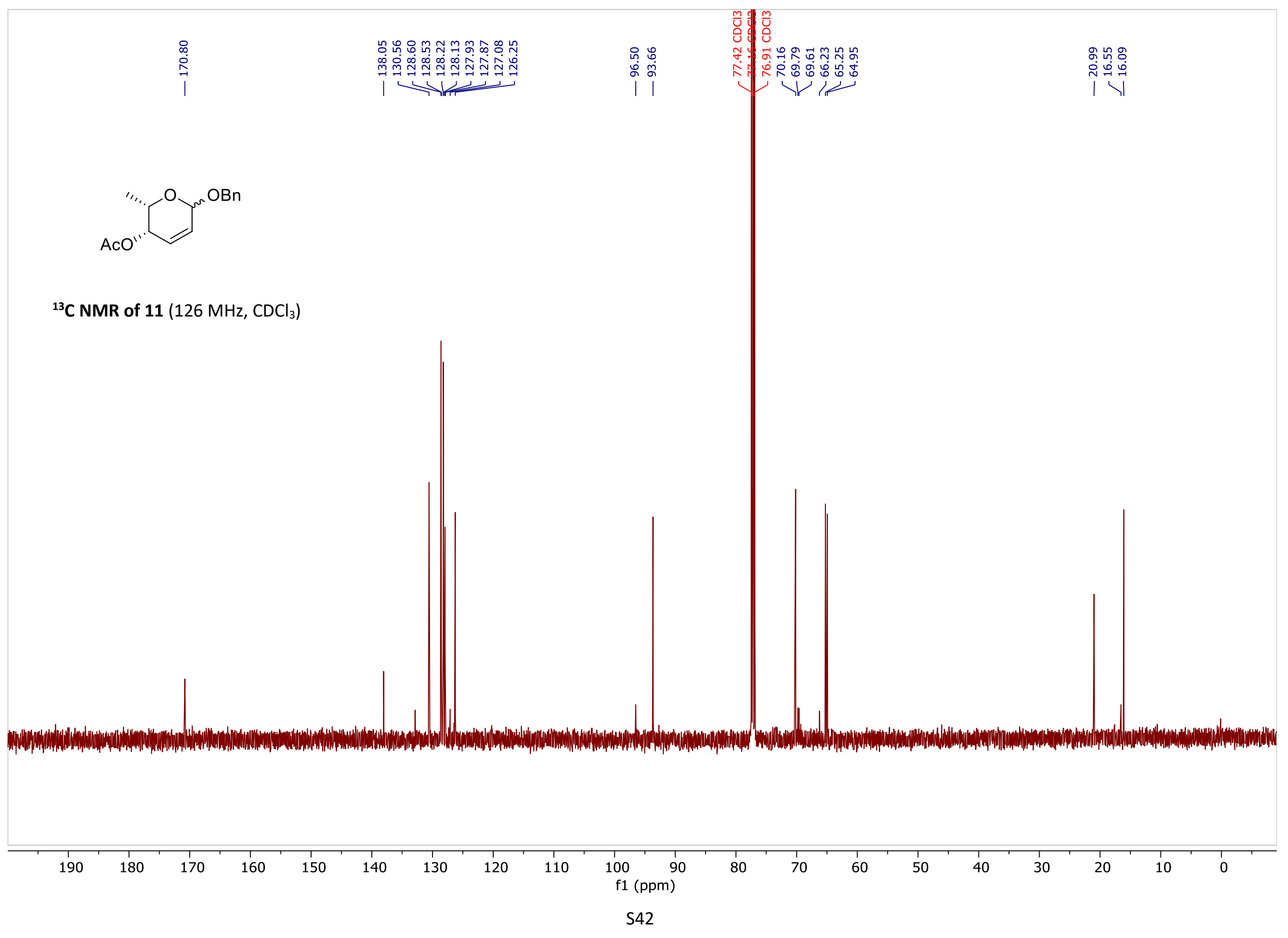




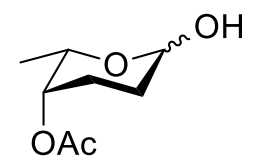

${ }^{1} \mathbf{H}$ NMR of $3\left(500 \mathrm{MHz}, \mathrm{CDCl}_{3}\right)$

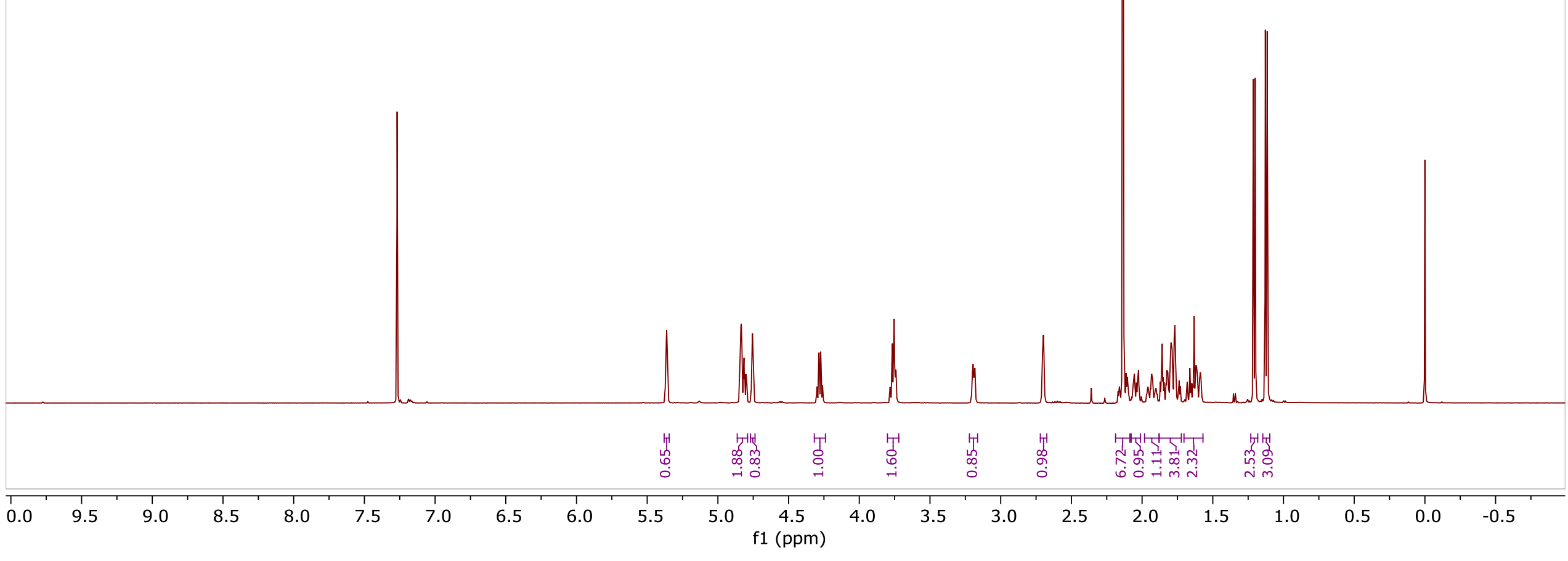




$$
4
$$




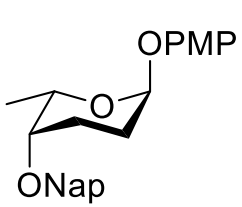

${ }^{1} \mathbf{H}$ NMR of $\mathbf{S 6}\left(500 \mathrm{MHz}, \mathrm{CDCl}_{3}\right)$

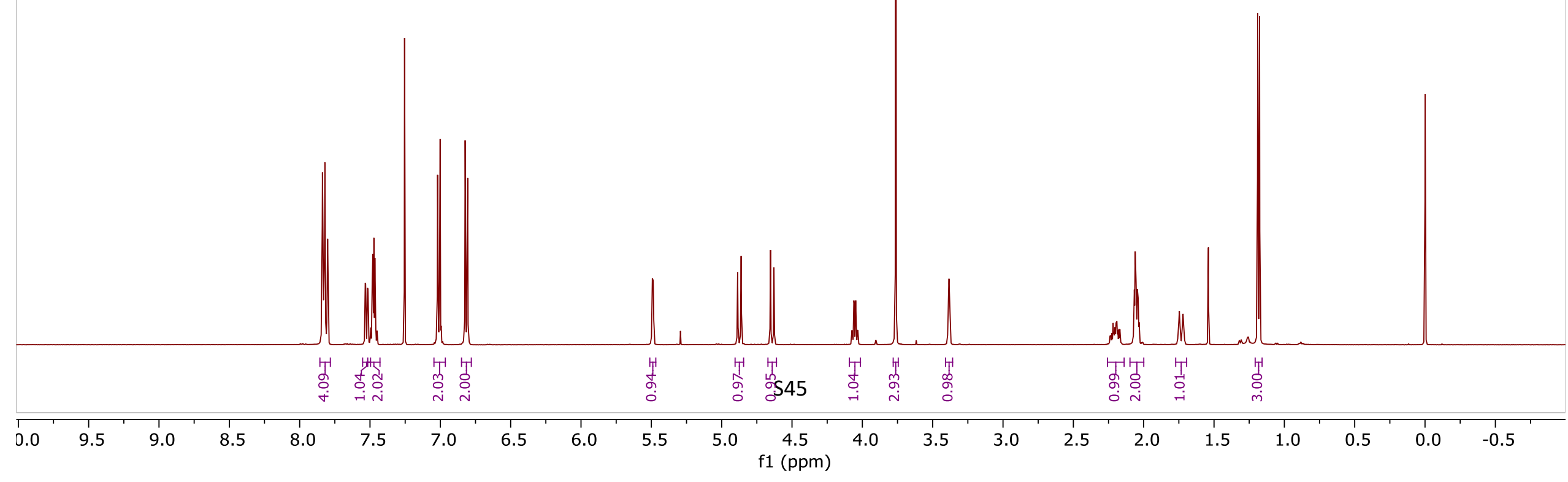




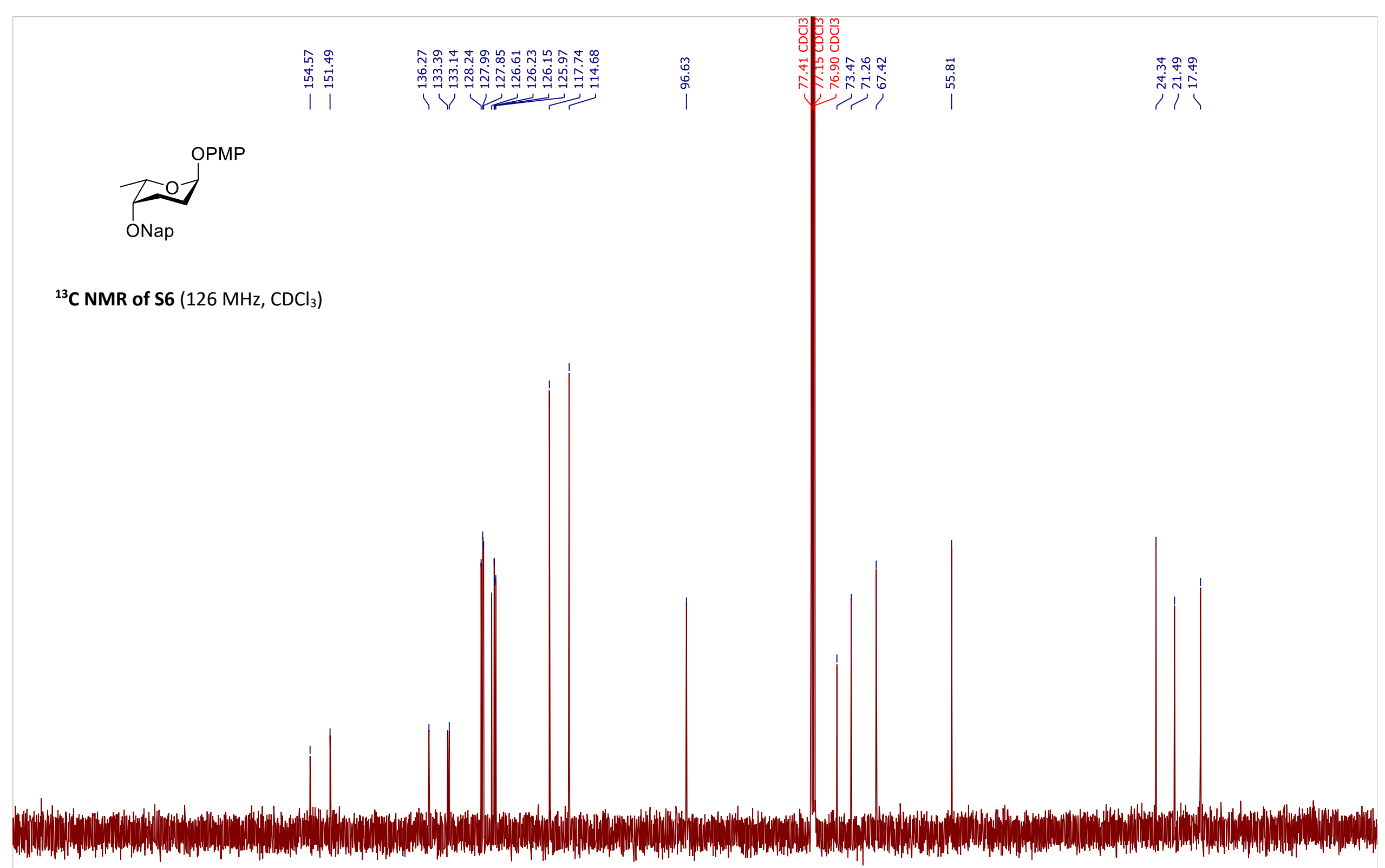

\begin{tabular}{|c|c|c|c|c|c|c|c|c|c|c|c|c|c|c|c|c|c|c|c|c|}
\hline 00 & 190 & 180 & 170 & 160 & 150 & 140 & 130 & 120 & 110 & $\begin{array}{r}100 \\
\text { f1 }\end{array}$ & $\begin{array}{l}90 \\
9)\end{array}$ & 80 & 70 & 60 & $\begin{array}{l}1 \\
50\end{array}$ & 40 & 30 & 20 & 10 & $\begin{array}{l}1 \\
0\end{array}$ \\
\hline
\end{tabular}


<smiles>CC1CC(O)CC(O)C1[N+](=O)[O-]</smiles>

${ }^{1} \mathrm{H}$ NMR of $19\left(500 \mathrm{MHz}, \mathrm{CDCl}_{3}\right)$

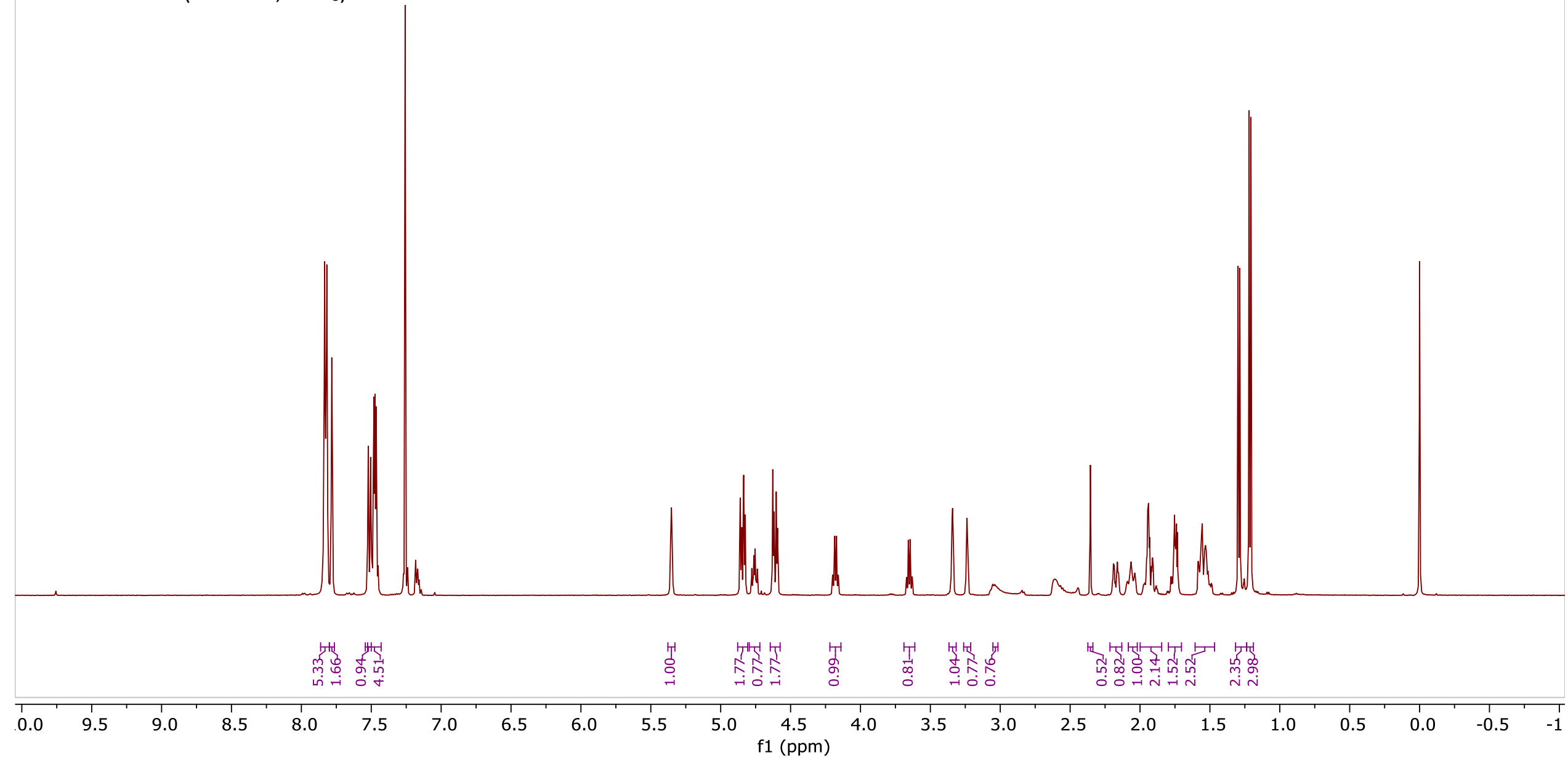




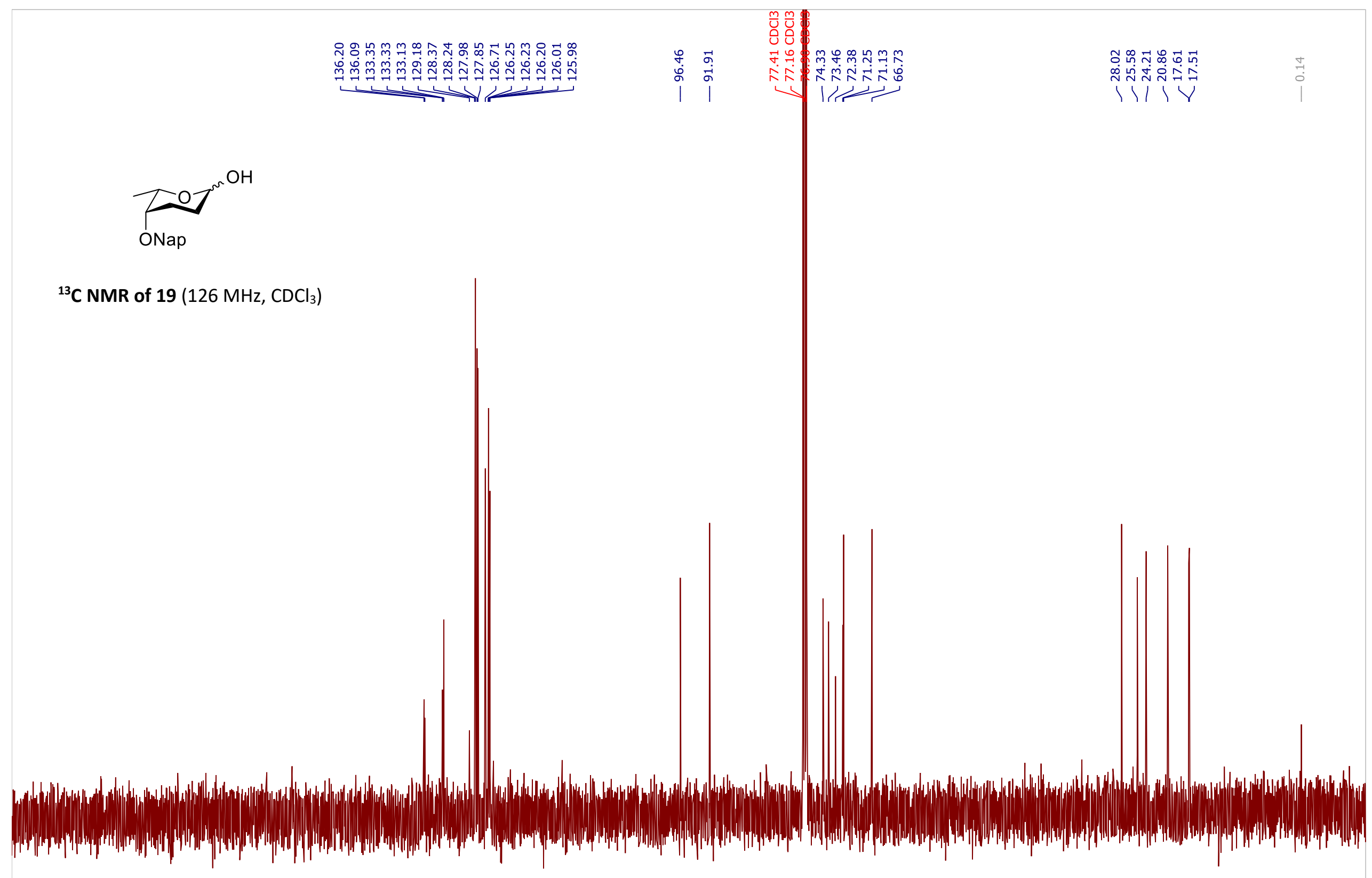

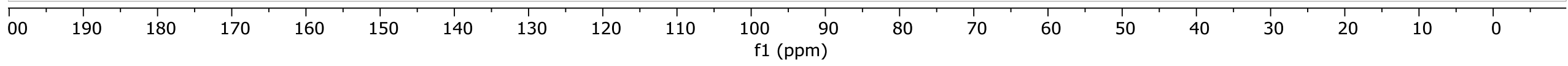




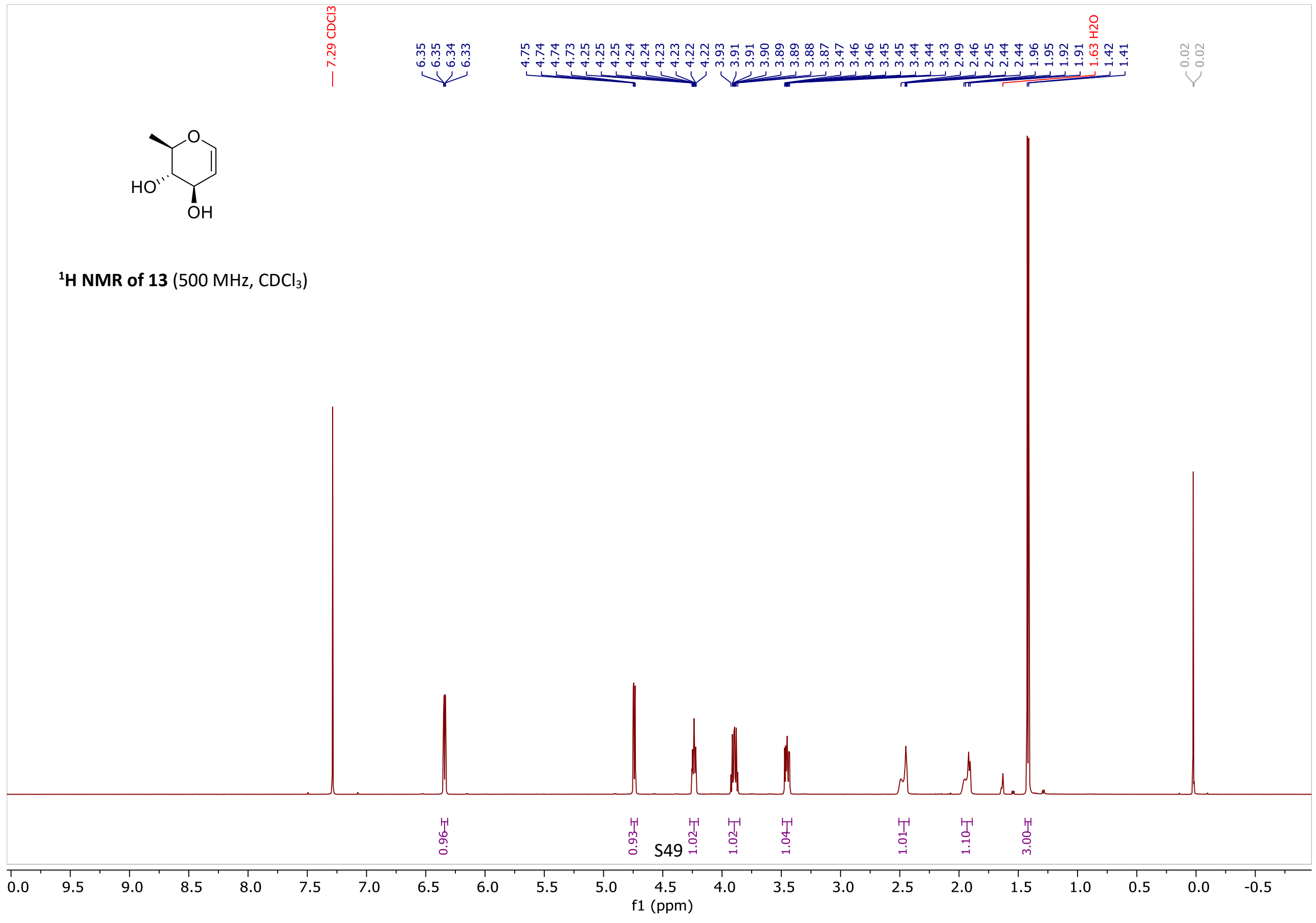


${ }^{13} \mathrm{C}$ NMR of $13\left(126 \mathrm{MHz}, \mathrm{CDCl}_{3}\right)$<smiles>C[C@@H]1OC=C[C@H](O)[C@H]1O</smiles> 
<smiles>C[C@@H]1OC=C[C@@H](O[N+](=O)[O-])[C@@H]1O</smiles>

${ }^{1} \mathrm{H}$ NMR of $14\left(500 \mathrm{MHz}, \mathrm{CDCl}_{3}\right)$

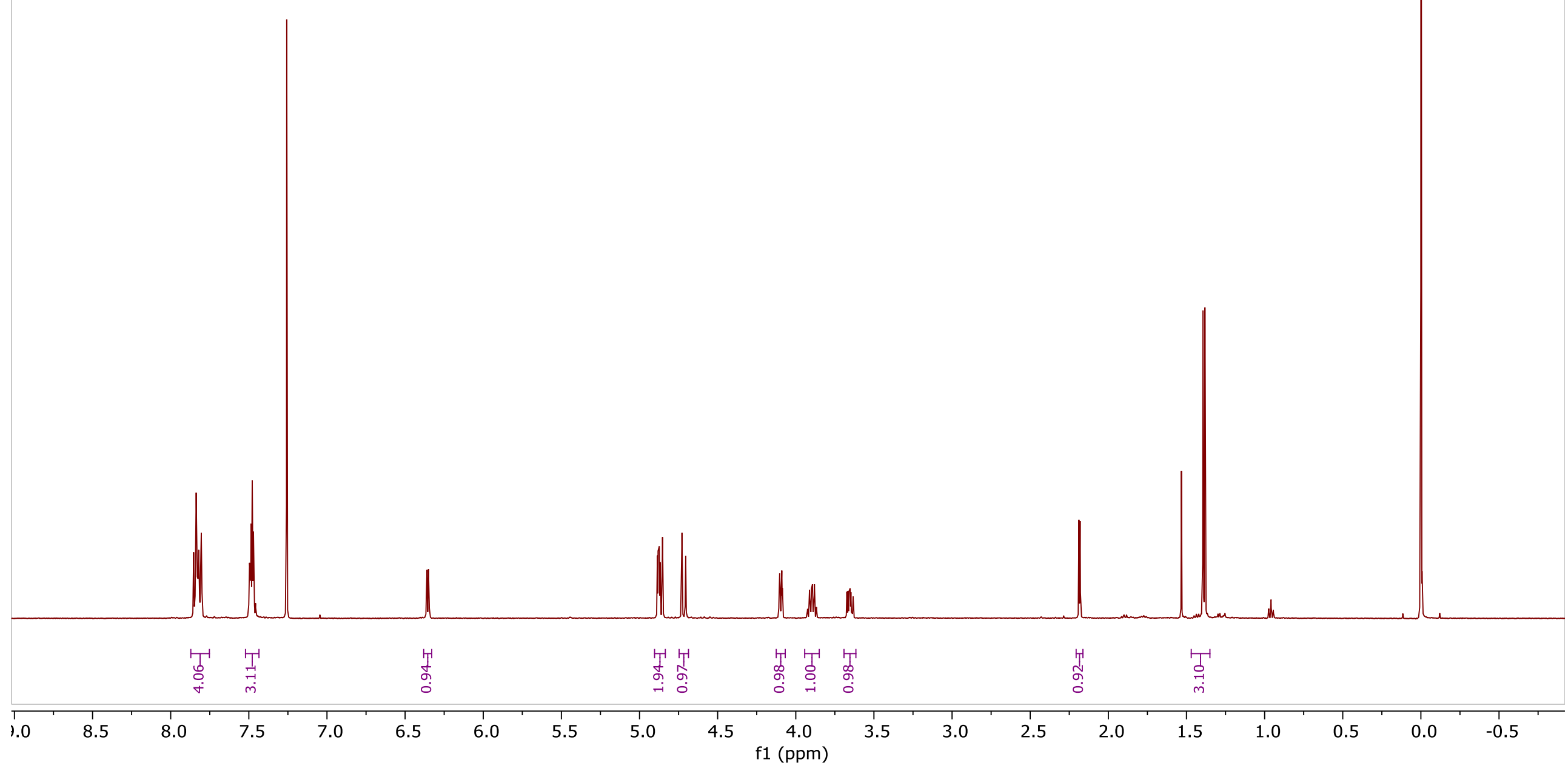




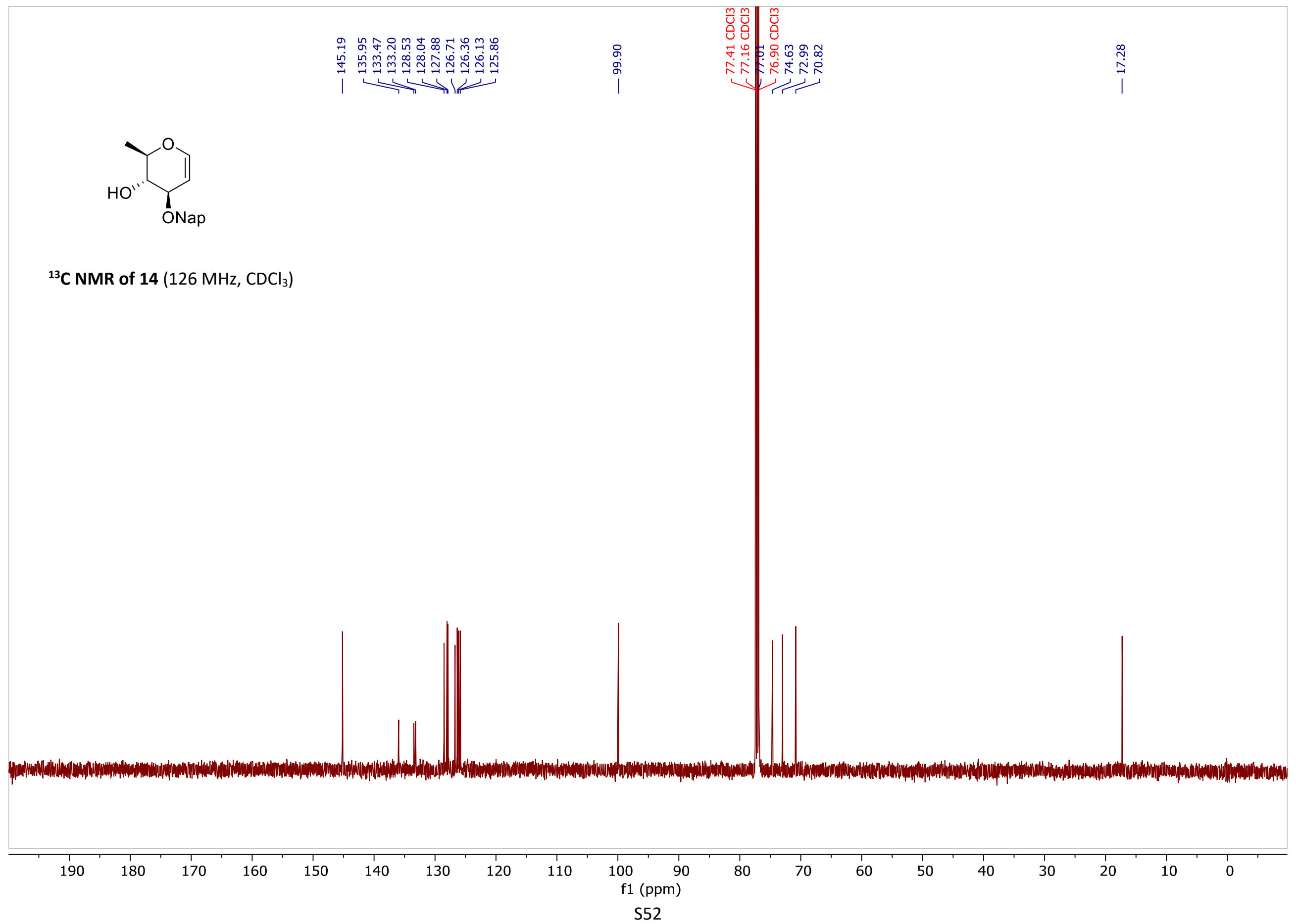


<smiles>C[C@H]1OC=C[C@@H](O[Nb])[C@@H]1OCc1ccccc1</smiles>

${ }^{1} \mathrm{H}$ NMR of $15\left(500 \mathrm{MHz}, \mathrm{CDCl}_{3}\right)$

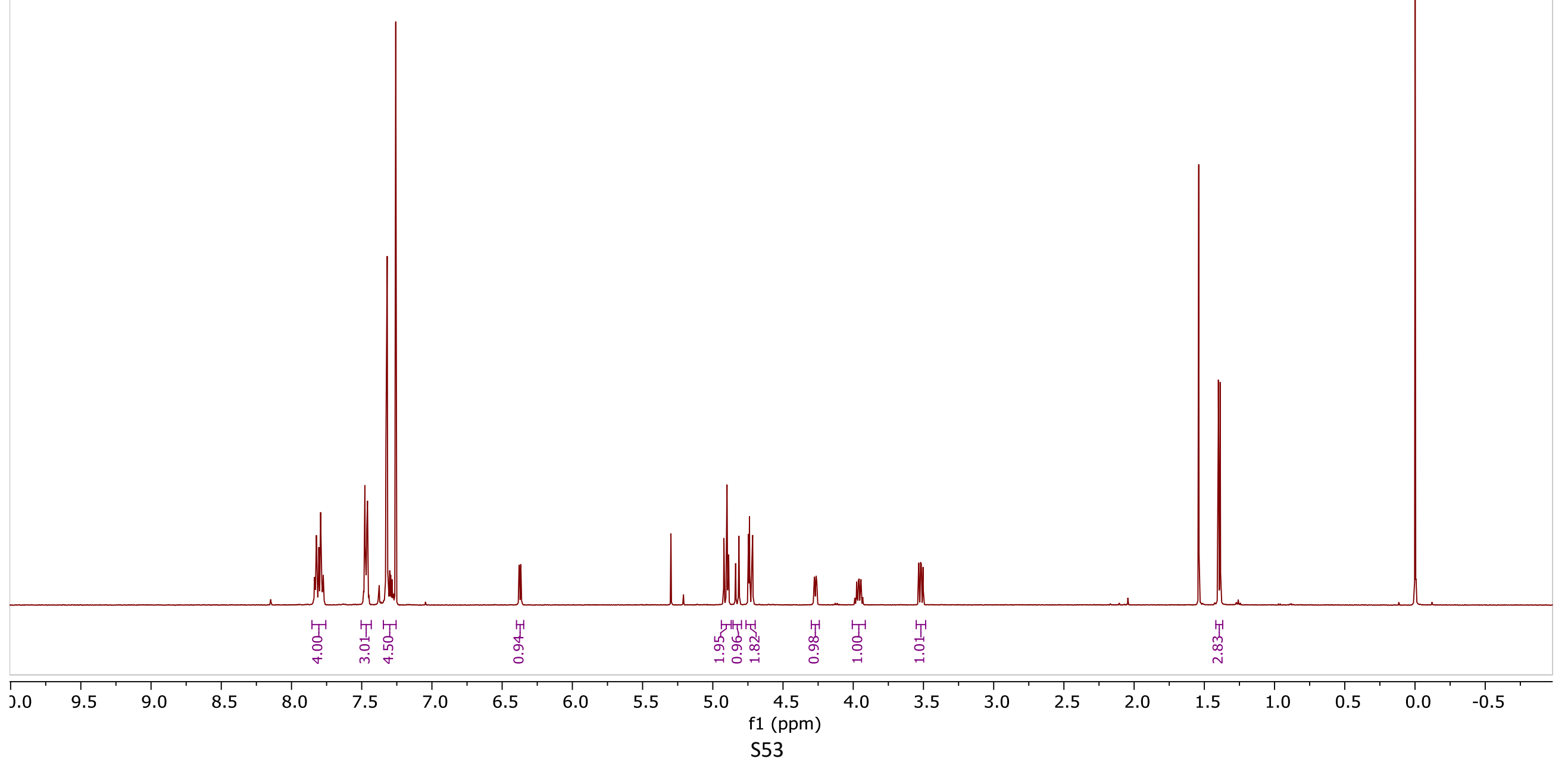




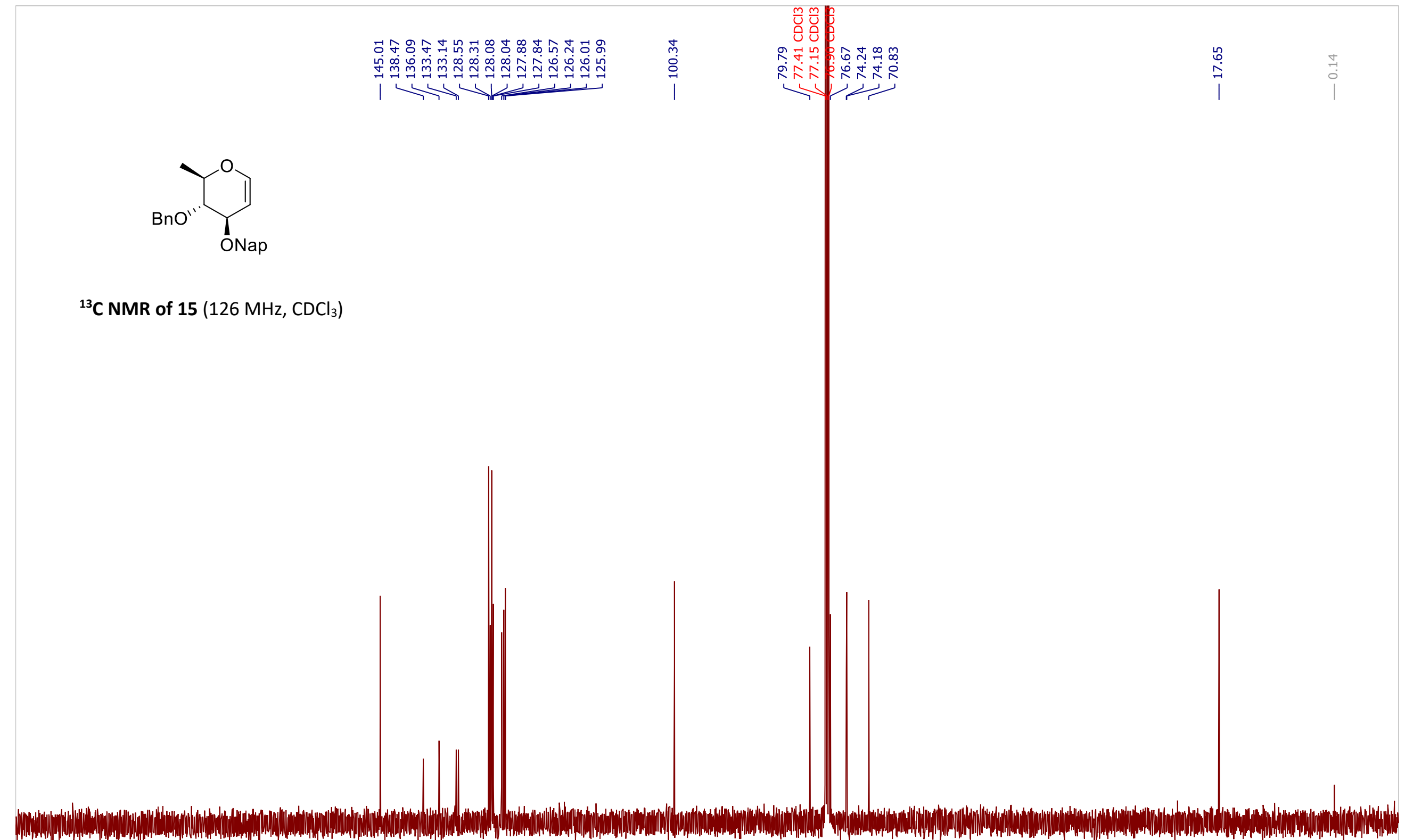

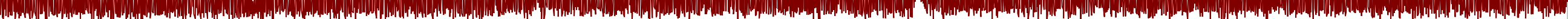

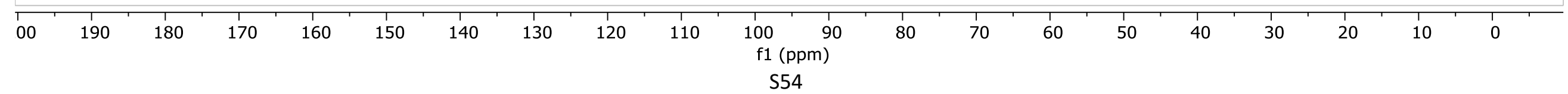




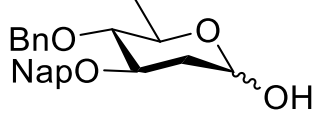

${ }^{1} \mathbf{H}$ NMR of $5\left(500 \mathrm{MHz}, \mathrm{CDCl}_{3}\right)$

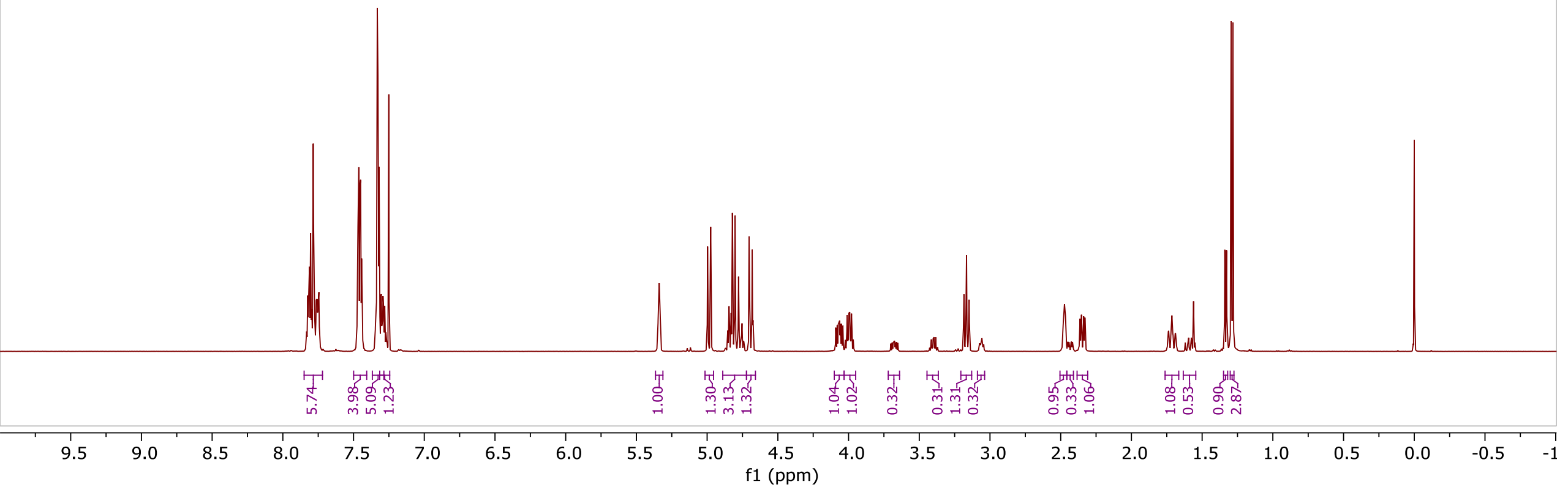




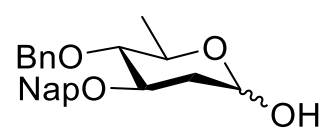

${ }^{13} \mathrm{C}$ NMR of $5\left(126 \mathrm{MHz}, \mathrm{CDCl}_{3}\right)$

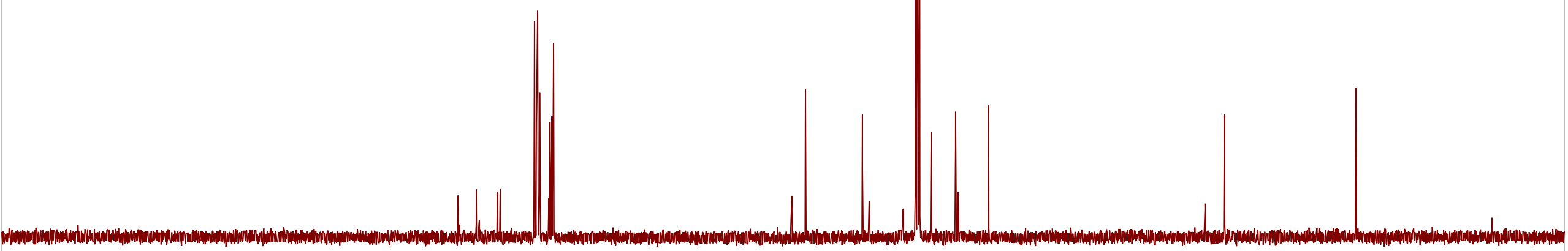




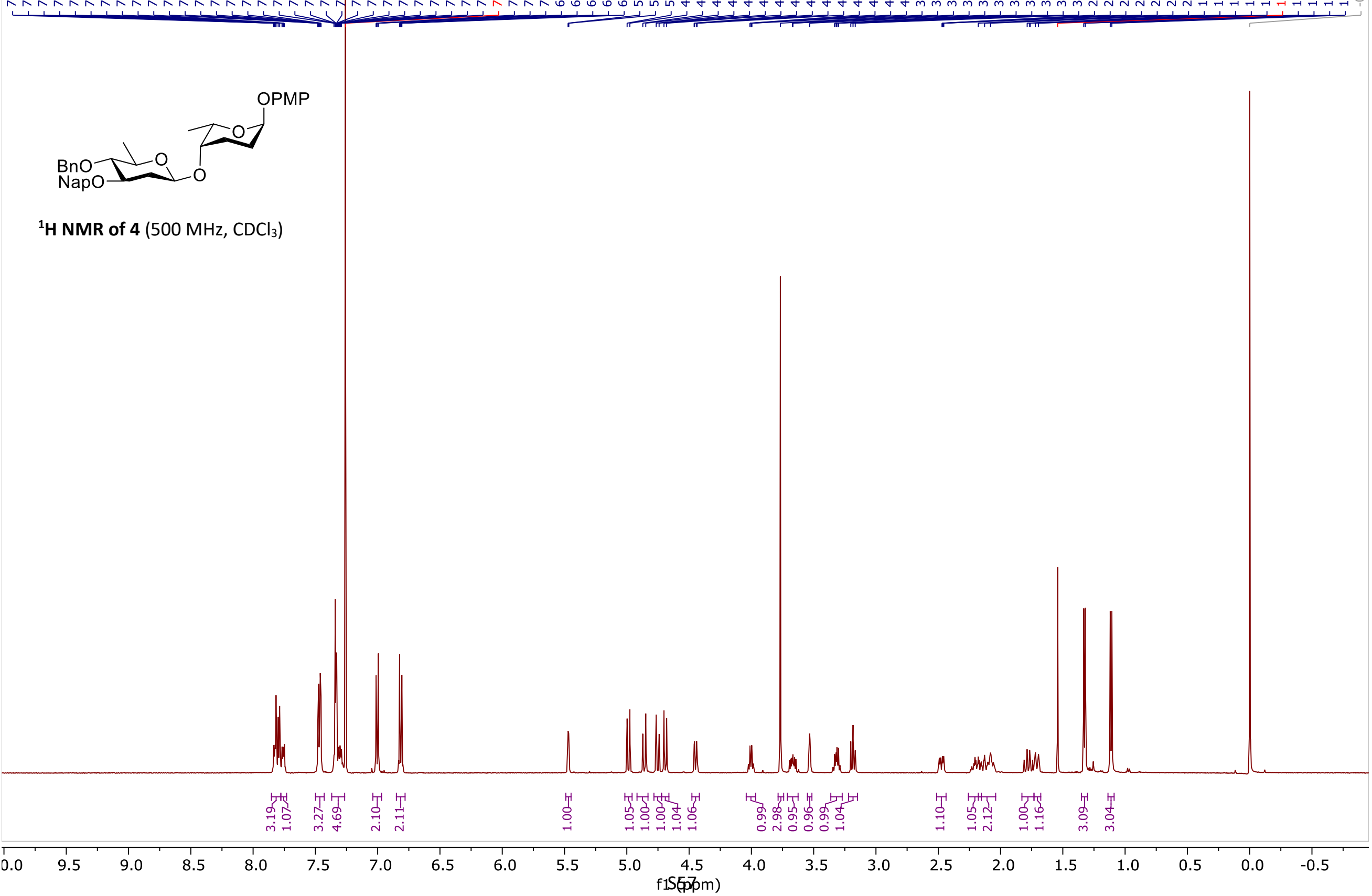


$\mathrm{N}_{1}$

OPMP

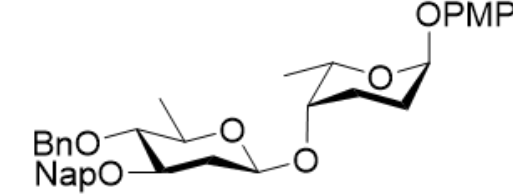

${ }^{13} \mathrm{C} \mathrm{NMR}$ of $4\left(126 \mathrm{MHz}, \mathrm{CDCl}_{3}\right)$

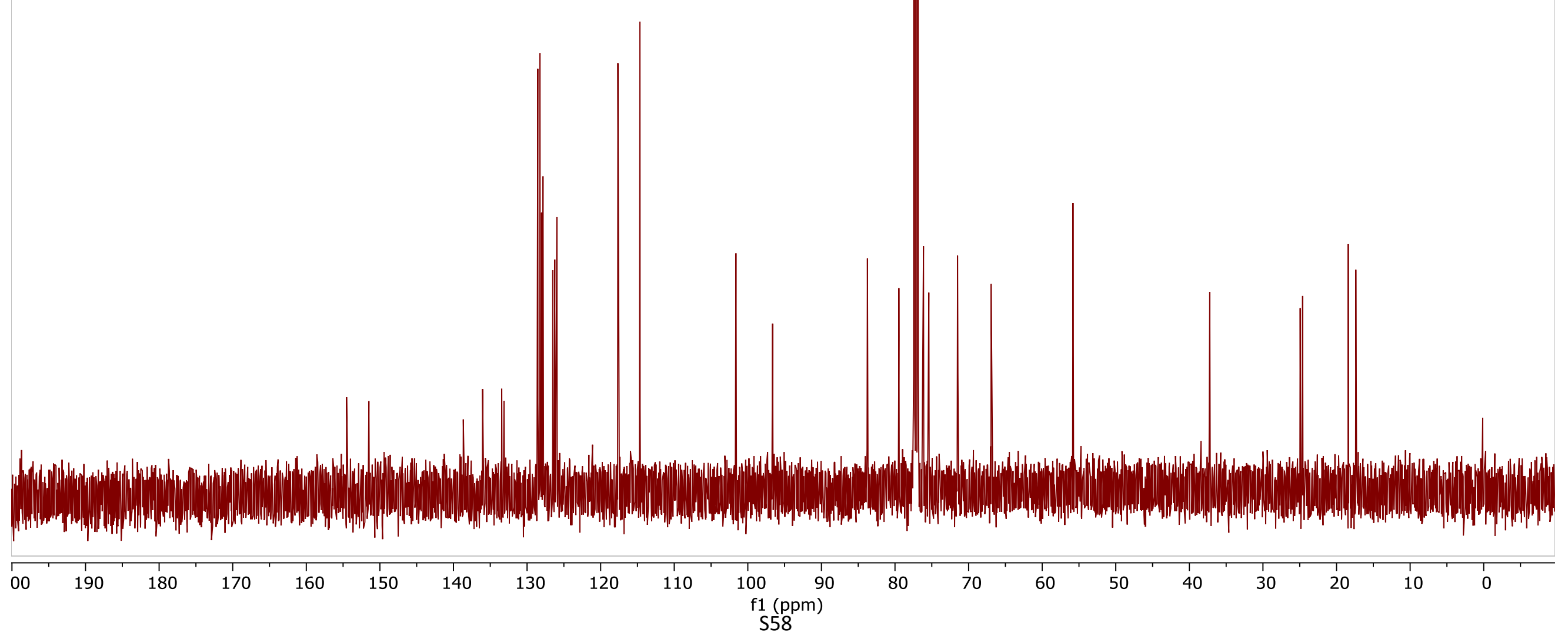


H- ${ }^{13} \mathbf{C ~ G r}$. HSQC of $4\left(500 \mathrm{MHz}, \mathrm{CDCl}_{3}\right)$

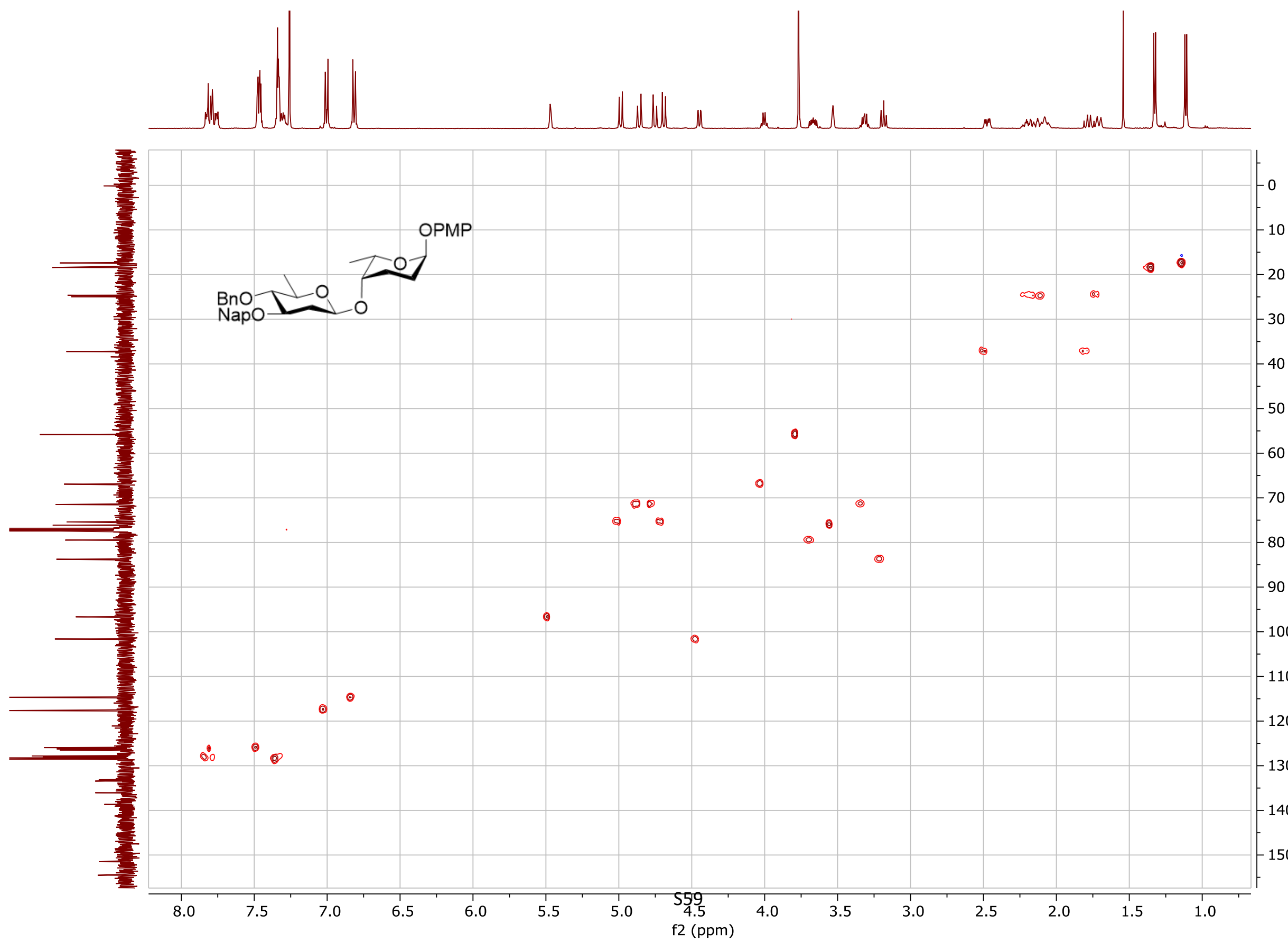


${ }^{1} \mathbf{H}-{ }^{1} \mathbf{H}$ Gr. COSY of $4\left(500 \mathrm{MHz}, \mathrm{CDCl}_{3}\right)$

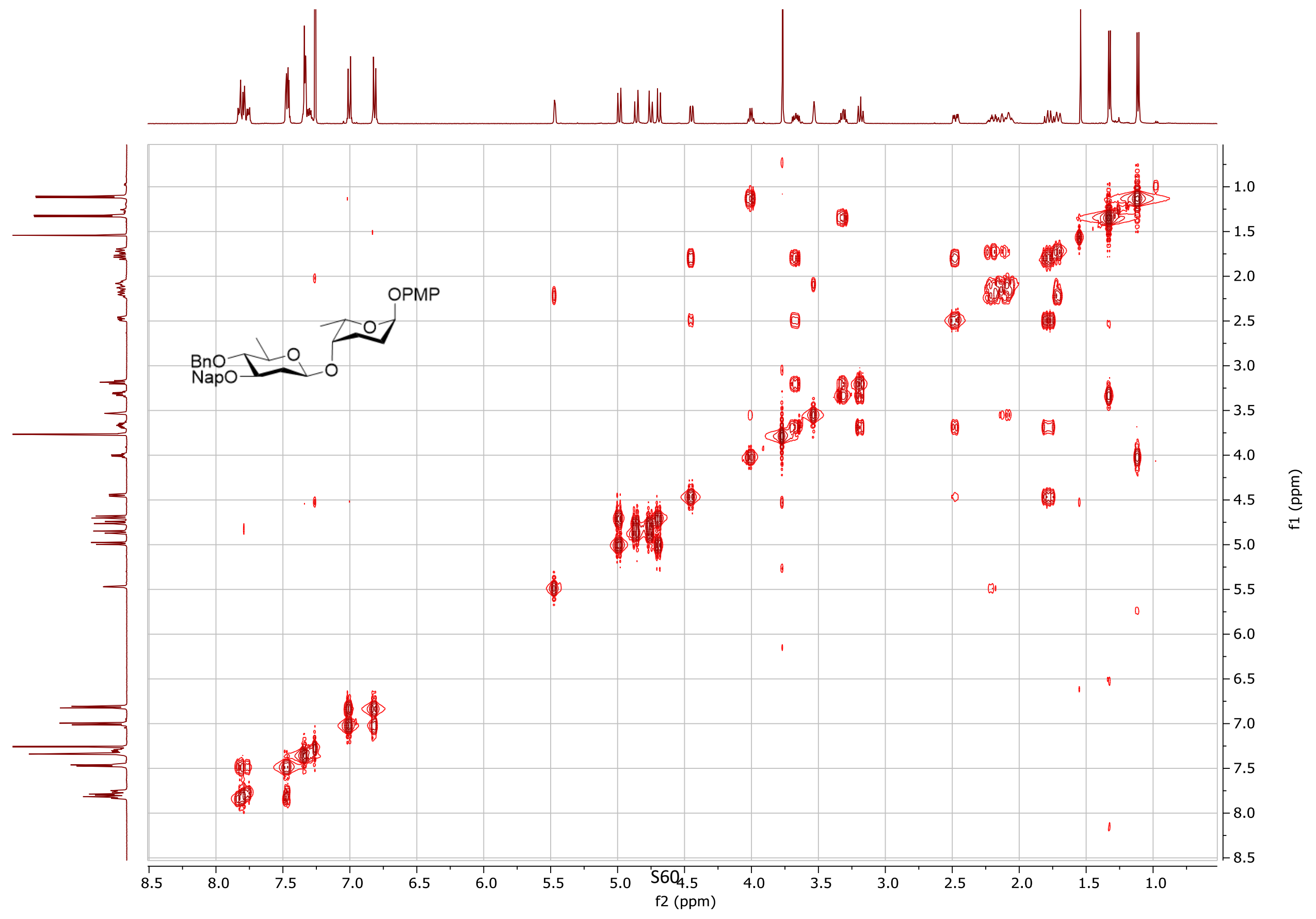




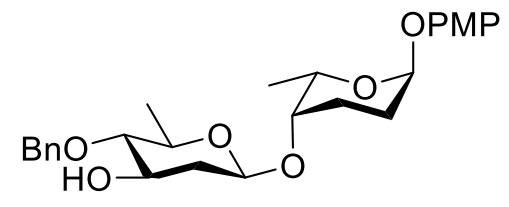

${ }^{1} \mathrm{H}$ NMR of $16\left(500 \mathrm{MHz}, \mathrm{CDCl}_{3}\right)$

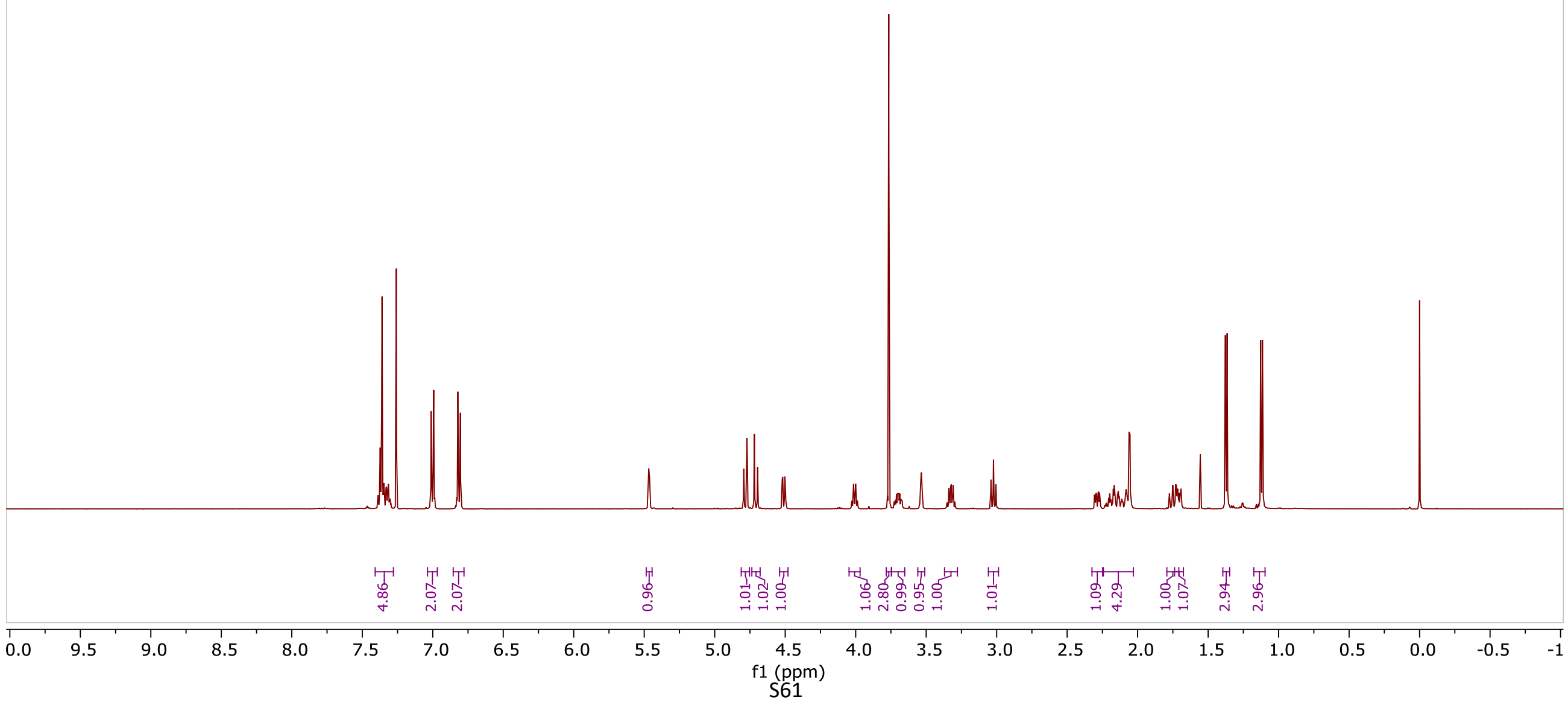




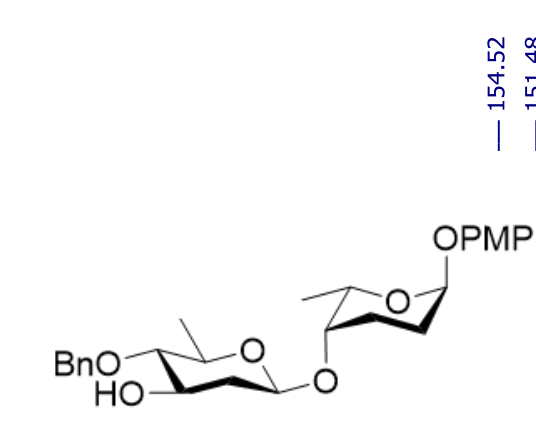

|

${ }^{13} \mathrm{C}$ NMR of $16\left(126 \mathrm{MHz}, \mathrm{CDCl}_{3}\right)$

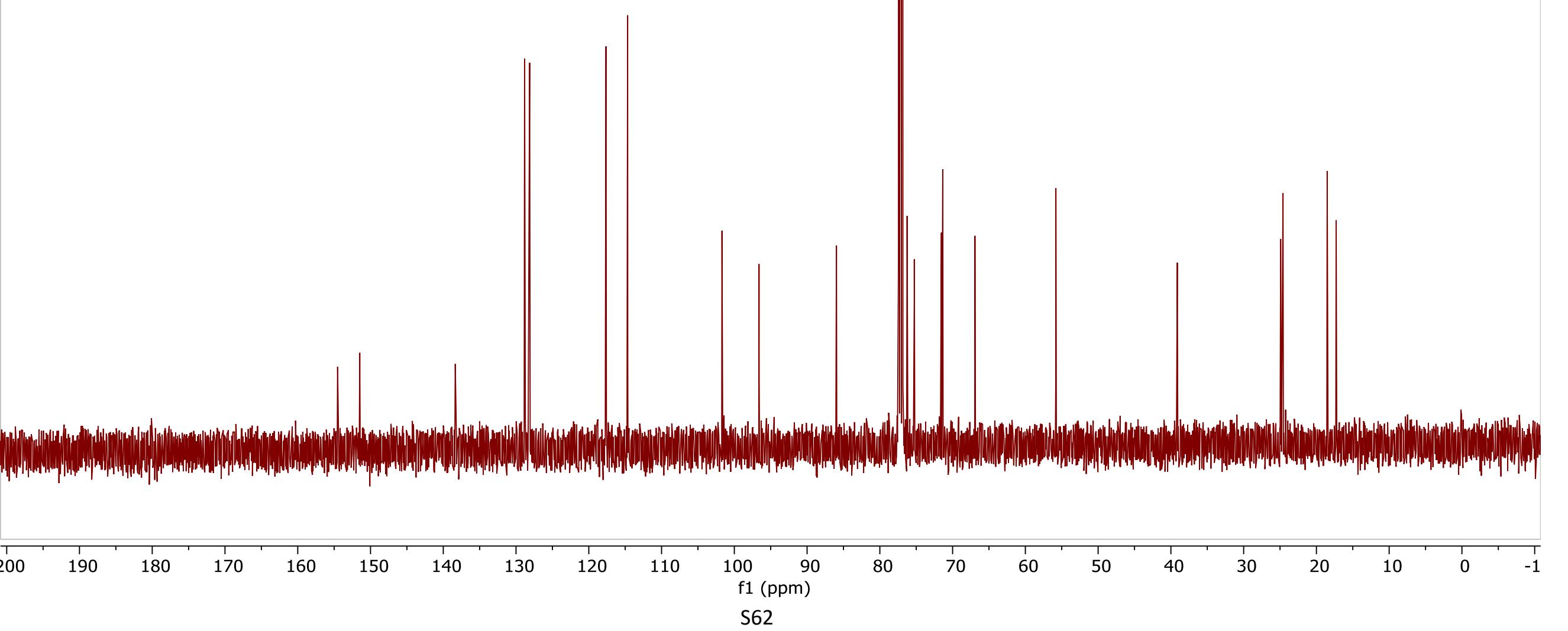




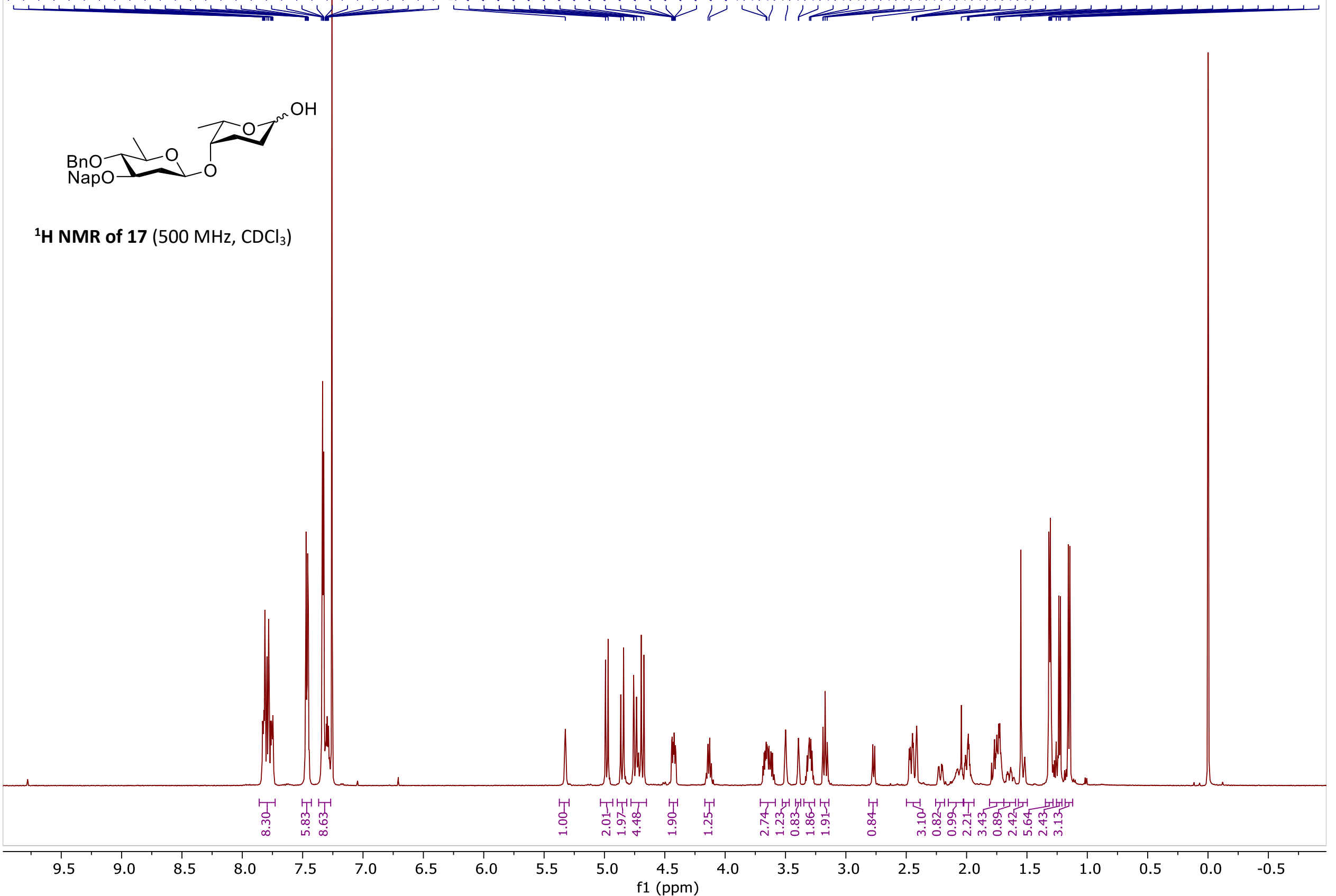




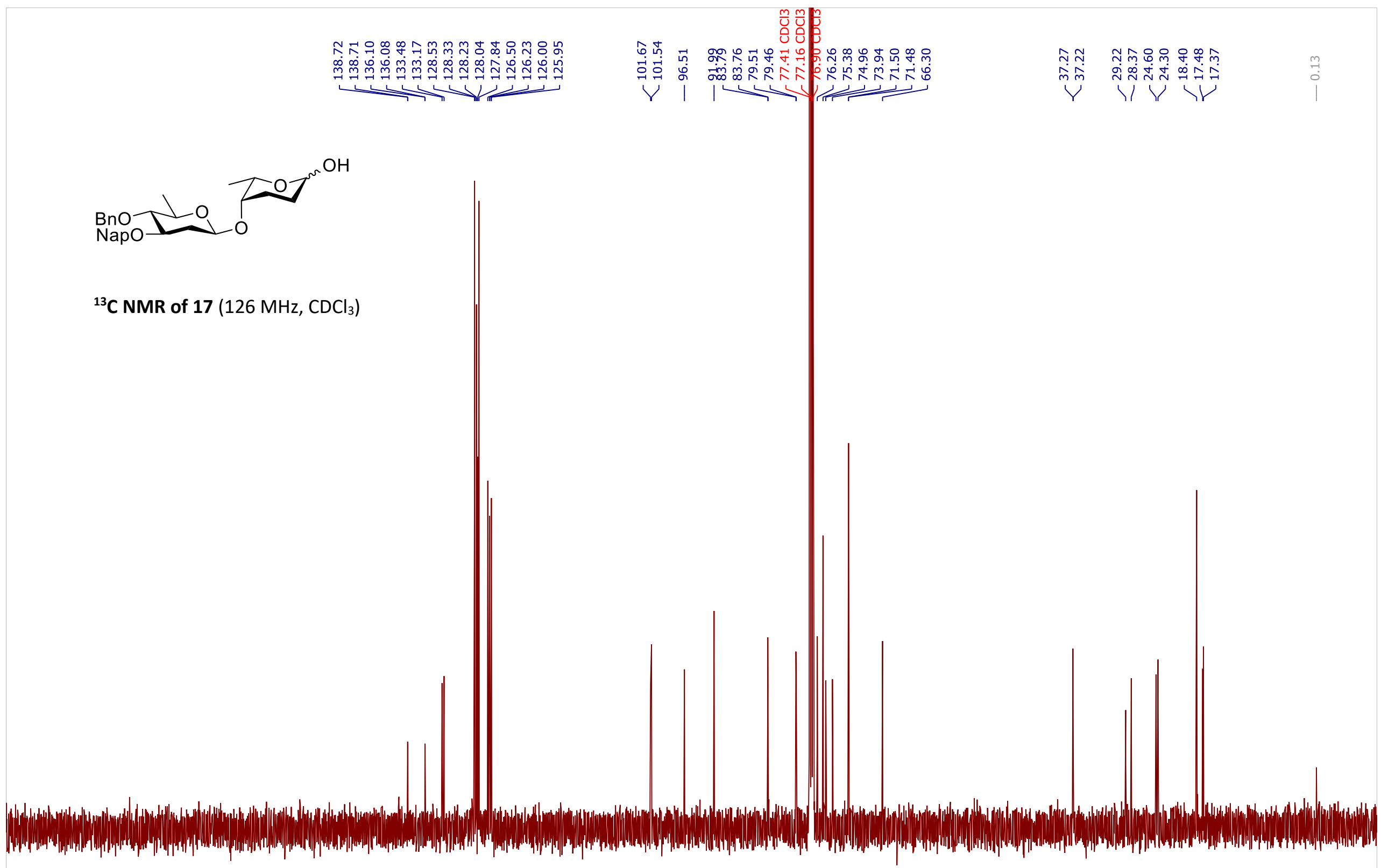

$190 \quad 180$

$80 \quad 170$

160

150

$140 \quad 130$

120

110 100 f1 (ppm)
(p)

80

70

60

50

40 

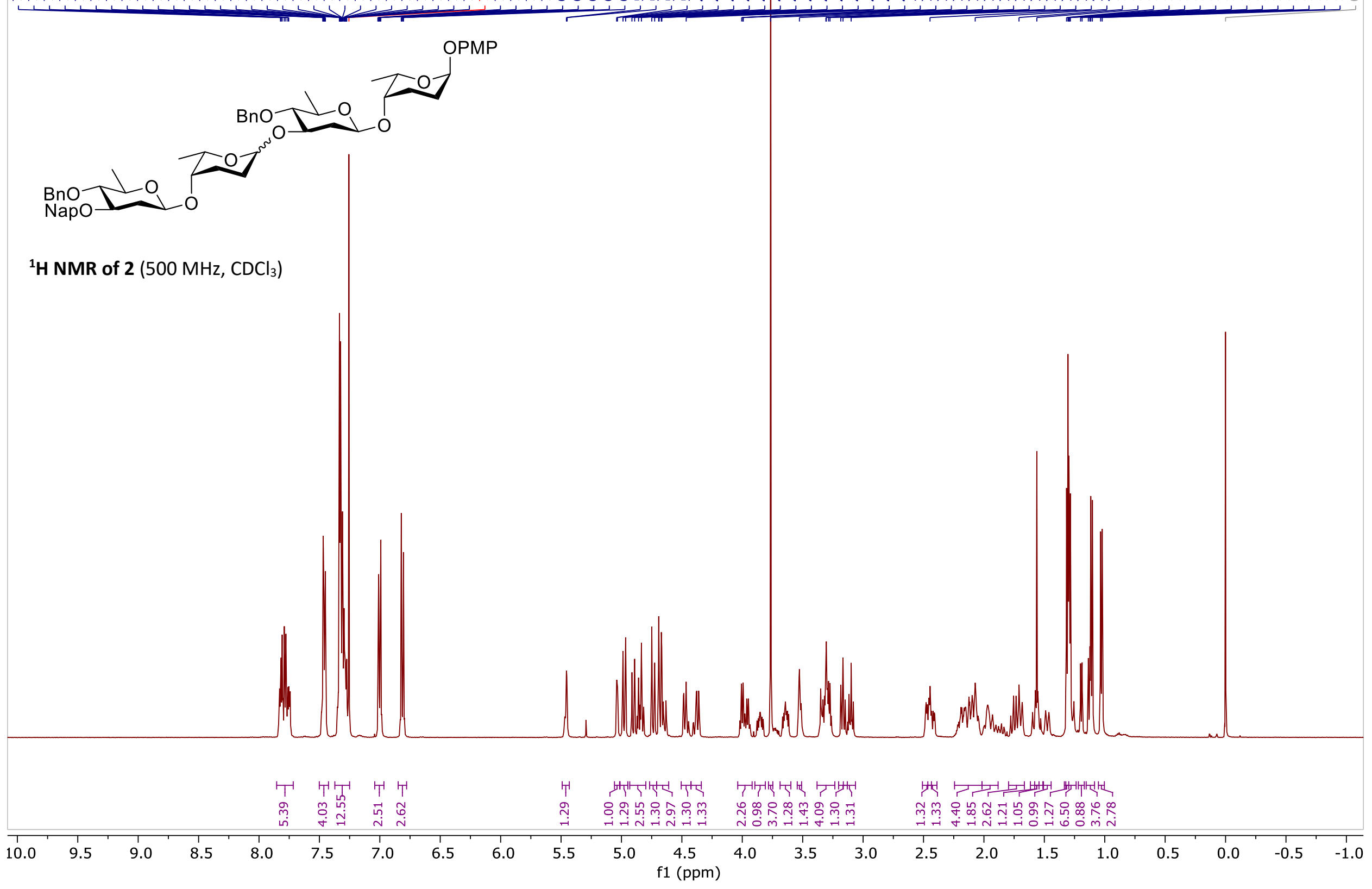


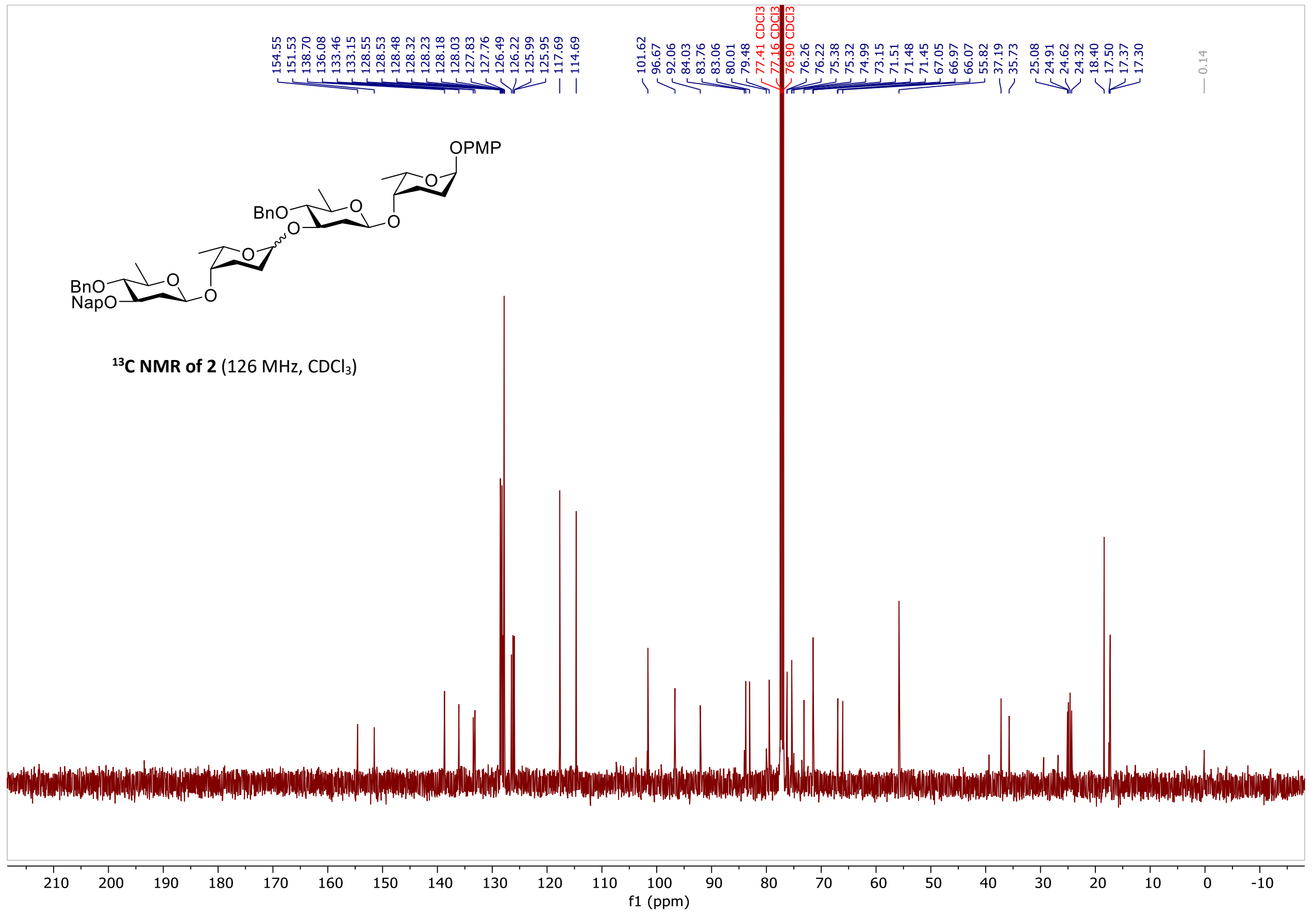


荇

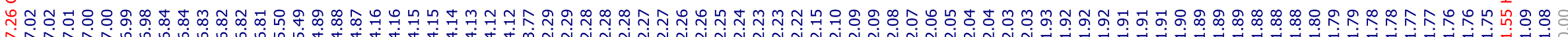

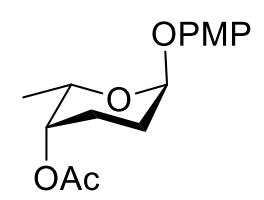

${ }^{1} \mathbf{H}$ NMR of $20\left(500 \mathrm{MHz}, \mathrm{CDCl}_{3}\right)$

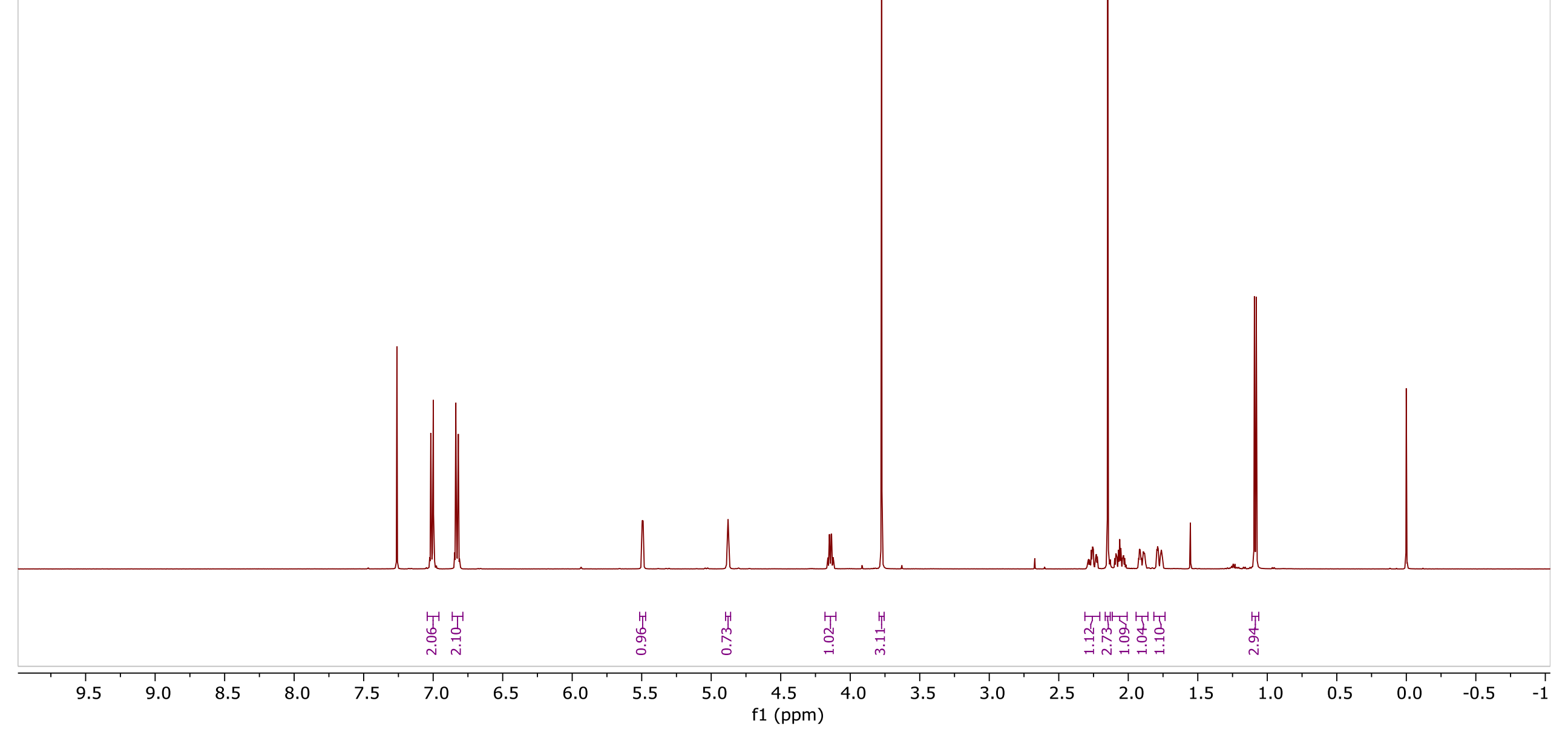




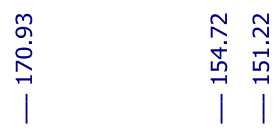

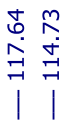

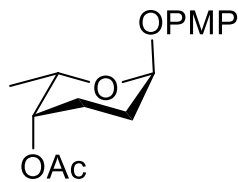

${ }^{13} \mathrm{C}$ NMR of $20\left(126 \mathrm{MHz}, \mathrm{CDCl}_{3}\right)$

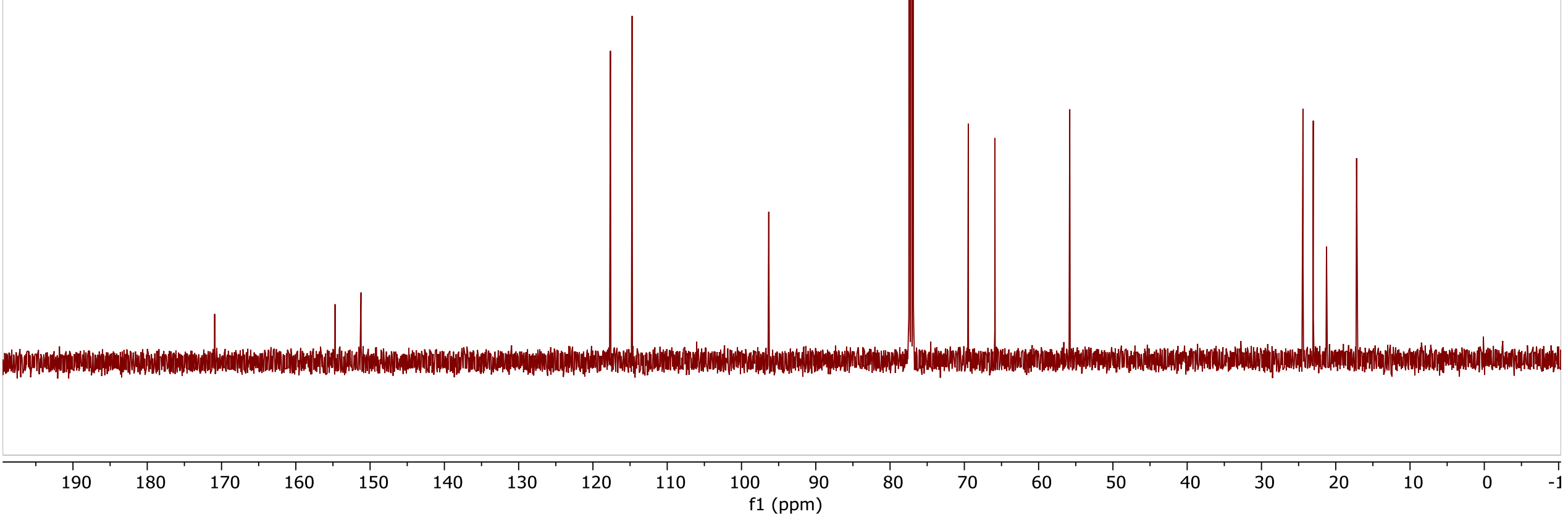




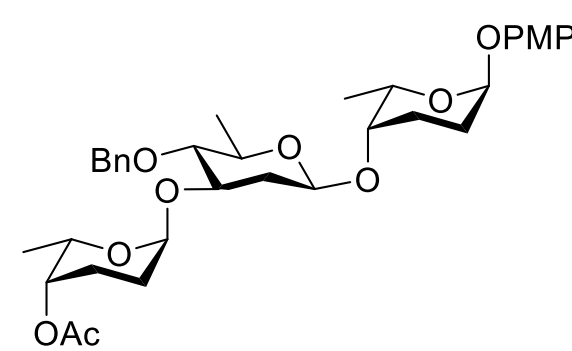

${ }^{1} \mathrm{H}$ NMR of $21\left(500 \mathrm{MHz}, \mathrm{CDCl}_{3}\right)$

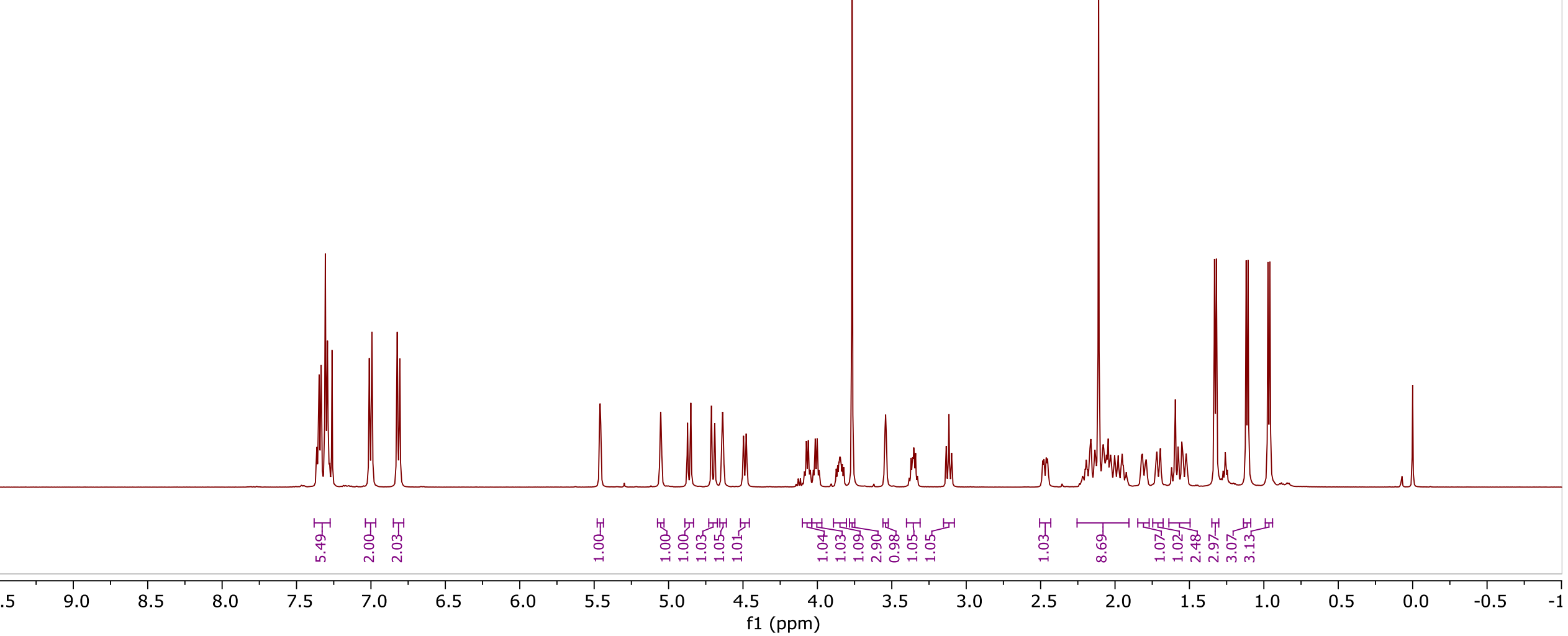




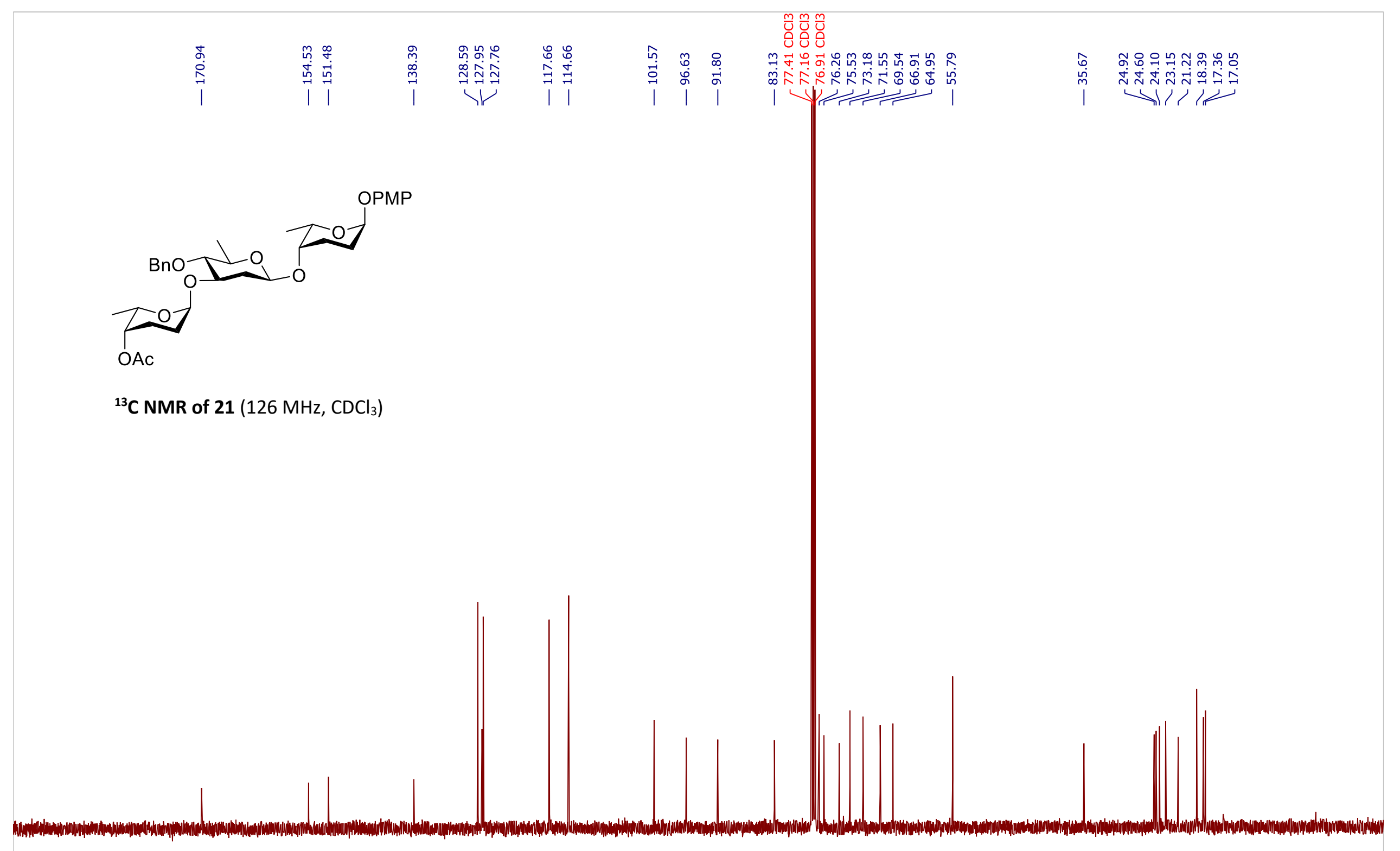

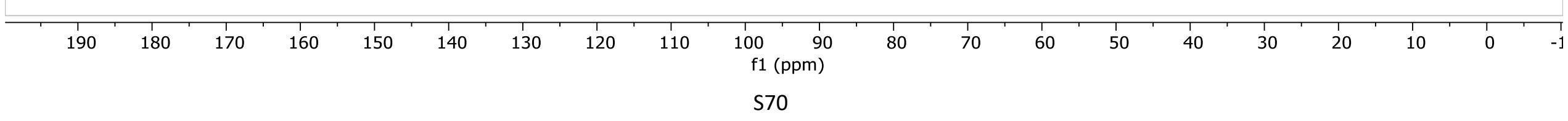


${ }^{1} \mathrm{H}-{ }^{1} \mathrm{H}$ Gr. COSY of $21\left(500 \mathrm{MHz}, \mathrm{CDCl}_{3}\right)$

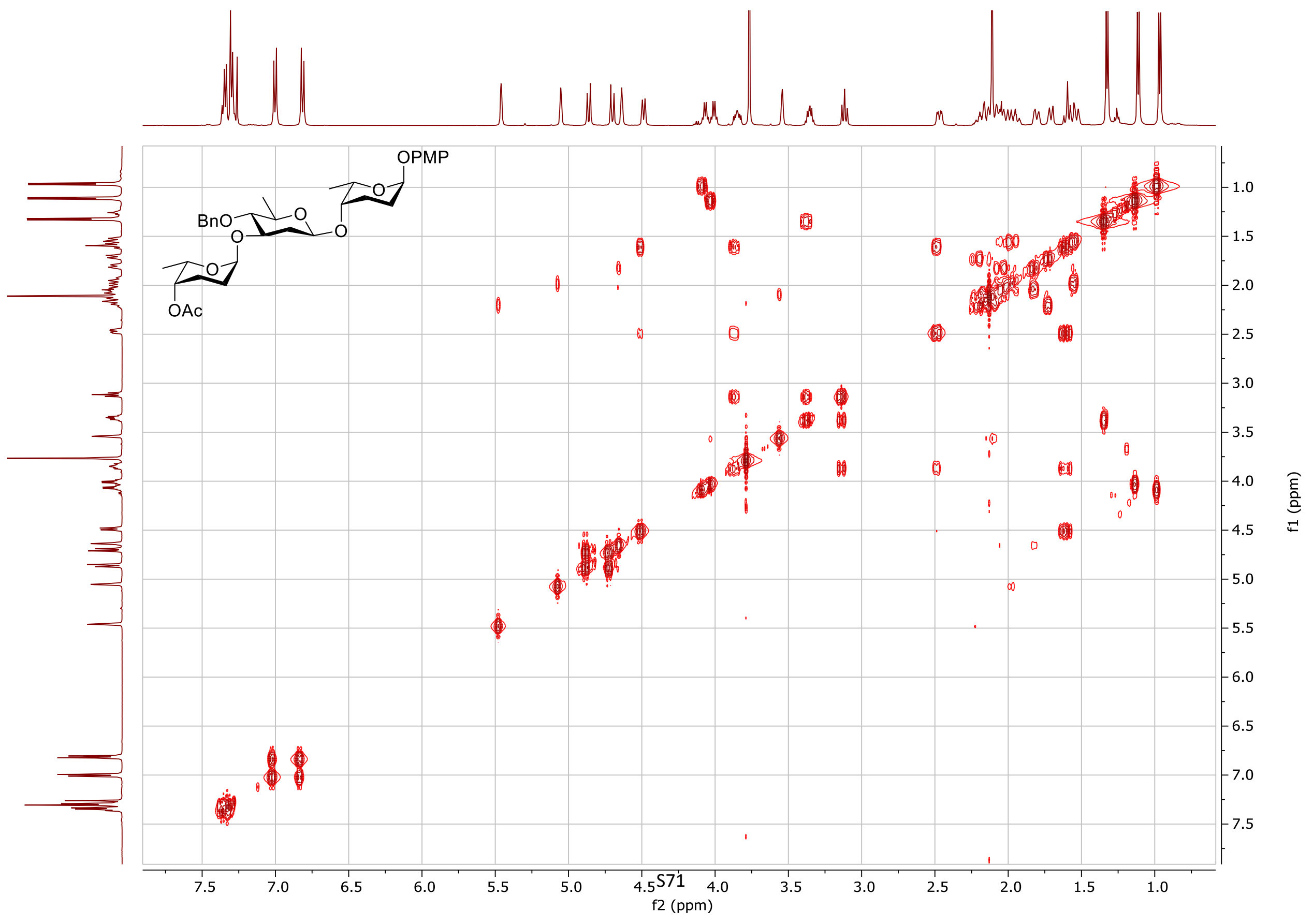


${ }^{1} \mathrm{H}-{ }^{1} \mathrm{H}$ Gr. HSQC of $21\left(500 \mathrm{MHz}, \mathrm{CDCl}_{3}\right)$

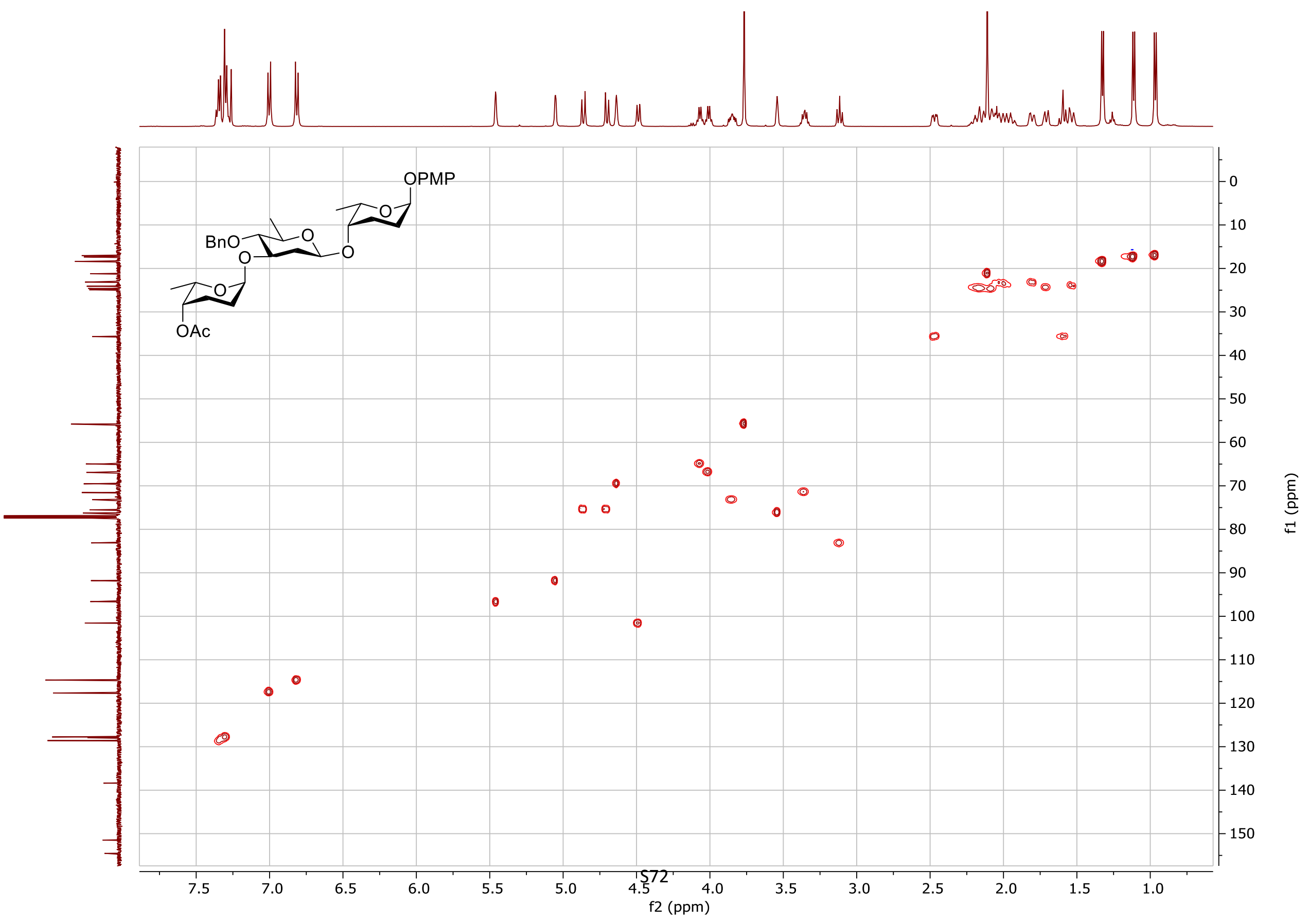



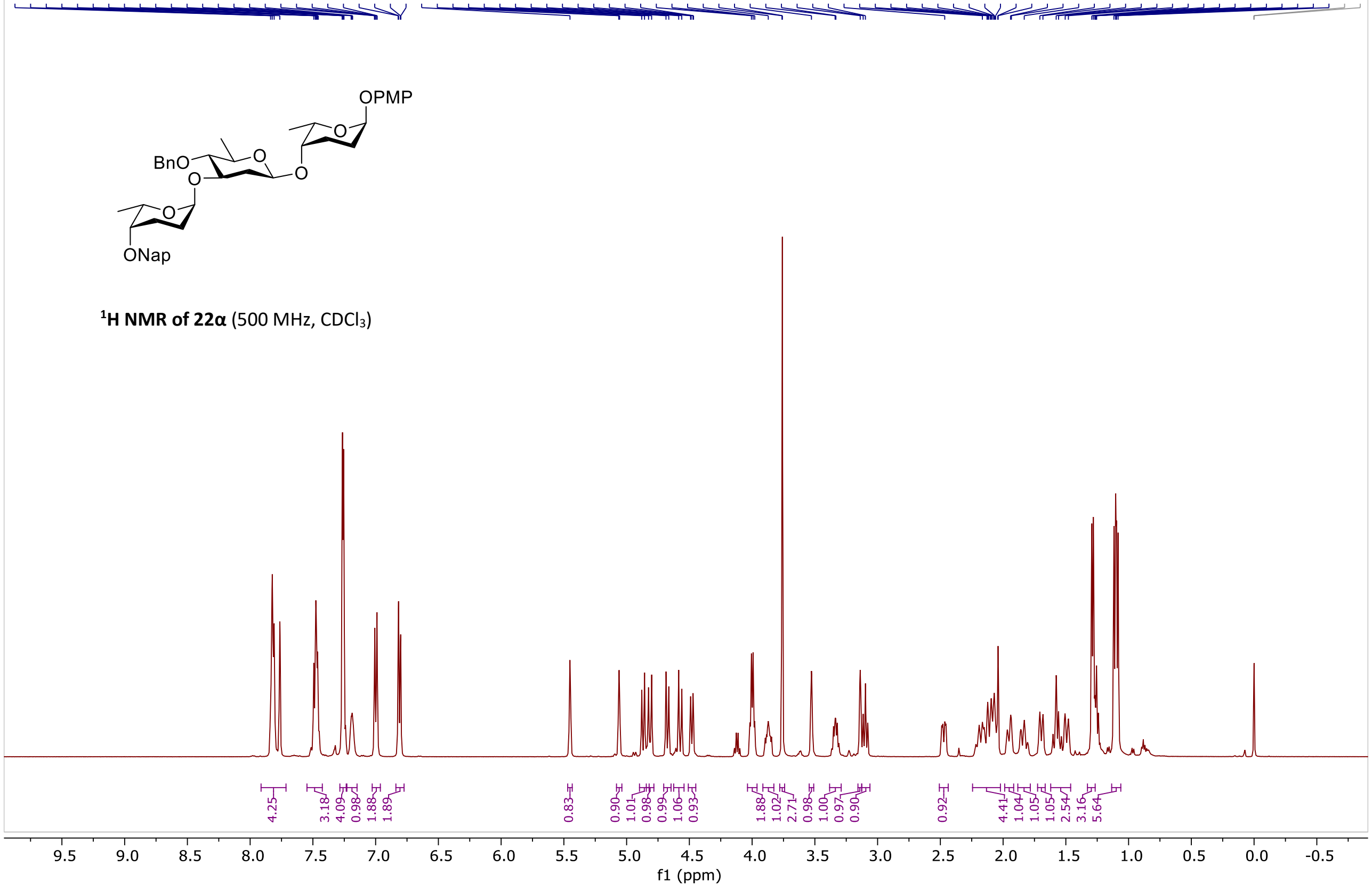


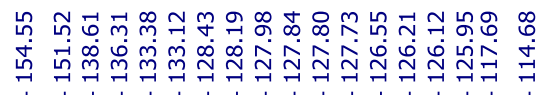

|

OPMP

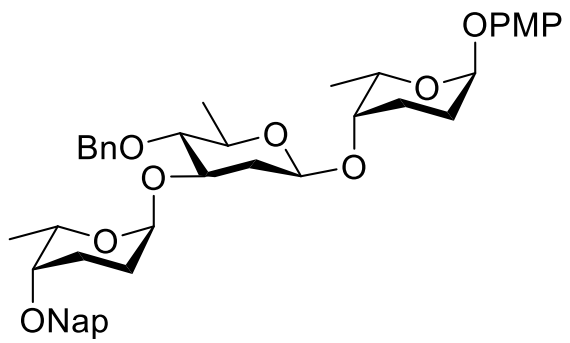

${ }^{13} \mathrm{C}$ NMR of $22 \alpha\left(126 \mathrm{MHz}, \mathrm{CDCl}_{3}\right)$

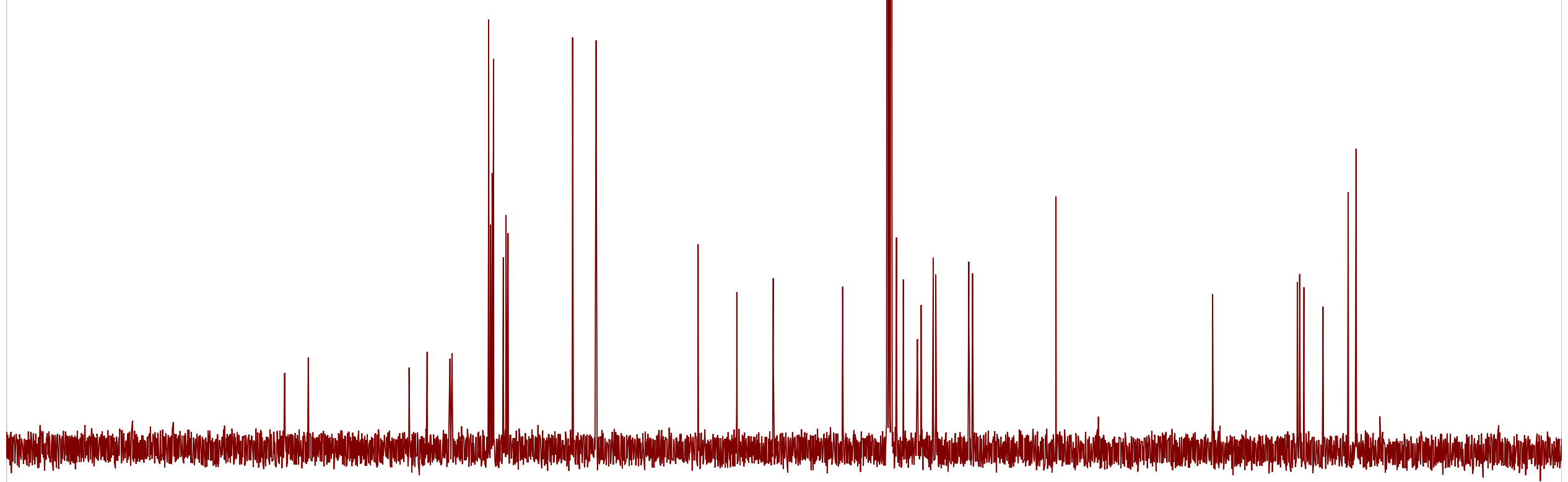

$90 \quad 180 \quad 170 \quad 160$

150

140

$130 \quad 120$

$110 \quad 100$

90
$1(\mathrm{ppm})$

$80 \quad 70$

60

50

40

30

20

10 


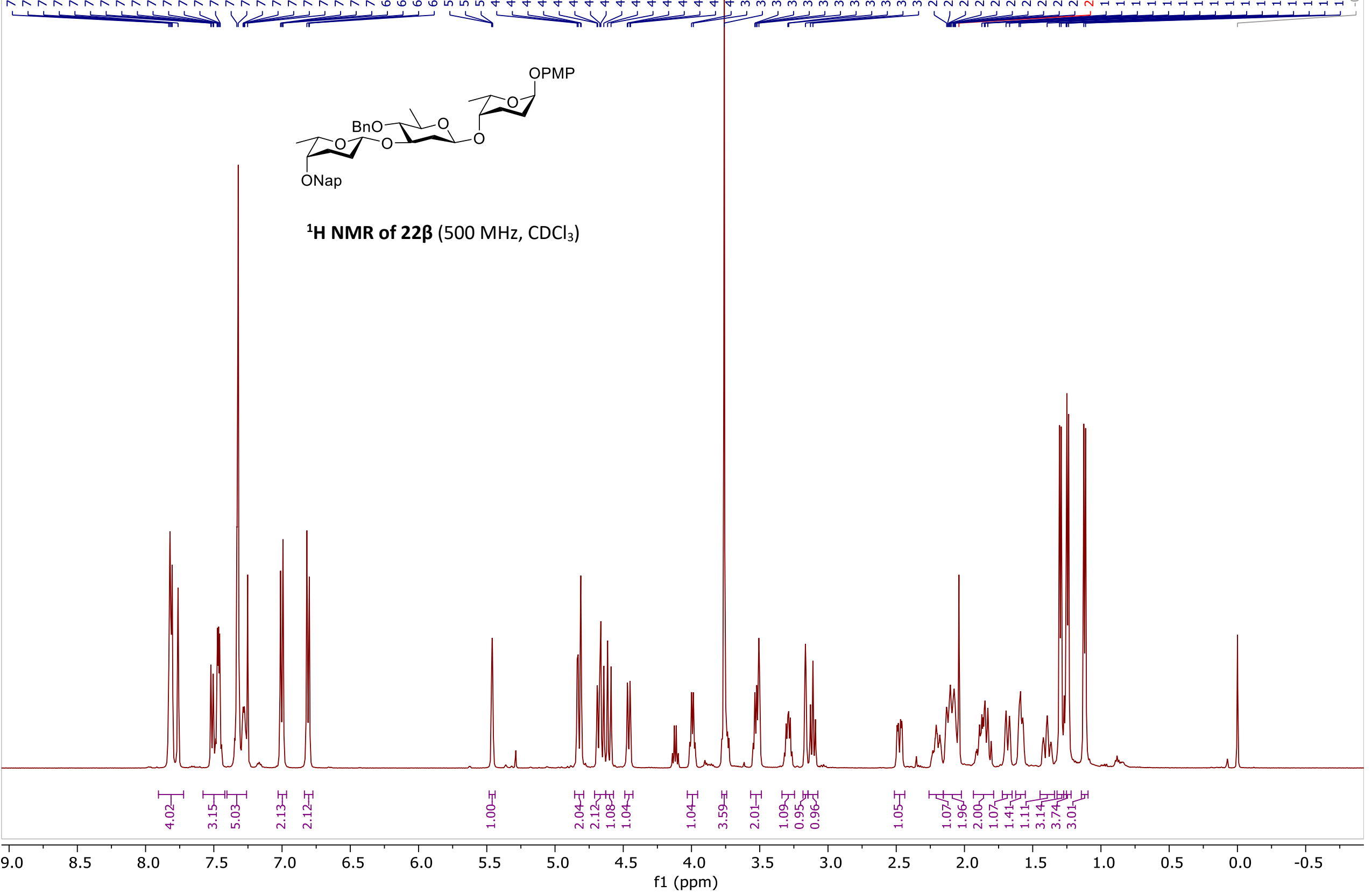




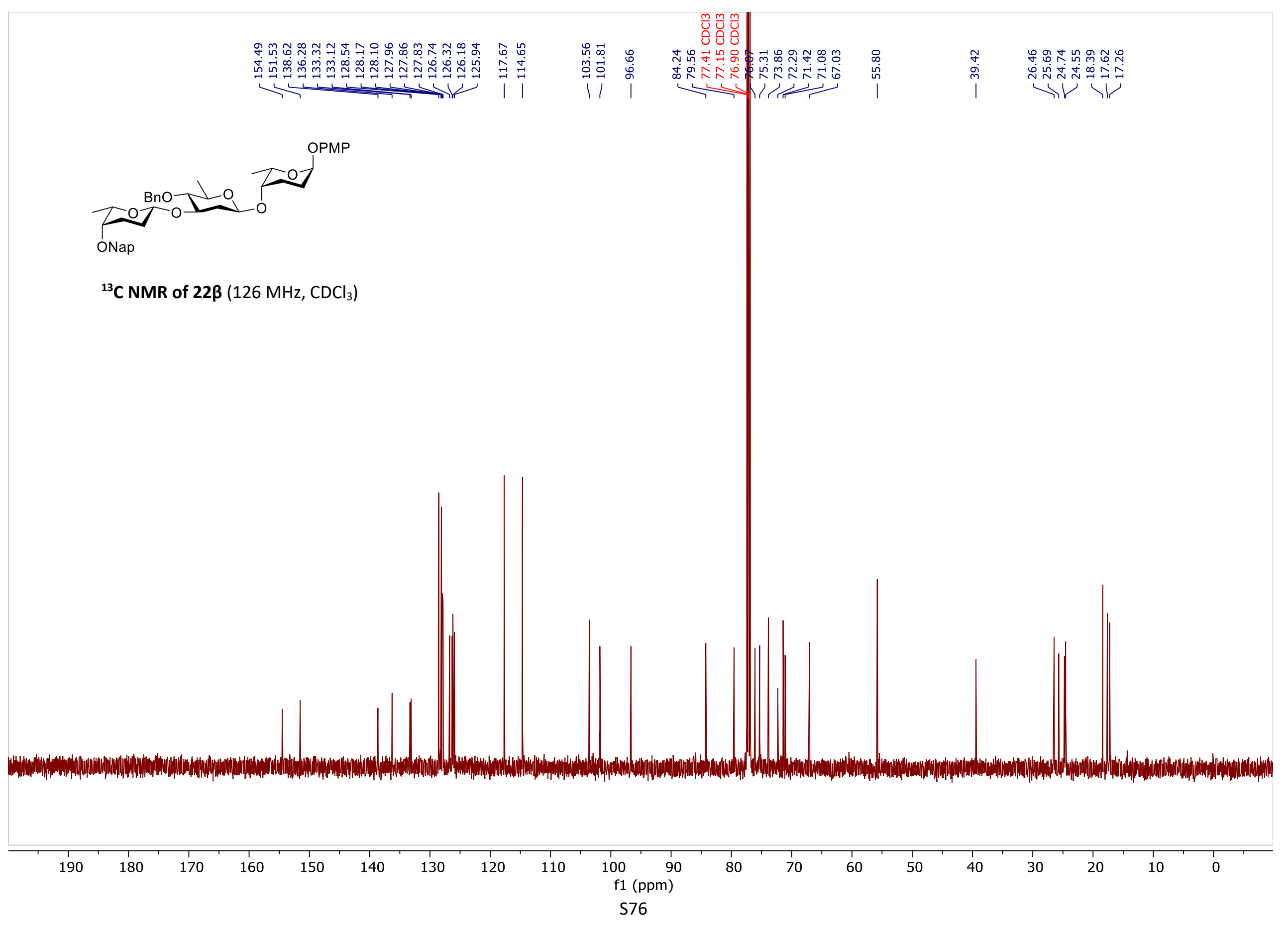




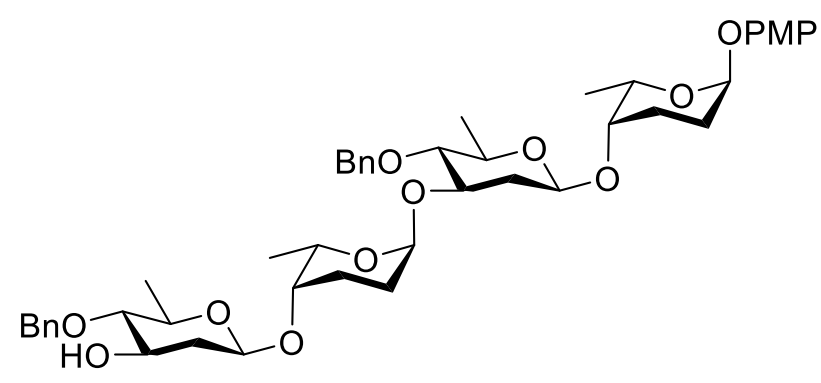

${ }^{1} \mathrm{H}$ NMR of $18\left(500 \mathrm{MHz}, \mathrm{CDCl}_{3}\right)$
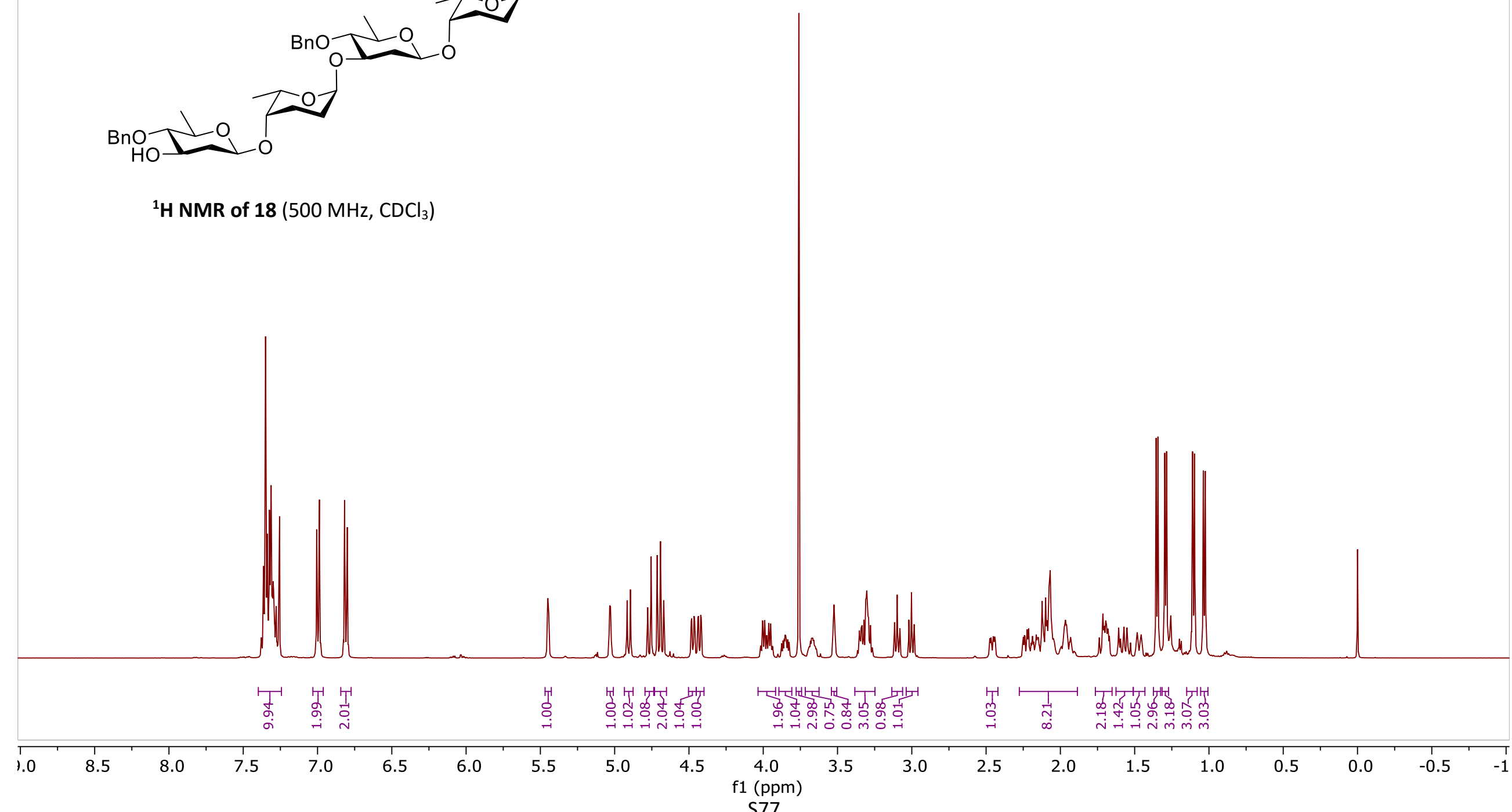


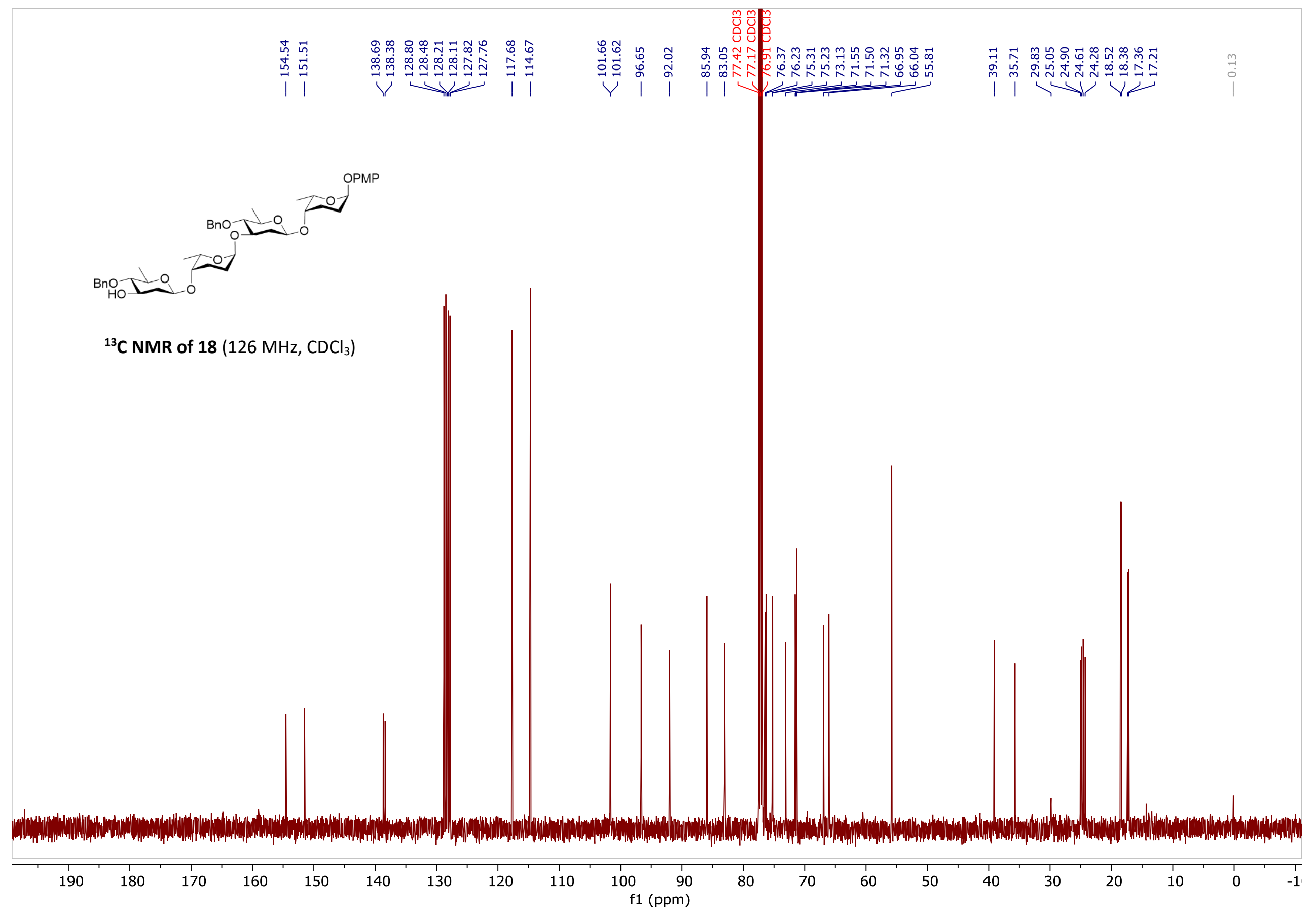




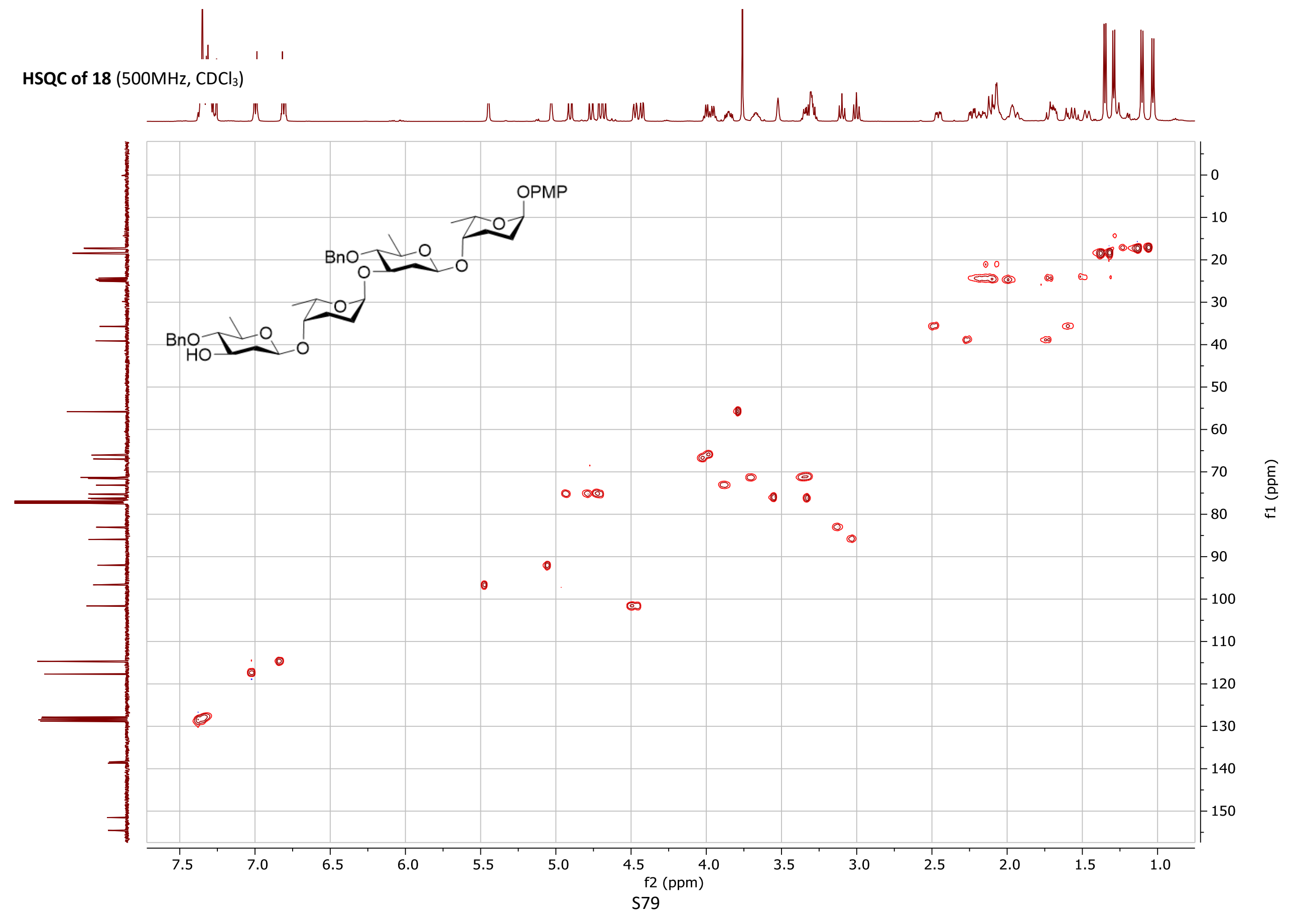




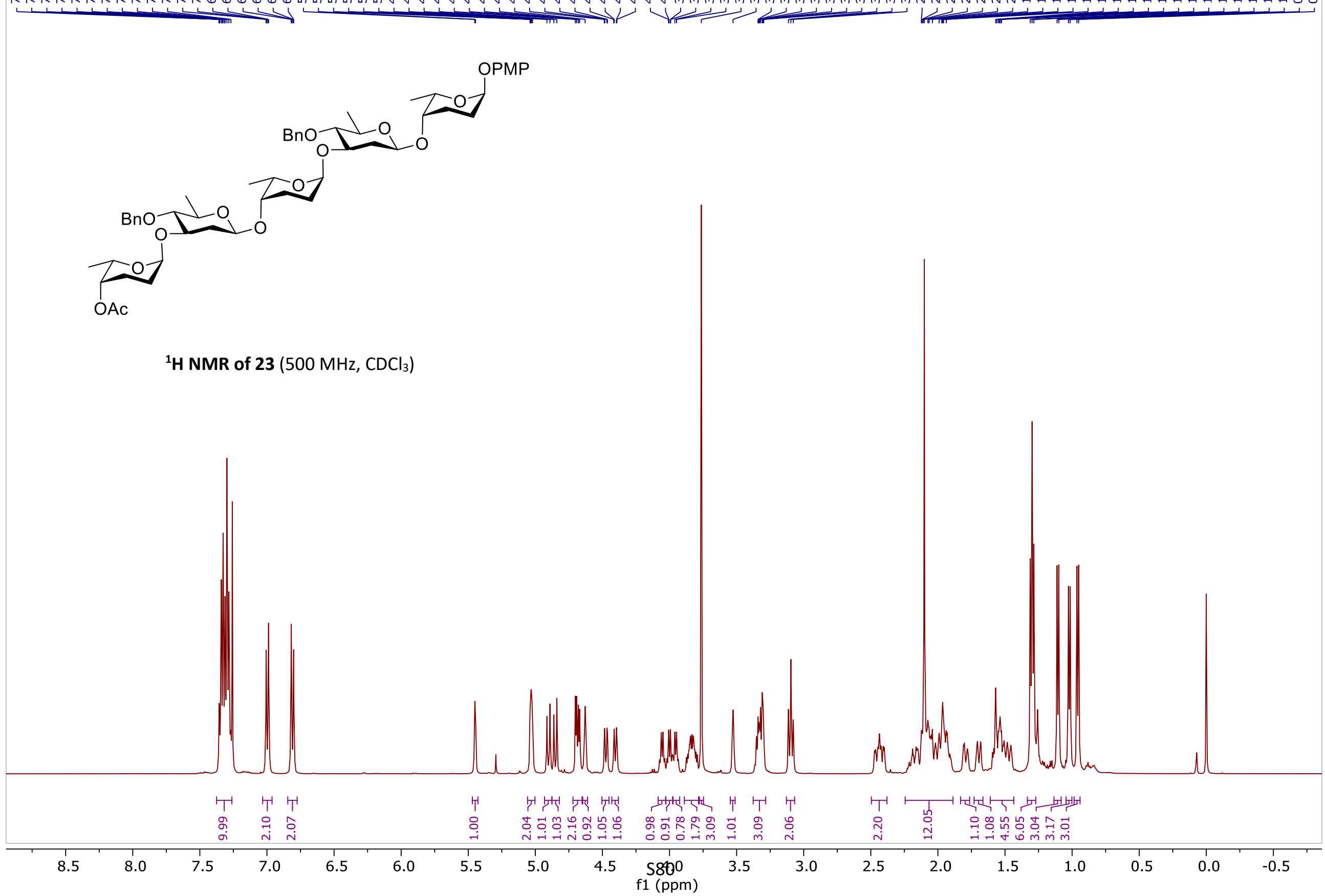




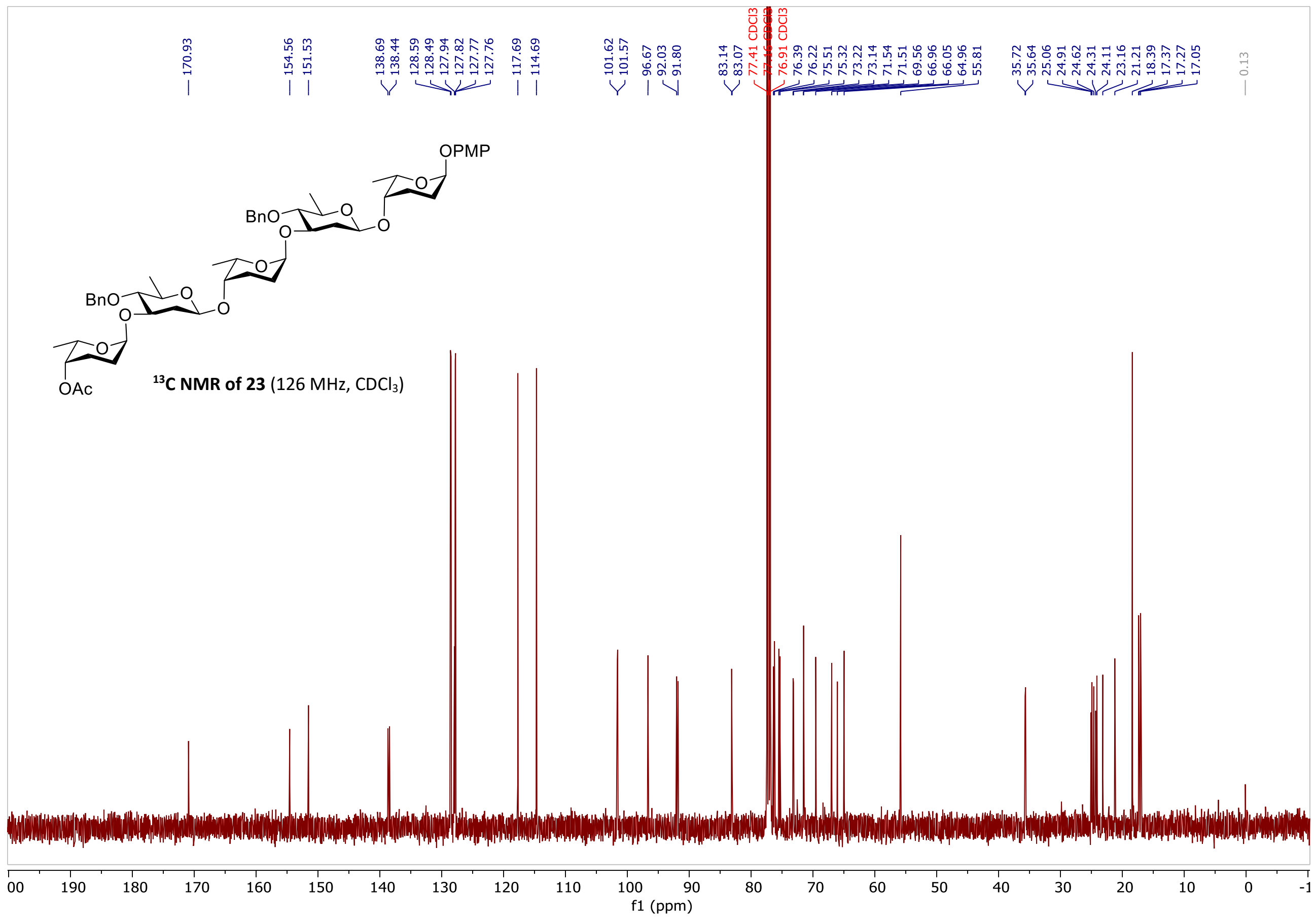


$\mathrm{H}-{ }^{13} \mathrm{C} \mathrm{Gr}$. HSQC (500 MHz, $\mathrm{CDCl}_{3}$ of 23)

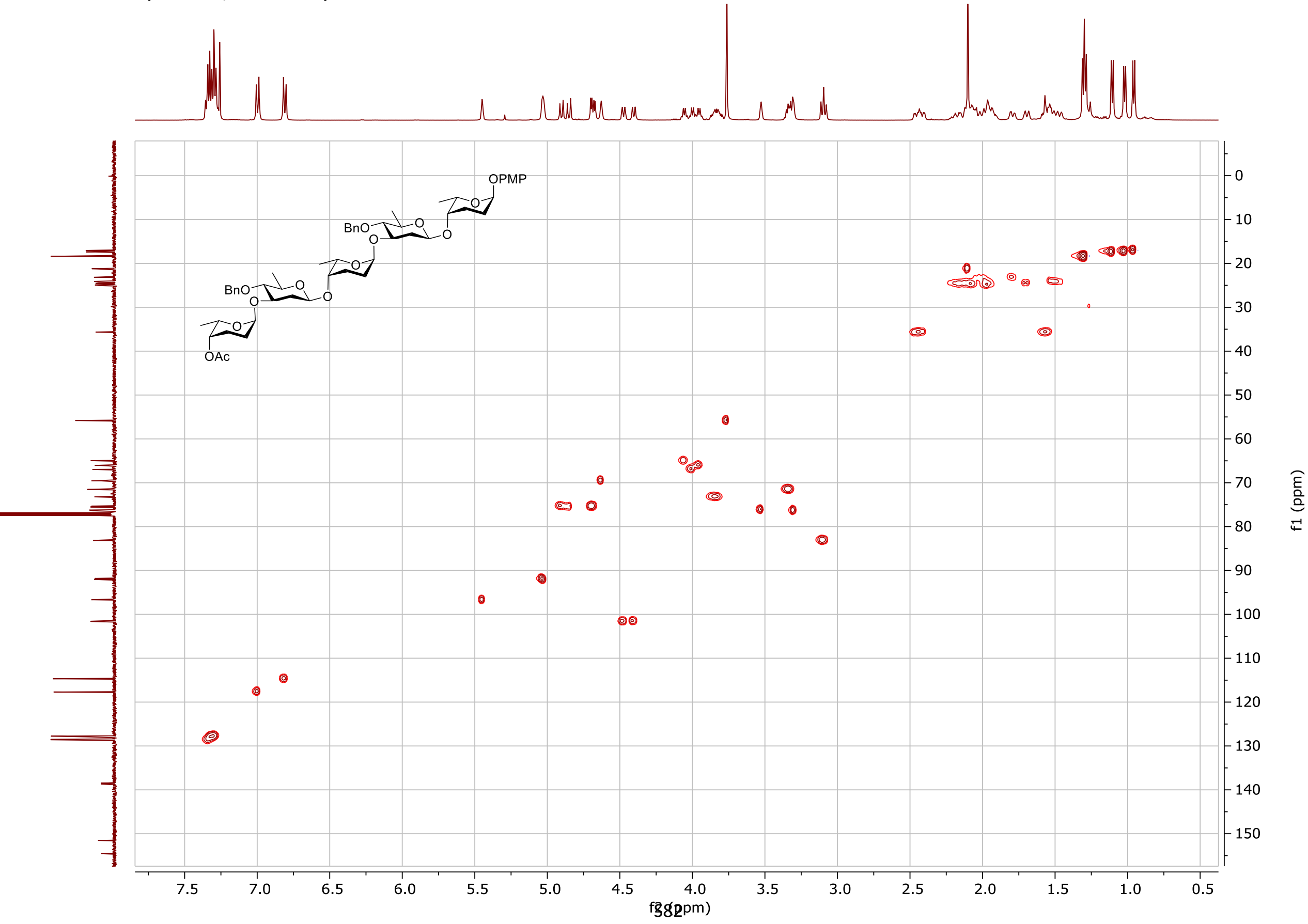




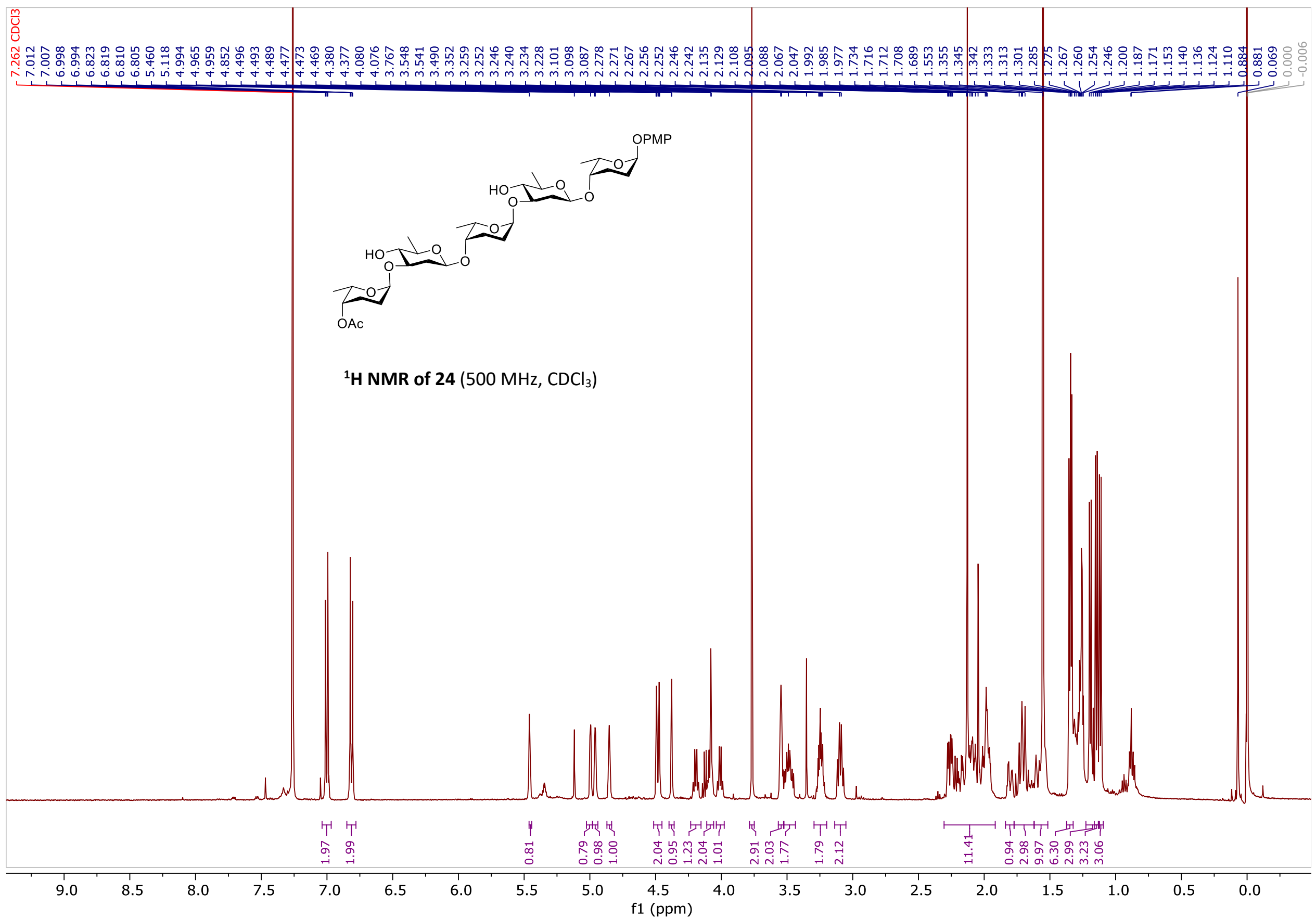


cosY of $24\left(500 \mathrm{MHz}, \mathrm{CDCl}_{3}\right)$

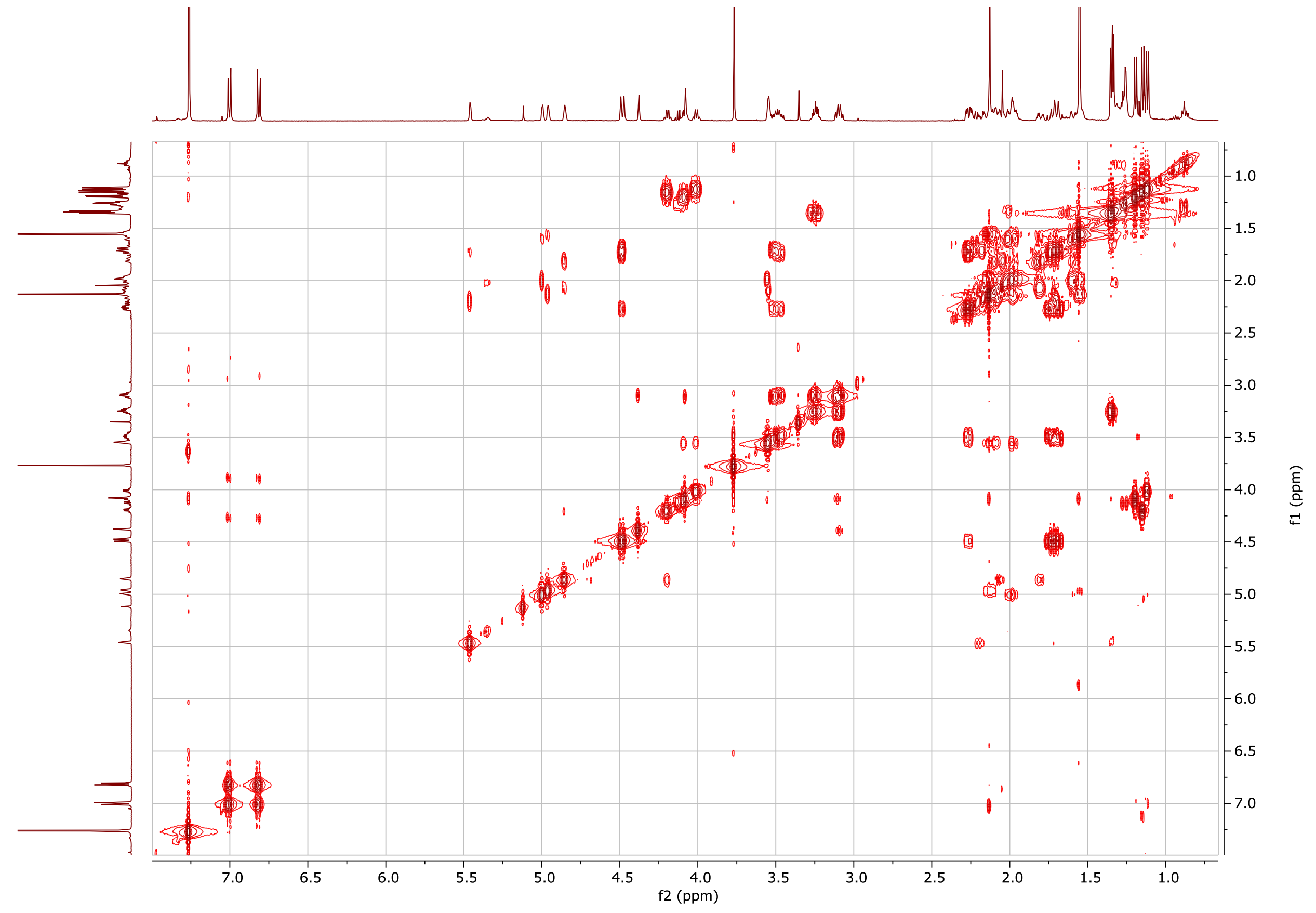




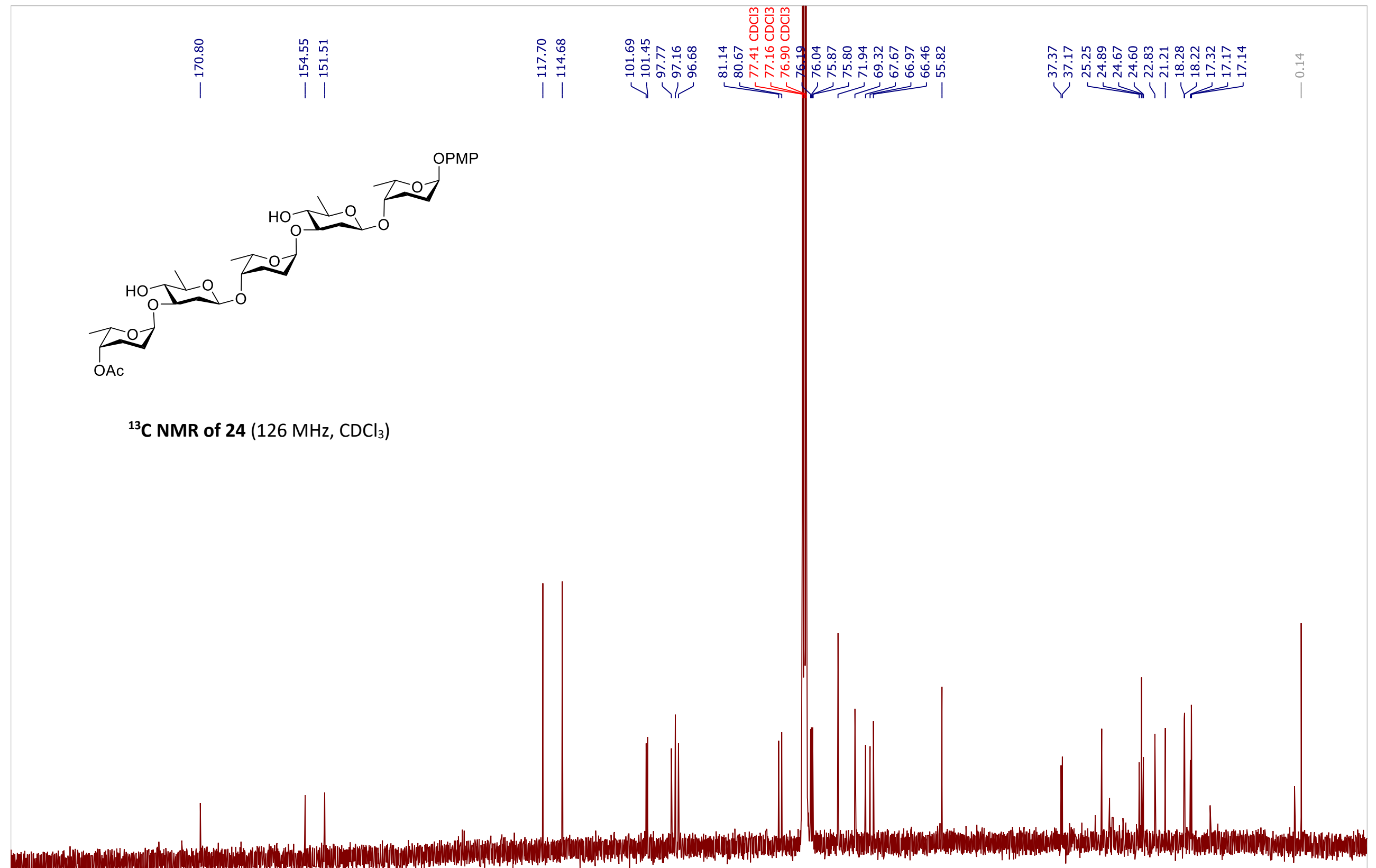

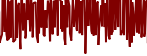

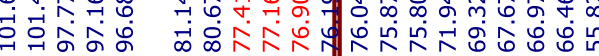

$Y$ M

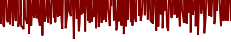

190

180

170

160

150

140

130

120

$110 \quad 100$

flopm)

80

$70 \quad 60$

50

40

30

20 


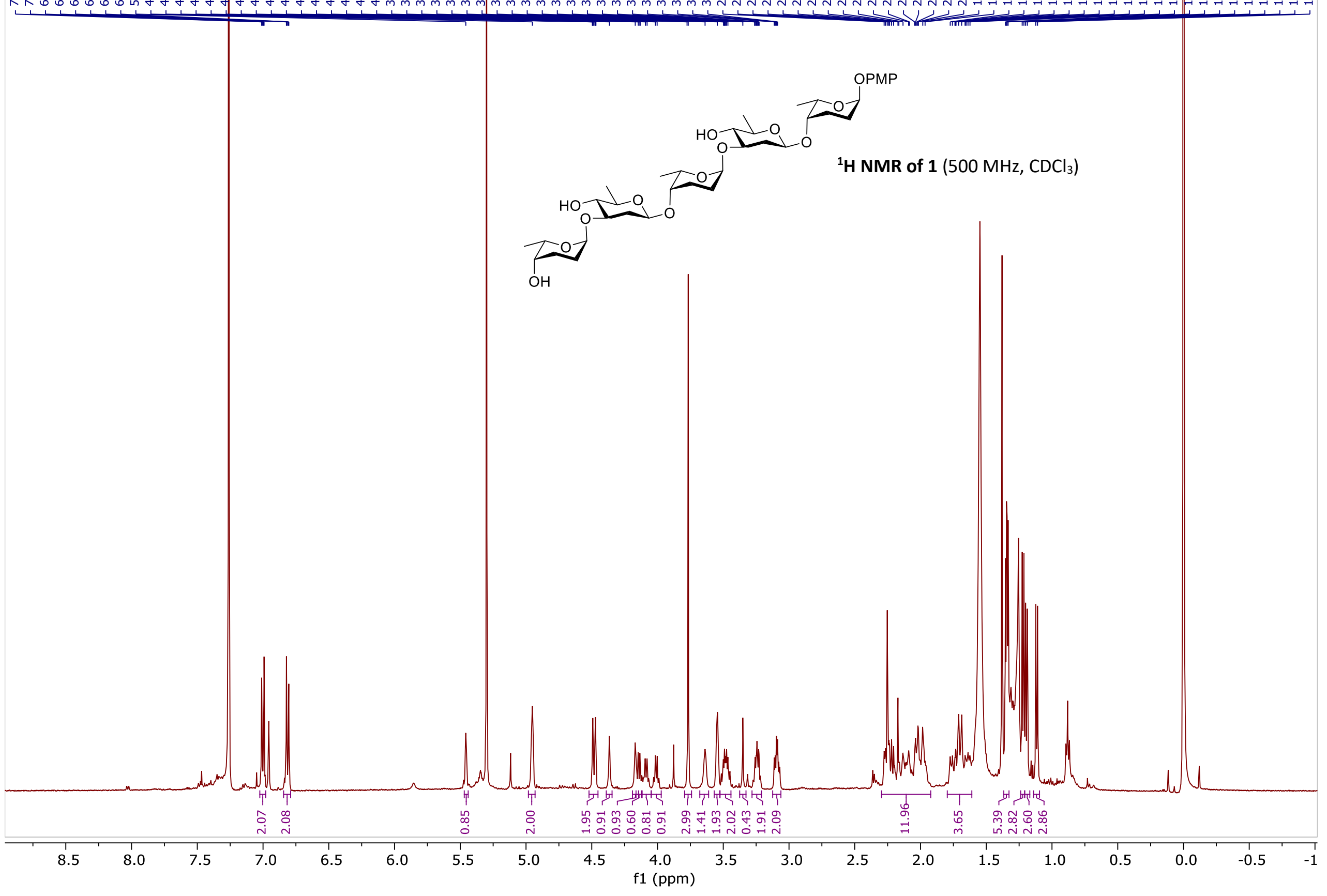




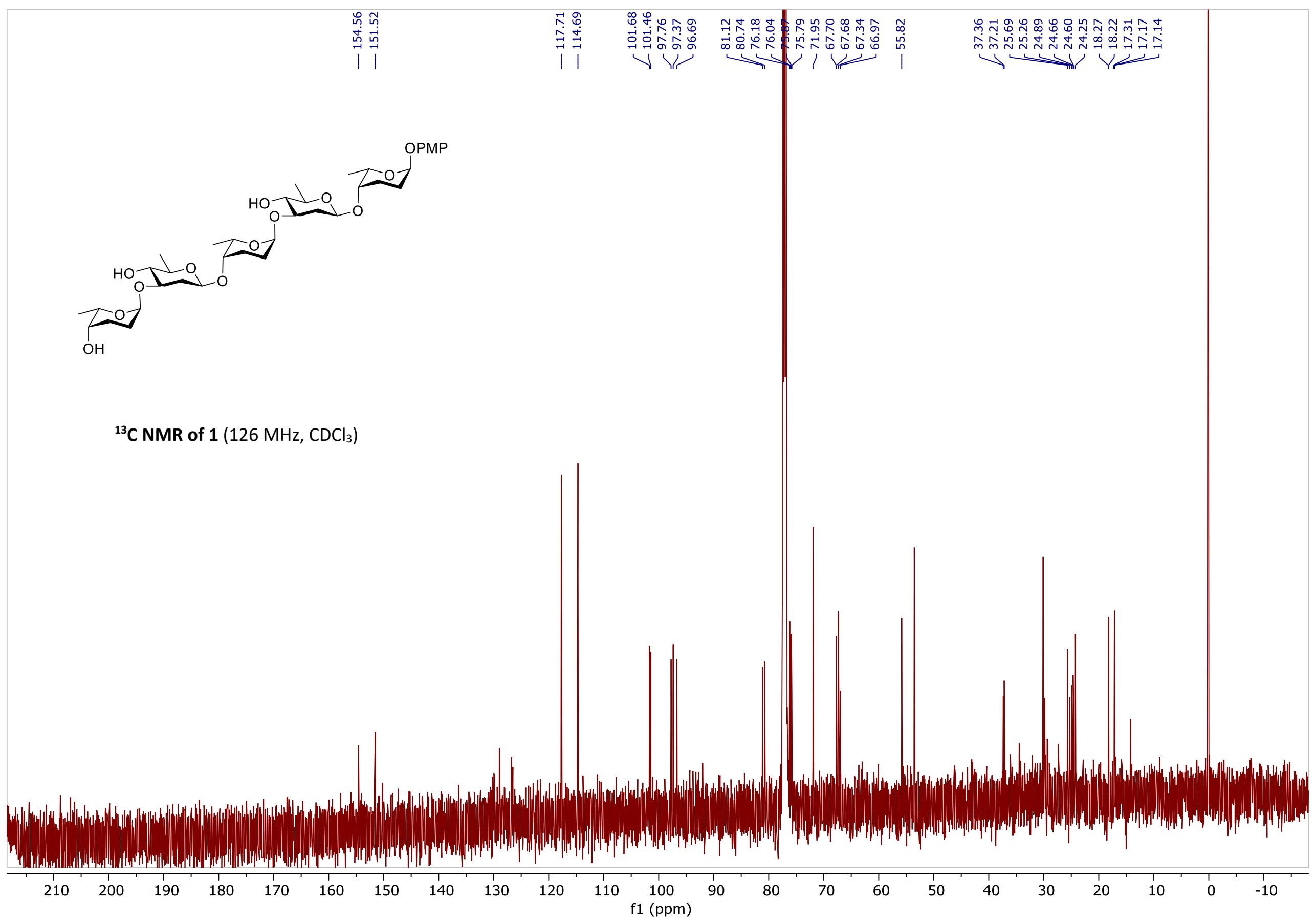


HSQC of $1\left(500 \mathrm{MHz}, \mathrm{CDCl}_{3}\right)$

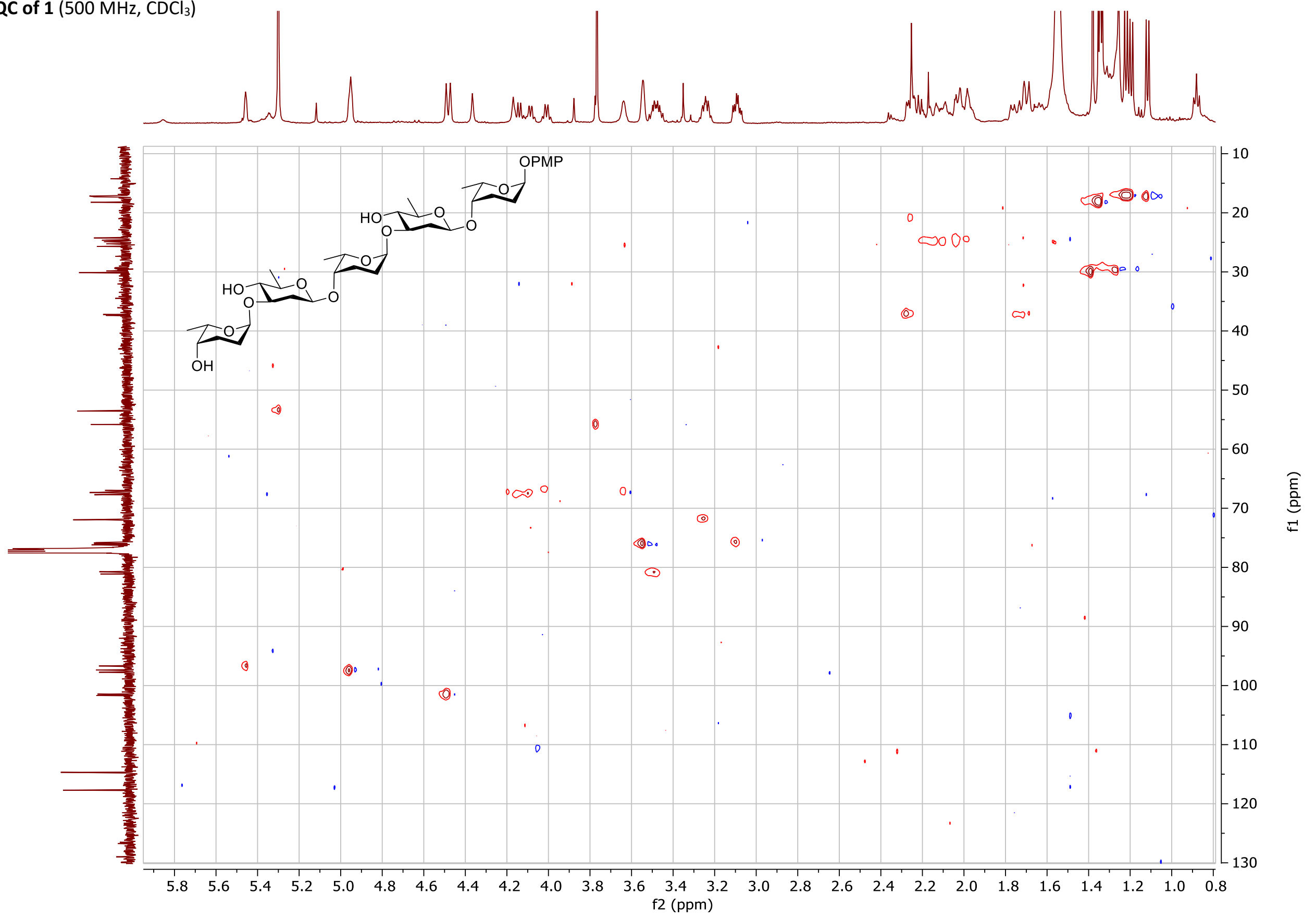




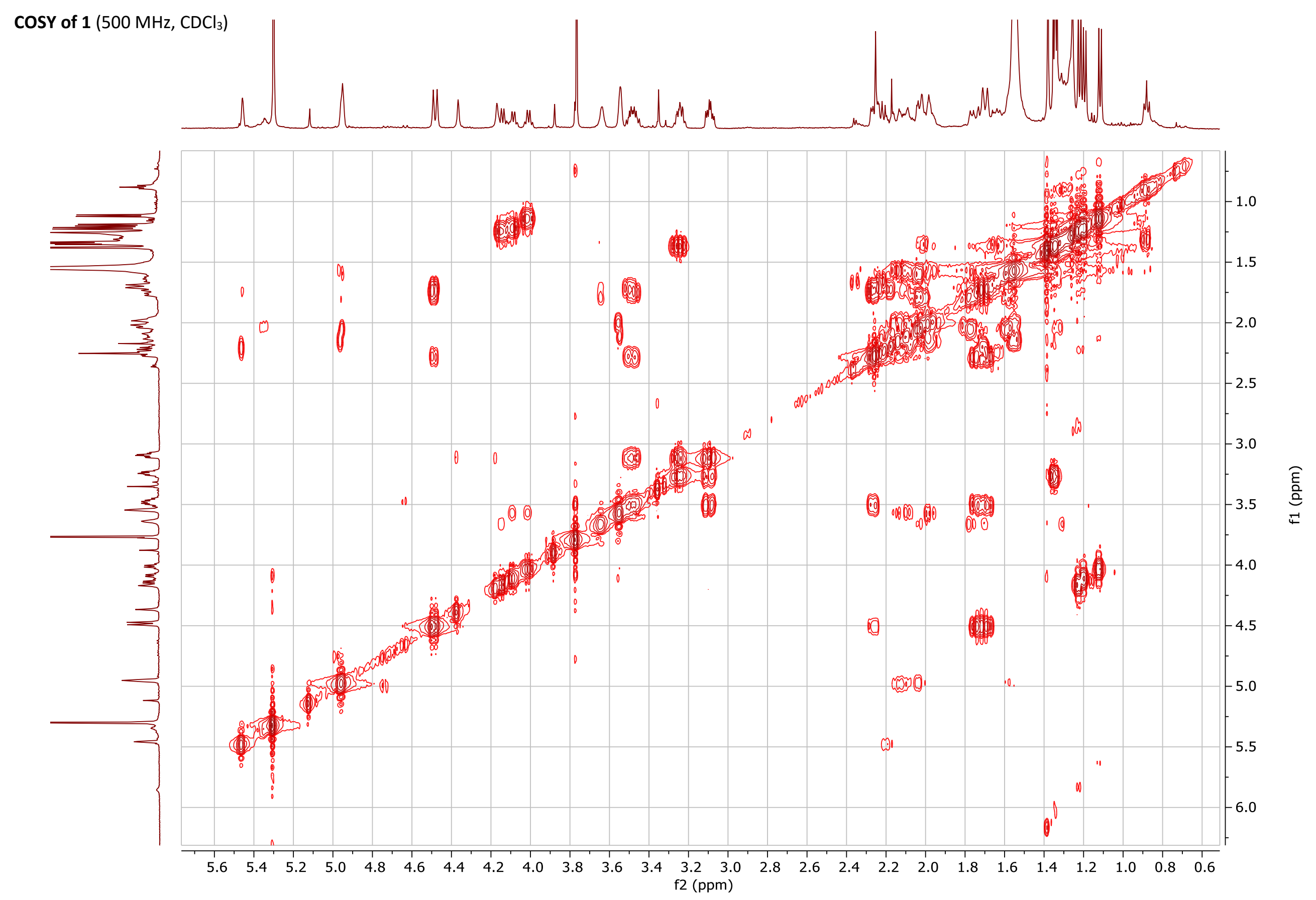

